\title{
CARCINOMA VERRUCOSO DE BOCA: ANÁLISE DAS CARACTERÍSTICAS CLÍNICA E MICROSCÓPICA, DA EXPRESSÃO IMUNO-HISTOQUÍMICA E DA HIPERMETILAÇÃO DO GENE DA E-CADERINA
}

RENATO VIEIRA DE MORAES

Dissertação apresentada à Faculdade de Odontologia de Bauru, Universidade de São Paulo, como parte dos requisitos para obtenção do título de Mestre em Odontologia, área de Patologia Bucal.

(Edição Revisada)

\section{BAURU}




\section{CARCINOMA VERRUCOSO DE BOCA: ANÁLISE DAS CARACTERÍSTICAS CLÍNICA E MICROSCÓPICA, DA EXPRESSÃO IMUNO-HISTOQUÍMICA E DA HIPERMETILAÇÃO DO GENE DA E-CADERINA}

RENATO VIEIRA DE MORAES

Dissertação apresentada à Faculdade de Odontologia de Bauru, Universidade de São Paulo, como parte dos requisitos para obtenção do título de Mestre em Odontologia, área de Patologia Bucal.

Orientadora: Prof. ${ }^{a}$ Dr. ${ }^{a}$ Denise Tostes Oliveira

(Edição Revisada)

\section{BAURU}




\begin{tabular}{|c|c|}
\hline & Moraes, Renato Vieira de \\
\hline \multirow[t]{7}{*}{ M791c } & Carcinoma verrucoso de boca: análise das características clínica e \\
\hline & microscópica, da expressão imuno-histoquímica e da hipermetilação do gene da \\
\hline & E-caderina / Renato Vieira de Moraes.--Bauru, 2005. \\
\hline & xxv, 137p.: il.; 30cm. \\
\hline & Dissertação. (Mestrado)--Faculdade de Odontologia de Bauru. Universidade \\
\hline & de São Paulo. \\
\hline & Orientadora: Prof. ${ }^{\text {a }}$ Dr. ${ }^{\text {a }}$ Denise Tostes Oliveira \\
\hline
\end{tabular}

Autorizo, exclusivamente para fins acadêmico e científico, a reprodução total ou parcial desta dissertação por processos fotocopiadores e/ ou meios eletrônicos.

Assinatura do autor:

Data: Bauru, 17 de fevereiro de 2005.

Projeto de pesquisa aprovado pela Comissão de Ética em Pesquisa do Hospital do Câncer AC Camargo- número 480/03, em reunião de 29 de março de 2003. 


\section{RENATO VIEIRA DE MORAES}

22 de dezembro de $1977 \quad$ Nascimento

Tatuí/ SP

Filiação

Moacir Benedito Corrêa de Moraes

Benedita Vieira de Moraes

1996-1999

Curso de Graduação em Odontologia pela Faculdade de Odontologia de Araçatuba - Universidade Estadual Paulista

2001-2002

Curso de Especialização em Endodontia pela Faculdade de Odontologia de Araçatuba - Universidade Estadual Paulista

2003-2005

Mestrado em Patologia Bucal pela Faculdade de Odontologia de Bauru - Universidade de São Paulo 
"É melhor tentar e falhar, que preocupar-se e ver a vida passar;

É melhor tentar, ainda em vão, que sentar-se fazendo nada até o final;

Eu prefiro na chuva caminhar, que em dias tristes em casa me esconder;

Prefiro ser feliz, embora louco, que em conformidade viver..."

Martin Luther King 


\section{DEDICATÓRIA}

Aos meus pais Moacir e Benedita,

pelo carinho, retidão e incentivos constantes.

Minha eterna gratidão! 
À minha orientadora Prof. ${ }^{a}$ Dr. ${ }^{a}$ Denise Tostes Oliveira, agradeço a confiança em mim depositada e a oportunidade da realização deste trabalho. Agradeço os ensinamentos transmitidos, que me proporcionaram enriquecimento profissional, intelectual e pessoal, bem como a amizade cultivada.

Minha sincera gratidão! 
Ao Prof. Dr. Gilles Landman, sou grato pelas críticas, sugestões e ensinamentos que enriqueceram este trabalho. Agradeço também a possibilidade e a confiança depositada.

Ao Prof. Dr. Luiz Paulo Kowalski, um especial agradecimento ao incentivo constante e pela atenção, presteza e disposição a mim sempre dispensadas. 
Ao Prof. Dr. Alberto Consolaro, coordenador dos Cursos de Pós-Graduação em Patologia Bucal da Faculdade de Odontologia de Bauru-USP, agradeço a oportunidade de cursar este mestrado e a disponibilidade financeira para aquisição dos reagentes utilizados neste trabalho. Minha admiração e sincera gratidão. 


\section{AGRADECIMESTOS ESPECIAIS}

A Deus, pois sem Ele nada do que foi feito se faria.

Aos meus irmãos Fabian, Adriano e Patrícia, minha cunhada Simone e meu sobrinho Diego que, com os seus auxílios e contribuições, permitiram a realização deste curso de mestrado. Obrigado por tudo que vocês fizeram por mim!

Ao Prof. Dr. Raul Negrão Fleury e sua esposa Margarida, pelo incentivo e pela acolfida em Bauru.

Ao Sr. Celso e sua esposa Sueli, Rodrigo e sua esposa Gislaine, pelo incentivo e apoio durante todo esse processo de crescimento profissional, intelectual e pessoal.

À Giseli, pelo incentivo, compreensão e carinho. Obrigado por ser maravilhosa e fazer parte da minha vida. 


\section{AGRADECIMENTOS}

Aos professores da Disciplina de Patologia Bucal da Faculdade de Odontologia de Bauru Prof. Dr. Alberto Consolaro, Prof. ${ }^{a}$ Dr. ${ }^{a}$ Denise Tostes Oliveira, Prof. ${ }^{a}$ Dr. $^{a}$ Vanessa Soares Lara e Prof. Dr. Luís Antônio de Assis Taveira, mestres e amigos, cujos ensinamentos nortearão minha vida profissional.

Aos funcionários da Disciplina de Patologia Bucal da Faculdade de Odontologia de Bauru Cristina, Oziel, Valdir e, de modo especial, à Fatiminha pela confecção dos cortes microscópicos. Meu sincero agradecimento por tudo que fizeram. Vocês são especiais!

Aos meus colegas de turma Bethânia, Camila, Luciana, Renata Falchete, Renata Consolaro e Tiago por todos os momentos desfrutados e pela constante manifestação de amizade.

Aos demais pós-graduandos da Patologia Bucal da FOB-USP Ana Carolina, Carlos, Érika Martins, Érika Sinara, Erick, Janaína, Leda, Marta, Patrícia, Rosário, Simone e Suzana por todas as experiências vivenciadas.

Aos "antigos"pós-graduandos da Patologia Bucal da FOB-USP Aline, Andrea, João Adolfo, Lídia, Maria Fernanda, Maria Renata, Rosa, Tânia e Valdomiro, pelos momentos desfrutados.

À Dr. $^{a}$ Fernanda Costa Grizzo de Sampaio Góes pelos conselhos, disponibilidade e auxílio que foram fundamentais para a realização deste trabalho. 
À Prof. ${ }^{a} \operatorname{Dr}^{a}{ }^{a}$ Inês $\mathcal{N}$ obuko $\mathcal{N}$ ishimoto pela realização e orientação da estatística deste trabalho e pelas críticas construtivas.

À química e farmacêutica Suely Nonogaki, do Setor de Imuno-histoquímica em Pesquisa do Centro de Pesquisa do Hospital da Câncer A.C. Camargo, pela segura orientação nas reações imuno-histoquímicas e pelas sugestões apresentadas.

Ao Prof. Dr. André Vettore e, de modo especial, à Prof. ${ }^{a}$ Dr. ${ }^{a}$ Otávia Caballero, pela oportunidade de desenvolver parte do meu projeto de mestrado no Laboratório de Genética do Câncer $(\mathcal{L} G \mathcal{N} C)$ do Instituto Ludwig de Pesquisa sobre o Câncer e pelas importantes sugestões que enriqueceram este trabalho.

Ao Prof. Valdir João Afonso pela correção do vernáculo.

Ao Prof. Dr. Fernando Augusto Soares, chefe do Departamento de Anatomia Patológica do Hospital do Câncer A.C. Camargo, pela oportunidade e prontidão com que sempre me atendeu.

Ao Dr. Humberto Torloni, pela oportunidade e concessão dos recursos do Instituto Ludwig de Pesquisa sobre o Câncer.

Ao Prof. Dr. Eloi Dezan Júnior, pelo incentivo e pela amizade cultivada.

À bibliotecária Maria Helena Ronchesel pela correção e normatização técnica deste trabalho.

À doutoranda Marta Miyazawa pelo auxílio na captura das imagens e amizade. 
A todos os funcionários da Biblioteca da Faculdade de Odontologia de Bauru, em nome de Cybelle de Assumpção Fontes, pelo auxílio e orientações no transcorrer do curso.

A todos os funcionários da Secretaria de Pós-graduação da Faculdade de Odontologia de Bauru, em especial a Giane Tenório Quintela, pela prontidão com que sempre me atenderam.

Aos funcionários do Laboratório de Anatomia Patológica do Hospital do Câncer A.C. Camargo César, Carlinhos, Severino e Fabiana pela confecção dos cortes microscópicos.

Aos funcionários do Arquivo da Anatomia Patológica do Hospital do Câncer A.C. Camargo Glauber e Marcelo pela assistência e prontidão dispensados.

A todos os funcionários da Secretaria do Departamento de Anatomia Patológica do Hospital do Câncer A.C. Camargo, pela gentileza sempre dispensada.

A todos os funcionários do Serviço de Arquivo Médico do Hospital do Câncer A.C. Camargo, em especial a Sra. Hirde Contesini, pela disponibilidade e presteza com que sempre me atenderam.

Aos amigos do Laboratório de Genética do Câncer (LGSC), Adriana, Adriane, Andréia, Daniel, Fábio, Luciane, Maria Isabel e Valéria Paixão pelo apoio e constante manifestação de amizade.

Ao biólogo Fabrício de Carvalho pela dedicação, paciência, apoio e ensinamentos dispensados que foram fundamentais para a realização deste trabalho. 
Aos amigos do Departamento de Estomatologia do Hospital do Câncer A.C. Camargo, Prof. Dr. Fábio, Divaldo, Ana Laura, Daniel, Graziella, Juliana, Mariana e Ricardo pela amizade cultivada.

Aos funcionários do Departamento de Estomatologia do Hospital do Câncer A.C. Camargo, Luciele e Juscelino pela prontidão que sempre me atenderam.

Aos amigos Alex e João Adolfo pela amizade verdadeira e apoio constante.

Aos amigos Marcelo, Márcio, Renato e Rodrigo pela amizade, pelos momentos de descontração e acolhida em São Paulo. 


\section{AGRADECIMENTOS ISSTITUCIONAIS}

À Direção da Faculdade de Odontologia de Bauru, Vniversidade de São Paulo, na pessoa da Diretora Prof. ${ }^{a}$ Dr. ${ }^{a}$ Maria Fidela de Lima Savarro.

À Comissão de Pós-graduação da Faculdade de Odontologia de Bauru, na pessoa do Presidente Prof. Dr. José Carlos Pereira.

Ao Coordenador dos Cursos de Pós-graduação em Patologia Bucal da Faculdade de Odontologia de Bauru Prof. Dr. Al6erto Consolaro.

À Direção do Hospital do Câncer A.C. Camargo e do Instituto Ludwig de Pesquisa sobre o Câncer, na pessoa do Diretor Prof. Dr. Ricardo Renzo Brentani.

À CAPES, pelo auxílio pecuniário. 


\section{SUMÁRIO}

LISTA DE FIGURAS $\quad$ xvi

LISTA DE TABELAS $\quad$ xviii

LISTA DE ABREVIATURAS E SÍMBOLOS Xxi

RESUMO $\quad$ XXV

1 INTRODUÇÃO 1

2 REVISÃO DA LITERATURA 5

$\begin{array}{lll}2.1 & \text { Carcinoma verrucoso de boca }\end{array}$

2.1.1 Características clínica e microscópica 6

2.1.2 Etiologia 8

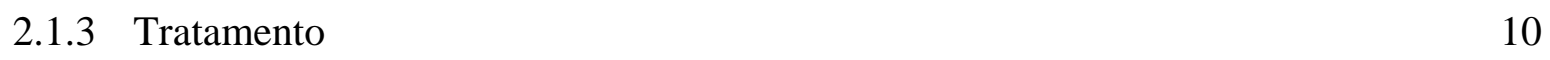

2.1.4 Aspecto histórico $\quad 12$

2.2 Molécula de adesão celular E-caderina: importância no desenvolvimento e $\begin{array}{ll}\text { evolução dos carcinomas espinocelulares } & 14\end{array}$

2.3 Hipermetilação da região promotora do gene da E-caderina em carcinomas espinocelulares

3 PROPOSIÇÃO

$4 \quad$ MATERIAL E MÉTODOS 37

4.1 População de estudo e seleção da amostra 38

4.2 Registro dos dados clínicos e microscópicos 39

4.3 Variáveis de estudo 40

4.4 Análise da hipermetilação do gene da E-caderina nos carcinomas bucais 42

4.4.1 Extração de DNA $\quad 42$

4.4.2 Tratamento com bissulfito de sódio e PCR (MSP) 45 
4.5 Método imuno-histoquímico 51

4.6 Avaliação imuno-histoquímica 53

4.7 Análise estatística $\quad 54$

4.8 Registro fotográfico 55

4.9 Questões éticas 55

5 RESULTADOS 56

5.1 Carcinoma verrucoso 57

5.1.1 Casuística 57

5.1.2 Caracterização demográfica e clínica da população de estudo 58

5.1.3 Análise microscópica morfológica 63

5.2 Análise da hipermetilação do gene da E-caderina nos carcinomas verrucosos e $\begin{array}{ll}\text { espinocelulares bem diferenciados de boca } & 68\end{array}$

5.3 Análise da expressão imuno-histoquímica da E-caderina nos carcinomas $\begin{array}{ll}\text { verrucosos e espinocelulares de boca } & 77\end{array}$

5.4 Correlação da expressão imuno-histoquímica e a hipermetilação do gene da E$\begin{array}{ll}\text { caderina nos carcinomas bucais } & 87\end{array}$

5.5 Análise de sobrevida $\quad 89$

6 DISCUSSÃO 94

7 CONCLUSÕES 114

$\begin{array}{ll}\text { ANEXO } & 119\end{array}$

REFERÊNCIAS BIBLIOGRÁFICAS 123

$\begin{array}{ll}\text { ABSTRACT } & 136\end{array}$

APÊNDICE 


\section{LISTA DE FIGURAS}

FIGURA 1- Representação esquemática das alterações moleculares da E-caderina durante a progressão tumoral. Adaptada de ZIOBER et al. ${ }^{101}, 2001$

FIGURA 2- Representação esquemática do tratamento do DNA com o reagente bissulfito de sódio. Adaptada de $\operatorname{COSTA}^{22}, 2004$

FIGURA 3- A e B - CV bucal com intensa queratinização na superfície verrucosa, cristas epiteliais arredondadas, padrão compressivo e discreto infiltrado inflamatório no tecido conjuntivo. (HE, aumento original $\mathrm{A}$ e $\mathrm{B}=40 \mathrm{X}$ )

FIGURA 4- CV bucal com discreto pleomorfismo celular, poucas figuras de mitoses e infiltrado inflamatório mononuclear subepitelial (A). Em B nota-se membrana basal íntegra na interface epitélio-conjuntivo. (HE, aumento original $\mathrm{A}$ e $\mathrm{B}=400 \mathrm{X})$

FIGURA 5- $\quad \mathrm{CV}$ bucal com intenso infiltrado inflamatório polimorfonucleares na superfície queratinizada (A). Em B, observa-se células inflamatórias crônicas invadindo e desorganizando a camada basal do epitélio. (HE, aumento original $\mathrm{A}=200 \mathrm{X}$ e $\mathrm{B}=400 \mathrm{X}$ )

FIGURA 6- Gel de poliacrilamida 8\% contendo reações de MSP com cinco amostras de carcinoma verrucoso (CV) e cinco amostras de carcinoma espinocelular bem diferenciado sem comprometimento linfonodal (CECpN0). MM - marcador de peso molecular 100pb, U: situação não metilada (97pb), Mt: situação metilada (115pb). Perfil de metilação: não metilada, + metilada

FIGURA 7- Gel de poliacrilamida 8\% contendo reações de MSP com cinco amostras de carcinoma espinocelular bem diferenciado com comprometimento linfonodal (CEC-pN+) e duas amostras de hiperplasia fibrosa (HF). Dois controles utilizados: um para a situação metilada (H 1299) e um para a situação não metilada (MCF-7). MM: marcador de peso molecular 100pb, No: controle sem DNA, U: situação não metilada (97pb), Mt: situação metilada (115pb). Perfil de metilação: - não metilada, + metilada 
FIGURA 8- Imunopositividade à E-caderina na mucosa bucal normal (A). Em B, expressão membranosa completa da E-caderina no $\mathrm{CV}$ bucal. (IMH, aumento original $\mathrm{A}$ e $\mathrm{B}=400 \mathrm{X}$ )

FIGURA 9- Redução da expressão membranosa completa da E-caderina nas ilhotas epiteliais do CEC bem diferenciado (A). Em B, observa-se no CV bucal a forte expressão na crista epitelial e uma redução desta expressão na região da camada basal do epitélio $(\mathrm{B})$. ( $\mathrm{IMH}$, aumento original $\mathrm{A}$ e $\mathrm{B}=$ 400X)

FIGURA 10- Sobrevida global dos pacientes com carcinoma verrucoso (CV), carcinomas espinocelulares bem diferenciados sem comprometimento linfonodal (CEC-pN0) e com comprometimento linfonodal (CEC-pN+). Porcentagem de sobrevida acumulada pela técnica de Kaplan-Meier

FIGURA 11- Sobrevida livre de doença dos pacientes com carcinoma verrucoso (CV), carcinomas espinocelulares bem diferenciados sem comprometimento linfonodal (CEC-pN0) e com comprometimento linfonodal (CEC-pN+). Porcentagem de sobrevida acumulada pela técnica de Kaplan-Meier 


\section{LISTA DE TABELAS}

TABELA 1- Distribuição dos carcinomas verrucosos e carcinomas espinocelulares de boca quanto aos critérios de inclusão estabelecidos. Hospital do Câncer, São Paulo, 1980 a 2000

TABELA 2- Distribuição de freqüência dos pacientes acometidos pelo carcinoma verrucoso de boca segundo as características demográficas e localização da lesão. Hospital do Câncer, São Paulo, 1980 a 2000

TABELA 3- Distribuição de freqüência dos pacientes acometidos pelo carcinoma verrucoso de boca segundo os fatores de risco e a história clínica. Hospital do Câncer, São Paulo, 1980 a 2000

TABELA 4- Distribuição de freqüência dos pacientes acometidos pelo carcinoma verrucoso de boca, segundo as características clínicas da lesão e o estadiamento clínico. Hospital do Câncer, São Paulo, 1980 a 2000

TABELA 5- Distribuição de freqüência dos pacientes acometidos pelo carcinoma verrucoso de boca, segundo o tratamento e a evolução clínica. Hospital do Câncer, São Paulo, 1980 a 2000

TABELA 6- Distribuição de freqüência dos pacientes acometidos pelo carcinoma verrucoso de boca, segundo as características microscópicas. Hospital do Câncer, São Paulo, 1980 a 2000

TABELA 7- Perfil da metilação do gene da E-caderina nos carcinomas verrucosos e carcinomas espinocelulares bem diferenciados de boca. Hospital do Câncer, São Paulo, 1980 a 2000

TABELA 8- Distribuição de freqüência da hipermetilação do gene da E-caderina segundo as características clínicas dos três grupos de carcinomas de boca. Hospital do Câncer, São Paulo, 1980 a 2000

TABELA 9- Distribuição de freqüência da hipermetilação do gene da E-caderina segundo as características clínicas dos três grupos de carcinomas de boca. Hospital do Câncer, São Paulo, 1980 a 2000 
TABELA 10- Distribuição de freqüência da hipermetilação do gene da E-caderina segundo as características clínicas dos três grupos de carcinomas de boca. Hospital do Câncer, São Paulo, 1980 a 2000

TABELA 11- Distribuição da expressão imuno-histoquímica do anticorpo E-caderina nos carcinomas verrucosos e carcinomas espinocelulares bem diferenciados de boca. Hospital do Câncer, São Paulo, 1980 a 2000

TABELA 12- Distribuição da expressão imuno-histoquímica do anticorpo E-caderina nos carcinomas verrucosos e carcinomas espinocelulares bem diferenciados de boca. Hospital do Câncer, São Paulo, 1980 a 2000

TABELA 13- Distribuição de freqüência da expressão imuno-histoquímica da Ecaderina segundo as características clínicas dos três grupos de carcinomas de boca. Hospital do Câncer, São Paulo, 1980 a 2000

TABELA 14- Distribuição de freqüência da expressão imuno-histoquímica da Ecaderina segundo as características clínicas dos três grupos de carcinomas de boca. Hospital do Câncer, São Paulo, 1980 a 2000

TABELA 15- Distribuição de freqüência da expressão imuno-histoquímica da Ecaderina segundo as características clínicas dos três grupos de carcinomas de boca. Hospital do Câncer, São Paulo, 1980 a 2000

TABELA 16- Distribuição do perfil de metilação do gene da E-caderina em relação à expressão imuno-histoquímica da E-caderina nos carcinomas verrucosos e carcinomas espinocelulares bem diferenciados de boca. Hospital do Câncer, São Paulo, 1980 a 2000

TABELA 17- Correlação entre os valores de $p$ e os grupos de carcinomas de boca, agrupados $2 \times 2$, quanto à expressão imuno-histoquímica e o perfil de metilação do gene da E-caderina. Hospital do Câncer, São Paulo, 1980 a 2000

TABELA 18- Análise de sobrevida global e sobrevida livre de doença dos pacientes com carcinomas verrucosos e espinocelulares de boca

Probabilidade de sobrevida acumulada pela técnica de Kaplan-Meier 
TABELA 19- Análise de sobrevida global dos três grupos de carcinomas de boca em relação a imuno-histoquímica e o perfil de metilação do gene da Ecaderina

Probabilidade de sobrevida acumulada pela técnica de Kaplan-Meier

TABELA 20- Análise de sobrevida livre de doença dos três grupos de carcinomas de boca em relação a imuno-histoquímica e o perfil de metilação do gene da E-caderina

Probabilidade de sobrevida acumulada pela técnica de Kaplan-Meier 


\section{LISTA DE ABREVIATURAS E SÍMBOLOS}

$\alpha:$ alfa

$\beta$ : beta

$\gamma$ : gama

$\delta$ : delta

$\mu \mathrm{L}:$ microlitro

$\mu \mathrm{m}$ : micrometro

$\mu \mathrm{M}$ : micromol

000: vivo livre de doença

${ }^{\circ} \mathrm{C}$ : grau centígrado

AC: Antônio Cândido

BSA: albumina sérica bovina

CAM: molécula de adesão celular

CEC: carcinoma espinocelular

CEC-pN0: carcinoma espinocelular bem diferenciado sem comprometimento linfonodal CEC-pN+: carcinoma espinocelular bem diferenciado com comprometimento linfonodal CEP: comissão de ética em pesquisa

C: citosina

$\mathrm{cm}$ : centímetro

$\mathrm{CV}$ : carcinoma verrucoso

DAB: diaminobenzidine tetrahydrochloride

DMSO: dimetilsulfóxido

DNMT: DNA metiltransferase

DNTPs: Deoxinucleotídeos fosfato

DNA: ácido desoxirribonucléico

E-box: região específica da região promotora do gene da E-caderina

EBV: Epstein-Barr vírus

E-cad: E-caderina

E-caderina: caderina epitelial

EGF: fator de crescimento epitelial 
EGFR: receptor do fator de crescimento epitelial

EMT: transição epitélio-mesênquima

ER: receptor de estrógeno

EUA: Estados Unidos da América

G: guanina

HDAC: histona deacetilase

$\mathrm{H}_{2} \mathrm{O}_{2}$ : peróxido de hidrogênio

HE: hematoxilina e eosina

HPV: Human Papilloma virus

IMH: imuno-histoquímica

kDa: kilodalton

LOH: perda de heterozigose

$\mathrm{mL}$ : mililitro

mM: milimol

M: solução molar

Mt: methylated

MBC: marcação membranosa completa

MBPs: methyl binding proteins

MeCP: methyl cytosine binding proteins

$\mathrm{MgCl}_{2}$ : cloreto de magnésio

MM: marcador de peso molecular

$\mathrm{MN}$ : mononucleares

MOASS: morte sem evidência de recidiva do tumor primário

MOCA: morte decorrente do tumor primário

MOCI: morte por intercorrência cirúrgica

MSP: methylation specific PCR

mRNA: messenger ribonucleic acid

$\mathrm{N}+$ : presença de linfonodos regionais palpáveis

N0: ausência de linfonodos regionais palpáveis

N1: metástase em um único linfonodo homolateral, com $3 \mathrm{~cm}$ ou menos em seu maior diâmetro, segundo a classificação TNM para tumores malignos de boca 
N2: metástase em um único linfonodo homolateral, com mais de $3 \mathrm{~cm}$ ou até $6 \mathrm{~cm}$ em seu maior diâmetro, ou em linfonodos homolaterais múltiplos, nenhum deles com mais de $6 \mathrm{~cm}$ em seu maior diâmetro, ou em linfonodos bilaterais ou contralaterais, nenhum deles com mais de $6 \mathrm{~cm}$ em seu maior diâmetro, segundo a classificação TNM para tumores malignos de boca

N3: metástase em linfonodo regional com mais de $6 \mathrm{~cm}$ em seu maior diâmetro, segundo a classificação TNM para tumores malignos de boca

$\mathrm{N}$-caderina: caderina neural

NCDB: National Cancer Data Base

OMS: Organização Mundial da Saúde

PMN: polimorfonucleares

PAS: periodic acid Schiff

pb: pares de bases nitrogenadas

PBS: phosphate buffered saline

P-caderina: caderina placentária

PCR: reação em cadeia da polimerase

$\mathrm{pH}$ : concentração hidrogeniônica

$\mathrm{pN}+$ : presença de metástase em linfonodos regionais confirmada microscopicamente

pN0: ausência de metástase em linfonodos regionais confirmada microscopicamente

rpm: rotação por minuto

SIP-1: Smad-interacting protein

$\delta$ EF1/ZEB1: $\delta$ crystallin enhancer binding factor/ zinc finger $E$ box binding protein 1

snail: zinc finger transcription factor

SAME: serviço de arquivo médico

StreptABComplex: streptavidin and biotinylated peroxidase complex

T1: tumor com até $2 \mathrm{~cm}$ em sua maior extensão, segundo a classificação TNM para tumores malignos de boca

T2: tumor com mais de $2 \mathrm{~cm}$ e até $4 \mathrm{~cm}$ em sua maior extensão, segundo a classificação TNM para tumores malignos de boca

T3: tumor com mais de $4 \mathrm{~cm}$ em sua maior extensão, segundo a classificação TNM para tumores malignos de boca 
T4: tumor com mais de 4cm em sua maior extensão, invadindo estruturas adjacentes, segundo a classificação TNM para tumores malignos de boca

TNM: classificação dos tumores malignos ("Tumor Node Metastasis”)

u: unidade

$\mathrm{U}$ : unmethylated

UICC: União Internacional Contra o Câncer 


\section{RESUMO}

O carcinoma verrucoso (CV), é considerado uma variante do carcinoma espinocelular (CEC) bem diferenciado, que se caracteriza por sua baixa agressividade e bom prognóstico e acomete principalmente a laringe e a boca. Um total de 1613 carcinomas espinocelulares primários de boca, cirurgicamente excisados entre 1980 e 2000, foram revisados dos arquivos dos Departamentos de Patologia e Cirurgia de Cabeça e Pescoço e Otorrinolaringologia do Hospital do Câncer A.C. Camargo. Dez CVs foram identificados e analisados quanto ao gênero, idade, raça, tabagismo, etilismo, localização do tumor primário, classificação pelo sistema TNM, tratamento, ocorrência de recidiva tumoral, metástases em linfonodos regionais, a distância e de segundo tumor primário. Analisaram-se também a expressão imuno-histoquímica e a hipermetilação da região promotora do gene da E-caderina, e os valores obtidos foram comparados com carcinomas espinocelulares bem diferenciados de boca sem (CEC-pN0) e com (CEC-pN+) comprometimento linfonodal. As probabilidades de sobrevidas, acumuladas nos períodos de cinco e dez anos para os grupos tumorais, foram calculadas pelo método de Kaplan-Meier. Os resultados demonstraram uma predileção dos CVs por pacientes do gênero masculino, tabagistas e etilistas, com idade superior a 67 anos, ocorrendo principalmente no lábio inferior. O tempo de história clínica foi maior que 16 meses e nenhum paciente com CV foi submetido à radioterapia e/ou quimioterapia pós-operatória. Microscopicamente as lesões eram bem características com intensa queratinização, padrão de invasão compressivo, pouca atipia e margens cirúrgicas livres. Uma maior expressão imunohistoquímica da E-caderina foi verificada nos carcinomas verrucosos quando comparados aos grupos de CEC-pN0 e CEC-pN+, sendo a diferença entre os grupos estatisticamente significativa $(\mathrm{p}=0,016)$. O perfil de metilação do gene da E-caderina foi estatisticamente semelhante $(\mathrm{p}=0,975)$ e superior a $50 \%$ nos três grupos de carcinomas de boca avaliados (CV, CEC-pN0 e CEC-pN+). A sobrevida global do grupo $\mathrm{CV}$ foi superior aos grupos de CECs bem diferenciados tanto em cinco quanto em dez anos $(p=0,012)$. Com base nestes resultados concluímos que o carcinoma verrucoso bucal apresenta um comportamento clínico e biológico relativo à expressão da E-caderina, mais favorável quando comparado carcinoma espinocelular bem diferenciado. A presença da hipermetilação do gene da E-caderina em neoplasias malignas com baixo potencial invasivo e metastático como o $\mathrm{CV}$ sugere que este evento epigenético ocorre precocemente nos mecanismos envolvidos na progressão tumoral. 
1 INTRODUÇÃO 


\section{INTRODUÇÃO}

O carcinoma verrucoso é considerado uma variante distinta do carcinoma espinocelular bem diferenciado ${ }^{1,7,11,12,24,30,46,48,52,56,61,68,70,71,82,100}$ e foi inicialmente identificado e meticulosamente descrito na região bucal por ACKERMAN ${ }^{1}$, em 1948. Apesar de ser um tumor maligno, em sua evolução são observadas algumas características de tumor benigno $^{1,54,70}$.

Localizações como superfícies cutâneas, região anorretal, genitália e extremidade plantar são comumente afetadas pelo carcinoma verrucoso, entretanto, os principais sítios de predileção desta lesão consistem nas membranas mucosas da região de cabeça e pescoço, destacando-se a laringe e a boca ${ }^{11,12,54,61,68}$.

Esta lesão, caracterizada por sua baixa agressividade e bom prognóstico, raramente evolui com metástases regionais, não sendo verificado relatos de disseminação tumoral a distância ${ }^{1,7,11,12,24,30,46,48,52,56,61,68,70,82,100}$.

Clinicamente, apresenta-se com aspecto vegetante em couve-flor, superfície rugosa, sulcada e coloração branco-acinzentada ${ }^{1,7,11,46,52,56,61,68,70,82}$. Devido principalmente ao seu crescimento lento e indolente, esse tumor pode apresentar um tempo de história clínica bastante elevado ${ }^{1,61,70,82}$. Apesar de ser curável em estádios iniciais, pode se tornar localmente agressivo se não tratado e invadir os tecidos adjacentes ${ }^{1,24,54,61,71}$.

Em razão do alto grau de diferenciação celular, o diagnóstico microscópico do carcinoma verrucoso pode gerar dificuldades ${ }^{1,30,31,46,52,54,71,82}$. Microscopicamente, este tumor caracteriza-se por uma proliferação epitelial exofítica com acentuada queratinização 
preenchendo as fendas epiteliais arredondadas que exibem pouca atipia. As margens da lesão apresentam um padrão de invasão compressivo causando destruição do tecido conjuntivo adjacente e a membrana basal permanece intacta ${ }^{1,30,31,46,52,54,61,71,82}$.

Um diagnóstico seguro e confiável do carcinoma verrucoso requer uma biopsia adequada bem como, uma cuidadosa avaliação microscópica por parte do patologista ${ }^{7,30,31,54,82}$. Focos de carcinomas espinocelulares podem ocorrer, simultaneamente, aos carcinomas verrucosos, originando certa confusão na literatura quanto aos critérios para o diagnóstico desta lesão $0^{30,31,36,54,65}$.

Muitas controvérsias persistem na literatura quanto ao tratamento de escolha para o carcinoma verrucoso. A maioria dos pacientes é tratada cirurgicamente ${ }^{54,69,70,82}$, mas a radioterapia ${ }^{48,54,90,100}$ e/ou a quimioterapia ${ }^{69,100}$ também têm sido utilizadas.

No Brasil, poucas análises do carcinoma verrucoso em boca foram encontradas $^{10,20,32,75}$ e a maioria era relativa a descrições de $\operatorname{casos}_{\text {clínicos }}{ }^{10,20,32}$.

Um aspecto intrigante em relação ao comportamento biológico do carcinoma verrucoso refere-se ao seu baixo potencial de invasão e ausência de metástases ${ }^{1 \text {, }}$ $7,11,12,24,46,48,52,54,56,61,68,70,71,82,100$

Alguns estudos demonstraram que as alterações nas moléculas de adesão celular nos carcinomas espinocelulares $3,6,16,39,43,93,95,101$, principalmente aquelas associadas à Ecaderina $^{49,62,73,76,77,79,94,96}$, são requisitos fundamentais para o processo de invasão e metástase, determinando um comportamento biológico mais agressivo e uma evolução clínica desfavorável para estes tumores.

As alterações moleculares que podem levar à perda ou redução da expressão da Ecaderina, em carcinomas espinocelulares de boca, têm sido investigadas ${ }^{14,15,19,49,57,64,91,97,98}$. Recentemente, os eventos epigenéticos, principalmente a hipermetilação da região promotora 
do gene da E-caderina, foi verificada por alguns autores ${ }^{14,15,41,57,64,91,97}$ e uma provável relação entre as amostras que estavam hipermetiladas e a perda ou redução da expressão imunohistoquímica desta molécula de adesão foi observada ${ }^{14,57,64,97}$.

Quanto à expressão imuno-histoquímica da E-caderina em carcinomas verrucosos de boca, apenas dois trabalhos recentemente publicados foram encontrados na literatura científica $^{87,88}$. Já em relação a hipermetilação da região promotora do gene que codifica esta molécula de adesão, nenhum relato foi encontrado.

Portanto, o objetivo deste trabalho consiste em analisar, retrospectivamente, os carcinomas verrucosos de boca no que se refere às características clínicas, histopatológicas, evolução e formas de tratamento. Avaliaremos também a expressão e o perfil de metilação do gene da E-caderina e os resultados obtidos serão comparados com carcinomas espinocelulares bem diferenciados de boca. 
2 REVISÃO DA LITERATURA 


\section{REVISÃO DA LITERATURA}

\subsection{Carcinoma verrucoso de boca}

\subsubsection{Características clínica e microscópica}

O carcinoma verrucoso de boca, descrito inicialmente por ACKERMAN ${ }^{1}$ em 1948, constitui uma variante distinta do carcinoma espinocelular caracterizada por sua baixa agressividade e bom prognóstico ${ }^{1,7,11,12,24,30,46,48,52,56,61,68,70,82,100}$.

Algumas localizações como superfícies cutâneas, região anorretal, genitália e extremidade plantar são comumente afetadas pelo carcinoma verrucoso, entretanto, os principais sítios de predileção desta lesão consistem nas membranas mucosas da região de cabeça e pescoço, destacando-se a laringe e a boca ${ }^{11,12,54,61,68}$. Dependendo do local acometido, esta lesão já recebeu algumas denominações, como tumor de Buschke-Loewenstein quando na área genital, epitelioma cuniculatum para as lesões da região plantar, carcinoma cutâneo papilomatoso para as de pele e na cavidade bucal como tumor de Ackerman ou papilomatose oral florida ${ }^{59}$. Atualmente existe uma tendência em denominar estas lesões como carcinoma verrucoso e especifica-se a região acometida.

Clinicamente, a lesão apresenta um crescimento lento, com aspecto vegetante em couve-flor, superfície rugosa, sulcada e coloração branco-acinzentada podendo conter áreas eritroplásicas ${ }^{1,7,11,46,52,56,61,68,70,82}$. Embora seja freqüentemente curável nos estágios precoces, esta lesão pode se tornar localmente agressiva se não tratada ${ }^{1,24,54,61,70}$. Devido a infecções 
concomitantes, os linfonodos (principalmente submentonianos e submandibulares) podem se tornar enfartados levando ao diagnóstico equivocado de metástase locorregional ${ }^{1}$.

Microscopicamente, o carcinoma verrucoso caracteriza-se por uma proliferação epitelial exofítica com acentuada queratinização preenchendo as fendas ou criptas, e cristas epiteliais arredondadas que exibem pouca atipia. As margens da lesão apresentam um padrão de invasão compressivo causando destruição do tecido conjuntivo adjacente, atingindo em fases mais avançadas os tecidos musculares, ósseos, glandulares e cartilaginosos. As bordas epiteliais nas regiões profundas são amplas e a membrana basal permanece intacta. Freqüentemente, uma reação inflamatória mononuclear encontra-se presente no tecido conjuntivo adjacente à lesão neoplásica ${ }^{1,30,31,46,52,54,61,71,82}$.

$\mathrm{Na}$ análise das características microscópicas de 426 carcinomas verrucosos de boca realizada por RAJENDRAN et al. $^{71}$, em 1989, verificou-se que 53\% das amostras apresentaram invasão local dos tecidos musculares, ósseos e glandulares, entretanto, a disseminação tumoral a distância não foi detectada.

Com a finalidade de analisar a possibilidade de invasão perineural do carcinoma verrucoso e sua relação com o prognóstico, DEMIAN; BUSHKIN; ECHEVARRIA ${ }^{24}$ avaliaram 15 carcinomas verrucosos dos quais 11 eram de boca, três de laringe e um de útero. Encontrou-se invasão perineural em apenas um caso de boca e nenhuma correlação com o prognóstico foi observada. Segundo os autores este evento pode não representar uma maior agressividade do tumor e sim um caminho menos resistente de invasão tumoral.

Mesmo com suas características microscópicas peculiares, deve-se incluir no diagnóstico diferencial do carcinoma verrucoso algumas lesões epiteliais hiperplásicas benignas como o queratoacantoma, hiperplasia pseudoepiteliomatosa, hiperplasia verrucosa além do carcinoma espinocelular papilar e a leucoplasia verrucosa proliferativa ${ }^{12,46,54,61,68}$. 
A grande maioria dos carcinomas verrucosos é clinicamente distinguível dos carcinomas espinocelulares invasivos devido ao seu crescimento lento, pouca atipia e ausência de metástase, porém, focos de carcinoma espinocelular podem ocorrer, simultaneamente, aos carcinomas verrucosos ${ }^{30,36,54,65}$. Portanto, um diagnóstico seguro e confiável do carcinoma verrucoso requer uma biópsia adequada bem como, uma cuidadosa avaliação microscópica por parte do patologista ${ }^{7,30,31,54,65,82}$.

Uma certa confusão quanto aos critérios para o diagnóstico do carcinoma verrucoso parece existir na literatura, sendo que enquanto alguns autores ${ }^{31}$ utilizam-se de expressões do tipo "carcinoma espinocelular de aspecto verrucoso" em lesões que apresentam áreas com características microscópicas de carcinoma espinocelular bem diferenciado, outros ${ }^{36,65}$ denominam esses tumores como carcinomas híbridos. Segundo ISHIYAMA et al. ${ }^{45}$ esses tumores híbridos seriam carcinomas espinocelulares papilares, portanto, uma correta distinção deve ser feita entre o carcinoma verrucoso e o carcinoma espinocelular bem diferenciado e o carcinoma espinocelular papilar. Essa diferenciação microscópica é de fundamental importância para o tratamento proposto e análise da evolução dos pacientes ${ }^{65}$.

\subsubsection{Etiologia}

A etiologia do carcinoma verrucoso é bastante controvertida. A alta freqüência de mucosa com alterações, como leucoplasia, hiperplasia verrucosa, adjacentes à lesão, e o desenvolvimento de carcinomas a partir de lesões proliferativas verrucosas, reforçam a hipótese de que esta neoplasia pode se desenvolver a partir de um precursor benigno ${ }^{46,54}$.

$\mathrm{Na}$ mucosa bucal, o carcinoma verrucoso tem sido associado com os diferentes carcinógenos do tabaco, destacando-se aqueles relacionados ao tabaco sem fumaça. Sua ocorrência na região jugal, palato e gengiva ou rebordo inferiores correspondem, geralmente, 
às localizações de deposição e contato direto do tabaco ou de seus derivados ${ }^{1,11,12,24,50,54,56,70,82}$. ACKERMAN $^{1}$ correlacionou o hábito de mascar tabaco e carcinoma verrucoso principalmente após os relatos de FRIEDELL e ROSENTHAL ${ }^{34}$ em 1941. Estes autores ${ }^{34}$ reportaram a presença de lesões com características verrucóides em oito pacientes que faziam uso de tabaco sem fumaça.

Em 1971, COHEN; POSWILLO; WOODS ${ }^{18}$ avaliaram os efeitos da deposição de tabaco sem fumaça em "bolsas" cirurgicamente preparadas na mucosa jugal de dez macacos (Macaca irus). Foram realizadas biópsias nos períodos de 1,3,5,6,13,14,16 meses para análise em microscopia de luz e 24,36,42 meses para verificação em microscopia eletrônica. Avaliaram-se também biópsias realizadas nas margens de áreas leucoplásicas ou suspeitas de carcinoma espinocelular de nove pacientes que faziam uso de tabaco sem fumaça num período de 10 a 35 anos. Os autores verificaram para ambos os grupos a presença de hipertrofia celular, com células muito vacuoladas. Verificou-se também, por microscopia eletrônica, que em oito dos dez macacos tratados e em sete dos nove pacientes havia áreas focais de microinvasão celular, mas seu valor como indicador do potencial de invasão não foi demonstrado.

No entanto, MCCOY e WALDRON ${ }^{61}$ ao realizarem um estudo retrospectivo de 49 carcinomas verrucosos de boca, verificaram que dos 20 (41\%) indivíduos usuários do tabaco, apenas nove (18\%) faziam uso do tabaco sem fumaça. Além disso, em 29 indivíduos a lesão não estava associada ao uso do tabaco. Também LINK; KAUGARS; BURNS ${ }^{58}$ ao analisarem 129 carcinomas verrucosos de boca, observaram que apenas dez pacientes $(7,7 \%)$ faziam uso do tabaco. Embora o tabaco seja um dos fatores etiológicos do carcinoma verrucoso, em muitos pacientes não foi possível estabelecer essa associação, pois as lesões também ocorrem em indivíduos que não possuem esse vício ${ }^{7,52,58,61}$. 
Os avanços da biologia molecular permitiram elucidar alguns dos mecanismos de regulação do ciclo celular, estabelecendo-se uma provável relação entre o carcinoma verrucoso e o papilomavírus humano (HPV) $2,25,59,72$.

Atualmente mais de cem tipos de HPV já foram descritos, e são classificados como de alto ou baixo risco de acordo com o potencial de induzir lesões malignas. Os de alto risco, que estão associados a vários tumores malignos incluem os tipos 16, 18, 31, 33 e 35; os tipos 51, 52, 56, 59 e 61 também são encontrados em lesões malignas, porém menos freqüentemente. $^{21}$

NOBLE-TOPHAM et al. ${ }^{66}$ avaliaram por PCR a presença de HPV tipo 16 e 18 em 25 carcinomas verrucosos de boca. Encontrou-se correlação do HPV 16 em um espécime (4\%) e do HPV 18 em nove espécimes (36\%) e de ambos em 1 espécime (4\%).

A infecção pelo HPV de maneira isolada parece não ser fator preponderante nas lesões malignas, principalmente devido à existência deste vírus em epitélios normais ${ }^{21}$. Assim, uma provável atividade viral oportunista associada à ação crônica dos carcinógenos, como o tabaco e o álcool, na patogênese do carcinoma verrucoso tem sido sugerida ${ }^{2,25,59,66,72}$.

\subsubsection{Tratamento}

Desde a descrição inicial de ACKERMAN ${ }^{1}$ até os dias de hoje, muitas controvérsias persistem na literatura quanto ao tratamento de escolha para o carcinoma verrucoso. A maioria dos pacientes é tratada cirurgicamente ${ }^{54,69,70,82}$, mas a radioterapia ${ }^{48,54,90,100}$ e ou a quimioterapia $^{69,100}$ também têm sido utilizadas como tratamento inicial naqueles pacientes considerados inoperáveis devido a lesões extensas ou alterações sistêmicas que comprometem a cirurgia. As opiniões sobre o tratamento radioterápico isoladamente são conflitantes devido ao risco de desenvolvimento de formas mais agressivas de carcinomas espinocelulares ${ }^{24,31,100}$. 
Em uma revisão de literatura sobre a possibilidade de transformação do carcinoma verrucoso em carcinoma espinocelular após radioterapia primária, FERLITO; RINALDO; MANNAR $\AA^{30}$ analisaram 148 espécimes de CV dos quais dez (6,7\%) apresentaram esta alteração. Segundo esses autores existe uma possibilidade relativamente baixa e muitas vezes superestimada na literatura, como no trabalho de DEMIAN; BUSHKIN; ECHEVARRIA ${ }^{24}$ que relataram a possibilidade $(30 \%)$ desta transformação, mas em uma casuística muito baixa (15 espécimes, dos quais 11 eram de boca, três de laringe e um de útero). Nesta mesma revisão, FERLITO; RINALDO; MANNARÀ ${ }^{30}$ observaram que apenas $64(43,2 \%)$ dos 148 pacientes com carcinoma verrucoso analisados apresentaram cura após o emprego da radioterapia, estando de acordo com a teoria proposta por LUNDGREN et al. ${ }^{60}$, em 1986, de que o carcinoma verrucoso é menos sensível à radioterapia do que o carcinoma espinocelular.

Uma análise comparativa da resposta à radioterapia, sobrevida e fatores de prognóstico foi realizada por JYOTHIRMAYI et al. ${ }^{48}$ entre 53 carcinomas verrucosos e carcinomas espinocelulares bem diferenciados da mucosa bucal tratados durante o mesmo período. Dos 42 pacientes com carcinomas verrucosos tratados inicialmente com radioterapia, $76 \%$ apresentaram uma resposta completa e $24 \%$ uma resposta parcial ao tratamento. Nenhum dos 16 pacientes cujos carcinomas verrucosos recorreram após a radioterapia apresentou características de transformação para carcinomas espinocelulares mais agressivos. Os autores concluíram que o carcinoma verrucoso possui uma resposta à radioterapia e taxas de sobrevida livre de doença semelhante ao carcinoma espinocelular bem diferenciado.

Em uma recente análise de uma amostra representativa de 2350 carcinomas verrucosos de boca e laringe diagnosticados no National Cancer Data Base (NCDB), no período de 1985 a 1996 nos Estados Unidos da América, KOCH et al. ${ }^{54}$ verificaram que o tratamento cirúrgico isoladamente foi o mais prevalente $(69,7 \%)$ seguido pela cirurgia 
combinada com a radioterapia (11\%) e apenas radioterapia (10,3\%). Para lesões localizadas em boca, a sobrevida relativa de cinco anos foi de $88,9 \%$ para os pacientes tratados inicialmente com cirurgia e de $57,6 \%$ para aqueles que receberam tratamento cirúrgico combinado com radioterapia. Os autores concluíram que os pacientes com carcinoma verrucoso de boca tratados pela cirurgia tiveram uma melhor sobrevida do que aqueles tratados com radioterapia.

No Brasil, poucas análises do carcinoma verrucoso em boca foram encontradas $^{10,20,32,75}$ e algumas destas, eram relativas a descrições de casos clínicos ${ }^{10,20,32}$. A investigação retrospectiva de aspectos clínico e microscópico de amostras representativas de carcinoma verrucoso de boca poderá trazer importantes contribuições para a etiologia, o tratamento e o prognóstico desta neoplasia neste sítio anatômico.

\subsubsection{Aspecto histórico}

Um aspecto interessante e histórico do carcinoma verrucoso envolveu o expresidente Grover Cleveland dos Estados Unidos no ano de 1893.

Inicialmente é interessante descrever os motivos que na época da ocorrência da lesão levaram a tamanho segredo. Antes de Cleveland ser eleito para o segundo mandato não consecutivo, os Estados Unidos estavam assolados numa grave crise econômica, "Pânico de 93", devido ao Ato de Sherman de $1890^{8,82}$. Segundo esse ato, o governo tinha que comprar 4,5 milhões de onças (onça $=28,35 \mathrm{~g}$ ) de prata anualmente; assim muito dinheiro teve que ser emitido o que diminuiu consideravelmente as reservas em ouro do país ${ }^{8,82}$. Conseqüentemente houve uma inflação rompante, desequilíbrio na balança comercial e mais de 600 bancos faliram. No meio desta crise financeira, em que o governo estava empenhado em derrubar o Ato de Sherman, o presidente Cleveland queixou-se da lesão em seu palato ${ }^{8,82}$. O presidente 
optou em realizar todos os exames e a cirurgia em segredo, descartando a possibilidade de um eventual afastamento do cargo, pois seu grande obstáculo no governo era o vice presidente, Adlai E. Stevenson, que era favorável ao Ato. ${ }^{8,82}$

Clinicamente Cleveland apresentava uma lesão no lado esquerdo do palato duro com superfície rugosa, com aspecto em couve-flor e que apresentava algumas áreas com ulcerações $^{8}$. A lesão media aproximadamente de 2 a $3 \mathrm{~cm}$, estendendo-se da distal do segundo pré-molar até distal do terceiro molar, comprometendo parte do palato mole e não ultrapassava a linha média ${ }^{8}$. Cleveland estava com 56 anos, não se queixava de dor e relatou ter notado a lesão há uns dois meses, fumava com freqüência e bebia ocasionalmente ${ }^{8}$.

A biópsia não foi conclusiva gerando vários diagnósticos (carcinoma, sarcoma, ameloblastoma, osteossarcoma, sífilis, tumor de glândula salivar), optando-se então pela remoção cirúrgica da lesão ${ }^{8}$. Para preservar o sigilo, a cirurgia foi realizada em um iate ${ }^{8}$.

O presidente Cleveland faleceu 15 anos após a cirurgia de complicações pulmonares e gastrintestinais e nenhuma recorrência da lesão removida de seu palato foi relatada ${ }^{8}$.

Muitos conflitos foram gerados em função do diagnóstico final da lesão que acometeu o palato do ex-presidente. A lesão ulcerovegetante do palato poderia ser um tumor maligno ou seria uma lesão inflamatória benigna? Muitos patologistas requisitaram os blocos para revisão, mas tiveram seus pedidos negados pelo "Museu Mütter" onde esse material estava guardado ${ }^{8}$. Somente após a morte do último filho de Cleveland, os blocos foram obtidos pelos Drs. Aponte e Enterline que os revisaram e publicaram suas conclusões no artigo intitulado “The Final Diagnosis of President Cleveland's Lesion”.

Microscopicamente, observaram proliferação epitelial exofítica com acentuada queratinização, algumas pérolas córneas e pouca atipia. Notaram também intensa reação 
inflamatória mononuclear presente no tecido conjuntivo adjacente à lesão e membrana basal $\operatorname{intacta}^{8}$.

Segundo os autores ${ }^{8}$ o diagnóstico mais provável para a lesão que acometeu o palato de Cleveland seria de carcinoma verrucoso. Os dados clínicos, microscópicos, bom prognóstico e a ausência de recorrências estariam de acordo com os critérios estabelecidos por Ackerman $^{8}$. Isso poderia explicar também a confusão diagnóstica quando da realização da biópsia da lesão, pois o diagnóstico de carcinoma verrucoso torna-se difícil quando se executa uma biópsia superficial ${ }^{8,82}$.

\subsection{Molécula de adesão celular E-caderina: importância no desenvolvimento e evolução dos carcinomas espinocelulares}

Um aspecto intrigante em relação ao comportamento biológico do carcinoma verrucoso refere-se ao seu baixo potencial de invasão e ausência de metástases ${ }^{1}$, $7,11,12,24,46,48,52,54,56,61,68,70,71,82,100$. Dentre todas as características dos tumores malignos, talvez a que mais influencie a evolução e o prognóstico da doença seja a presença de metástases ${ }^{13}$. Definida como sendo a presença de células tumorais em outros locais do organismo que não o sítio primário do tumor, a presença de metástases envolve a circulação de células tumorais por vasos sangüíneos e/ou linfáticos ${ }^{3,13}$. A aquisição das características fenotípicas que permitem a invasão tecidual e a formação de metástase resulta da ativação de genes promotores e da inativação de genes supressores de invasão tecidual ${ }^{3,13,17}$.

O processo de invasão tumoral e metástases compreende uma cascata de eventos que incluem as seguintes etapas ${ }^{3}$ :

- crescimento tumoral, invasão e desprendimento de células neoplásicas do tumor primário; 
- movimentação das células tumorais pelos vasos linfáticos e/ou sangüíneos;

- $\quad$ sobrevivência destas células na circulação e interação com as plaquetas;

- adesão das células tumorais em órgãos distantes através de interações com o endotélio vascular e/ou membrana basal subendotelial;

- migração celular no parênquima tecidual do órgão afetado;

- crescimento do tumor no local metastático.

Em carcinomas não invasivos, estes eventos não ocorrem, pois as células individuais estão interconectadas por uma complexa rede de adesão celular ${ }^{76,96}$. Após a identificação e caracterização de moléculas específicas da superfície celular que mediam a adesão célula-célula e célula-matriz extracelular, muitas pesquisas relacionadas ao papel destas moléculas no processo metastático têm sido realizadas $3,4,6,14,15,16,19,38,39,43,49,57,62,64,73,76,77$, $85,86,87,88,95,96,97,99$

Somente a destruição de tais interações pode permitir que células neoplásicas malignas migrem para além do tumor primário. Ao longo deste processo, as células neoplásicas interagem com elementos celulares normais e elementos da matriz do hospedeiro ${ }^{3,4,13,17,38,93}$. Da dinâmica destas interações resulta a metástase; assim, pode-se definir o fenótipo metastático em função da expressão de moléculas envolvidas em adesão célula-célula e adesão célula-matriz extracelular ${ }^{3,4,13,17,38,93}$.

A aquisição de características associadas com a progressão tumoral é uma conseqüência das alterações que ocorrem no conteúdo genético das células tumorais e é regulada por uma variedade de produtos sintetizados a partir de genes específicos. Estes incluem receptores de ligação célula-célula e de ligação célula-matriz extracelular; enzimas proteolíticas que facilitam a degradação e invasão da membrana basal; vasos sangüíneos e/ou 
linfáticos e órgãos; fatores de motilidade que permitem a migração através dos tecidos; receptores que atuam como mediadores da invasão de um órgão específico; fatores de crescimento necessários para a manutenção das microcolônias neoplásicas no órgão secundário e fatores angiogênicos responsáveis pela neovascularização do foco metastático, permitindo o suprimento de nutrientes, remoção de metabólitos e disseminação hematogênica de células metastáticas ${ }^{6,95}$.

Em um epitélio normal, as células epiteliais apresentam-se justapostas, como em paliçadas, ordenadas, estratificadas ou não ${ }^{13}$. As células epiteliais dependem da formação dos contatos de adesão intercelular tanto horizontal quanto verticalmente para formarem camadas contínuas e estratificadas; essa citoarquitetura é responsável pela manutenção da integridade estrutural e funcional dos tecidos ${ }^{13,17,43,79,93,94,101}$. A disfunção da adesão célula-célula é um fator fundamental para que as células neoplásicas malignas produzam metástases. Nos últimos anos, algumas moléculas de adesão celular, bioquímica e geneticamente distintas, foram descritas. Dentre estas, destacam-se as integrinas, a superfamília das imunoglobulinas, as selectinas, as caderinas e o determinante celular CD44,4,6,93. Tem sido sugerido que, possivelmente, todas as moléculas de adesão contribuem, em maior ou menor proporção, com o controle do comportamento das células neoplásicas ou com o direcionamento da resposta imune antitumoral $^{93}$.

Algumas moléculas de adesão apresentam a capacidade de interação homofílica, isto é, duas moléculas iguais interagem entre $\mathrm{si}^{13}$. Entre as moléculas de adesão homofilica, destacam-se as caderinas. As caderinas representam uma família de moléculas de adesão celular transmembranosas, dependentes do cálcio para exercerem suas funções ${ }^{4,13,17,85,94}$. O cálcio é fundamental para a sustentação da estrutura da caderina, se for removido, a porção extracelular da proteína fica flexível e é facilmente digerida pelas enzimas proteolíticas ${ }^{94}$. 
Essas moléculas de adesão são importantes no estabelecimento e manutenção das uniões intercelulares, na determinação da especificidade adesiva das células, ${ }^{85,87,94}$ e no estabelecimento da morfologia tecidual ${ }^{85}$.

A denominação "caderina" foi sugerida inicialmente por Takeichi em 1984, para caracterizar um "sistema de adesão celular dependente do cálcio",86,94,99. São divididas em subclasses de acordo com sua distribuição tecidual e sua nomenclatura deriva-se do tecido no qual estas glicoproteínas foram inicialmente identificadas ${ }^{4,85}$. As caderinas modulam o fenótipo epitelial e a morfogênese de uma variedade de tecidos ${ }^{15}$, sendo expressas em tecidos epiteliais adultos (E-caderina), tecidos nervoso e muscular adultos ( $\mathrm{N}$-caderinas) e placentas e algumas células epiteliais (P-caderinas) ${ }^{3,43,81,95}$. A perda da expressão de E-caderina em tecidos epiteliais é um dos primeiros eventos associados ao processo de transformação celular que ocorrem na progressão tumoral ${ }^{13}$.

A E-caderina geralmente está uniformemente distribuída em todas camadas do epitélio, com exceção da camada mais superficial, enquanto que a P-caderina está concentrada mais intensamente na camada basal ${ }^{3}$. Estas moléculas de adesão não estão aleatoriamente distribuídas sobre as superfícies celulares, mas tendem a localizar-se nas junções especializadas denominadas junções aderentes, onde desempenham um papel fundamental no desenvolvimento destas estruturas ${ }^{81}$.

O gene que codifica a E-caderina humana é o CDH1 situado no braço longo do cromossomo 16. A E-caderina possui um peso molecular de aproximadamente $120 \mathrm{kDa}$ sendo composta por três domínios, um citoplasmático, um transmembranoso e um extracelular, que consiste de cinco subdomínios numerados (C1-C5), onde $\mathrm{C} 1$ representa o mais distante da membrana celular. Este subdomínio C1 contém três aminoácidos dispostos em uma seqüência: histidina, alanina-valina (HAV) sendo essencial para o processo de adesão célula-célula ${ }^{4,6,39,79}$. 
O domínio extracelular da E-caderina se liga, através de ligações homofílicas dependentes do cálcio, ao domínio extracelular de uma molécula de E-caderina de uma célula vizinha, assumindo uma conformação de um "zipper molecular",4,6,39,43,94.

O domínio citoplasmático da E-caderina está ligado fortemente a um grupo de proteínas intracelulares conhecidas como catetinas, que se ligam a actina do citoesqueleto através de interações heterofílicas. Esse complexo formado pelas caderinas, cateninas e actina é denominado de junção aderente, a qual forma um cinto contínuo de adesão intercelular. As cateninas são essenciais para a função das caderinas, pois a "quebra" do complexo E-caderina/ catenina leva à perda da adesão célula-célula mediada pela E-caderina. O complexo Ecaderina/catenina é composto pela $\alpha$-catenina, $\beta$-catenina e $\gamma$-catenina, também conhecida como plakoglobina $4,6,16,39,43,79,93,101$.

Tanto em processos fisiológicos como em patológicos ocorrem alterações na expressão da E-caderina. Dentre os fisiológicos, destaca-se a reação das células epiteliais na cicatrização de feridas. $\mathrm{O}$ fechamento da ferida numa camada epitelial requer não apenas uma redução da adesão celular, mas também uma estimulação da motilidade celular. As alterações apresentadas pelas células epiteliais são induzidas pela liberação de citocinas e outras substâncias ativas após a lesão tecidual. De particular importância é o papel exercido pelo Fator de crescimento epidérmico (EGF) e sua interação com o seu receptor (EGFR). Assim que o defeito tenha se fechado, a adesão celular é desregulada permitindo que o epitélio retome sua resistência inicial ${ }^{6}$.

Acredita-se que mecanismo semelhante ao descrito acima também ocorra na progressão tumoral, através de um mecanismo que envolve as integrinas e as caderinas. Nas ilhotas de carcinomas espinocelulares haveria uma maior expressão das caderinas em detrimento às integrinas, o que restringiria a invasão celular e favoreceria a diferenciação 
celular. Em resposta a estímulos locais poderia ocorrer uma maior expressão de integrinas que poderia levar ao aumento da motilidade e conseqüentemente invasão celular nos tecidos adjacentes, principalmente através da produção de proteases que degradariam a matriz extracelular. Além disso, haveria uma disfunção das caderinas levando a um desequilíbrio na adesão célula-célula. Com o possível estabelecimento destas células neoplásicas em um local secundário haveria aumento da expressão das caderinas e a proliferação celular continuaria $^{38,101}$.

Em um epitélio estratificado normal, a proliferação celular é restrita à camada basal, que está em contato com a membrana basal, e as células movem-se para as camadas suprabasais onde se diferenciam ${ }^{49}$. O crescimento e a proliferação celular são dependentes das interações entre as integrinas e a matriz extracelular; as células que perdem esta ancoragem sofrem apoptose ${ }^{49}$. Assim, que fatores promoveriam o crescimento das células neoplásicas, que possuem intensa proliferação suprabasal e não apresentam contato com a membrana basal, e evitariam a apoptose? KANTAK e KRAMER ${ }^{49}$ verificaram em 1998, em culturas de células neoplásicas, que a adesão celular mediada pela E-caderina poderia agir como um mecanismo compensatório, promovendo a proliferação celular e supressão da apoptose. Os autores acreditam que além dos receptores de fatores de crescimento que estão justapostos aos domínios intercelulares da E-caderina, o processo de compactação celular também seria fundamental para a proliferação celular. O fenômeno da compactação celular é semelhante ao que se observa durante a formação do blastocisto, em que ocorre um alongamento e compressão entre as células adjacentes e requer contração da actina do citoesqueleto, sendo um dos estágios finais para o estabelecimento da adesão celular mediada pela E-caderina ${ }^{49}$.

Células neoplásicas, observadas em cultura, que não expressam E-caderina, apresentam fenótipo mesenquimal, ou seja, com maior capacidade de migração. No entanto, 
estas células passam a apresentar fenótipo epitelial após o restabelecimento funcional do complexo das caderinas, de modo especial à E-caderina ${ }^{17}$. Embora haja evidências de um possível papel de supressão tumoral da E-caderina, ainda não se sabe se esta perda de adesão é pré-requisito para a progressão tumoral ou conseqüência das alterações celulares que ocorrem durante a progressão tumoral in vivo ${ }^{17}$. Geralmente, células com poucas moléculas de caderina apresentam menor adesividade e estão associadas com pior prognóstico em carcinomas de boca $^{15}$.

A expressão imuno-histoquímica de E-caderina em 32 CECs da região de cabeça e pescoço foi avaliada por SCHIPPER et al. $^{76}$ em 1991. Os resultados deste estudo demonstraram que os 15 tumores moderadamente diferenciados expressaram este marcador num padrão heterogêneo e intermediário e que os cinco CECs pouco diferenciados não expressaram E-caderina. Por outro lado, a expressão de E-caderina nos 12 CECs bem diferenciados mostrou-se muito intensa e semelhante ao epitélio normal. Os linfonodos metastáticos foram negativos para a E-caderina. Os autores concluíram que a expressão da Ecaderina exerce um importante papel na progressão dos CECs e que sua diminuição poderia estar associada com a perda da diferenciação e com o aparecimento de metástases.

MATTIJSSEN et al. ${ }^{62}$ avaliaram a expressão imuno-histoquímica de E-caderina em 50 CECs da região de cabeça e pescoço sendo que 27 eram de laringe e 23 de boca. Analisouse a porcentagem de células epiteliais que apresentavam coloração membranosa em cortes por congelação a fresco. Os resultados demonstraram correlação significativa entre o nível de expressão membranosa da E-caderina e o grau de diferenciação, entretanto nenhuma correlação foi observada entre a expressão da E-caderina e os estadiamentos $\mathrm{T}$ e $\mathrm{N}$. Os pacientes que tinham altos níveis de coloração membranosa nos tumores primários 
apresentaram uma melhor sobrevida, sugerindo que a expressão membranosa de E-caderina apresenta importância prognóstica em pacientes com CECs da região de cabeça e pescoço.

A expressão de E-caderina e P-caderina em 25 CECs localizados em gengiva, sendo três em maxila e 22 em mandíbula foi avaliada por SAKAKI et al. ${ }^{73}$. Os tumores foram graduados microscopicamente como bem diferenciados (nove casos), moderadamente diferenciados (12 casos) e pouco diferenciados (quatro casos). Os autores observaram que a expressão reduzida da E-caderina foi significativamente mais elevada em CECs pouco diferenciados de gengiva, sugerindo uma correlação entre a expressão deste marcador e o grau de diferenciação, e que este evento poderia estar relacionado como o padrão de invasão da neoplasia.

A relação entre a expressão imuno-histoquímica de E-caderina e o estadiamento clínico e o grau de diferenciação dos CECs de boca foi avaliada por YAMADA et al. ${ }^{96}$ em 1997. Foram utilizados 18 CECs primários, sendo três bem, 11 moderadamente e quatro pouco diferenciados, dois linfonodos metastáticos e seis fragmentos de mucosa bucal normal como controle. Notou-se que nos linfonodos metastáticos, as células localizadas mais no centro das ilhotas tumorais apresentavam uma maior expressão de E-caderina quando comparadas às células dos tumores primários o que sugeriria que a perda de expressão da E-caderina durante a progressão tumoral é um evento dinâmico e reversível. Observou-se ainda que a redução da expressão deste marcador foi mais proeminente nas células periféricas das ilhotas tumorais localizadas na região do front de invasão tumoral. Os autores concluíram que a perda da expressão de E-caderina correlacionou-se significativamente com os estadiamentos $\mathrm{T}$ e $\mathrm{N}$ mais avançados e com a perda da diferenciação dos CECs de boca por eles estudados.

SHINOHARA et al. ${ }^{77}$ estudaram, dentre outros marcadores imuno-histoquímicos, a intensidade da imunomarcação da E-caderina em 54 CECs primários de boca. Destes, apenas 
28 apresentavam comprometimento linfonodal. A maioria dos tumores estava localizada em língua (dez casos), gengiva (seis em mandíbula e dois em maxila), soalho bucal (cinco casos), mucosa jugal (três casos) e somente dois tumores estavam localizados no palato. Os autores concluíram que a redução da expressão de E-caderina correlacionou-se com o comportamento invasivo e metastático de todos os carcinomas espinocelulares. Entretanto, não houve uma correlação entre a perda da expressão da E-caderina e o grau de diferenciação celular.

As alterações moleculares que levam à perda de expressão da E-caderina têm sido amplamente estudadas. YOKOYAMA et al. ${ }^{98}$, em 2001, analisaram em linhagens celulares de carcinomas espinocelulares de boca, a correlação entre do fator de repressão transcricional snail e a molécula da E-caderina. O fator snail tem sido implicado na diferenciação das células epiteliais para um fenótipo mesenquimal, devido a sua ligação aos elementos E-box da região promotora do gene $C D H 1$ que provocaria a repressão da transcrição deste gene.

Os ensaios imuno-histoquímicos foram realizados em duas linhagens celulares, uma que expressava fortemente a E-caderina (HOC313 e ZA) e outras que não expressavam (HOC313 e TSU); ambas linhagens expressaram níveis similares de mRNAs para $\alpha$ e $\beta$ catenina. Os resultados demonstraram uma forte expressão do repressor transcricional snail nas linhagens que não expressaram E-caderina, nas que expressavam esta molécula de adesão este fator não foi observado. Segundo os autores, a expressão do repressor snail pode ter um importante papel no processo invasivo e desenvolvimento de metástases durante a progressão das neoplasias bucais. No entanto, outros estudos quanto ao comportamento biológico dos tumores bucais malignos devem ser realizados, pois além do fator de repressão snail outras alterações podem afetar a transcrição do gene $C D H 1$ como os fatores de repressão SIP-1 e $\delta E F 1 / Z E B 1$ e a hipermetilação das ilhas de $\mathrm{CpG}^{19,98}$. 
Correlação entre os parâmetros clínicos e marcadores imuno-histoquímicos como a E-caderina em relação à ocorrência de metástases linfonodais ocultas foi avaliada por OKAMOTO et al. ${ }^{67}$ em 2002. Foram analisados 59 carcinomas espinocelulares de língua, com estadio I e II, dos quais 35 eram bem, 19 moderadamente e cinco pouco diferenciados. Metástase linfonodal oculta foi verificada em $27(18,5 \%)$ e $32(28,1 \%)$ pacientes com estadio I e II respectivamente. Estas metástases foram diagnosticadas clinicamente num período de cinco anos, sendo a grande maioria $(78,6 \%)$ em dois anos. Expressão normal da E-caderina foi observada em $43,9 \%$ dos espécimes, enquanto $56,1 \%$ apresentaram perda de expressão. Não houve correlação entre a expressão desta molécula e a ocorrência de metástases ocultas, que poderia ser reflexo, segundo os autores, do pequeno tamanho dos tumores, principalmente, os pouco diferenciados.

Outros estudos avaliaram conjuntamente a expressão dos marcadores E-caderina e de uma das cateninas, proteínas que formam o complexo E-caderina/catenina e são fundamentais para a manutenção da adesão intercelular normal ${ }^{16,19,39,81,86,95}$. De modo geral, a imunomarcação da E-caderina e das cateninas é mais intensa nos tumores bem diferenciados, que mantêm sua adesividade celular e são menos invasivos, mas é reduzida em tumores pouco diferenciados que perderam a adesão célula-célula e mostram um comportamento biológico mais agressivo, com aumento do potencial invasivo e desenvolvimento de metástases, associado a uma piora do prognóstico dos pacientes ${ }^{6,81,86,95}$.

Quanto ao carcinoma verrucoso, dois estudos foram publicados recentemente na literatura chinesa.

TIAN; GUO; ZHANG ${ }^{88}$, em 2002, além de avaliarem o potencial de invasão e metástase dos carcinomas verrucosos, basocelulares e espinocelulares de boca, verificaram a possibilidade da E-caderina atuar como fator de prognóstico. Foram analisados 60 espécimes 
de carcinoma espinocelular e 30 de carcinoma basocelular, dos quais $38,2 \%$ e $0,04 \%$, respectivamente, tiveram recorrência e/ou metástase após o tratamento cirúrgico. Nenhum dos 30 espécimes de carcinoma verrucoso analisados apresentou recorrência. Quanto à expressão da E-caderina, diferença estatisticamente significante foi observada entre o carcinoma espinocelular e os demais carcinomas, verrucoso $(p<0,01)$ e basocelular $(p<0,05)$. Segundo os autores, houve uma correlação entre a perda da expressão da E-caderina e ao maior potencial de invasão e metástase na amostra analisada, o que sugere um importante papel da E-caderina como fator de prognóstico.

A expressão imuno-histoquímica da E-caderina em 12 carcinomas verrucosos e 20 carcinomas espinocelulares, todos de boca, foi avaliada por TANG; ZOU; XIE ${ }^{87}$, em 2003. Observaram que a expressão positiva desta molécula de adesão foi estatisticamente significativa $(p<0,05)$ entre o carcinoma verrucoso $(83,3 \%)$ e o carcinoma espinocelular pouco diferenciado (37,5\%). A expressão negativa da E-caderina nos carcinomas verrucosos situouse, percentualmente, entre o carcinoma espinocelular bem e pouco diferenciado. Segundo os autores a expressão positiva da E-caderina nos carcinomas verrucosos pode representar um importante papel no comportamento deste tumor.

\subsection{Hipermetilação da região promotora do gene da E-caderina em carcinomas espinocelulares}

A carcinogênese constitui-se um processo de múltiplos passos, caracterizado pela ocorrência ou acúmulo de alterações genéticas como: mutações pontuais (substituições, deleções e inserções), cromossômicas (duplicações, translocações, inserções e deleções) e alterações epigenéticas $^{26,27,28,29}$. 
Alterações epigenéticas são aquelas que modificam a constituição química do DNA e não alteram diretamente a seqüência de nucleotídeos ${ }^{23,26,27,78,92}$. A principal modificação epigenética nos mamíferos e em particular nos humanos é a metilação, que consiste em um fenômeno biológico caracterizado pela adição de um radical metil $\left(\mathrm{CH}_{3}\right)$ principalmente nas bases nitrogenadas citosinas $(C)$ localizadas a montante de guaninas $(\mathrm{G})$, que geralmente são expressas como $\mathrm{CpG}^{23,26,27,78,92}$. A expressão $\mathrm{CpG}$ representa a união das bases nitrogenadas citosina e guanina por uma ligação fosfodiéster na mesma fita de DNA, contrastando dos pares de base CG unidos por pontes de hidrogênio e localizados em fitas opostas na dupla hélice do DNA $^{23,26,27,78,92}$.

A metilação das citosinas nos dinucleotídeos $\mathrm{CpG}$ é uma característica comum dos genomas eucarióticos ${ }^{23}$. Mutações nas enzimas responsáveis pelo estabelecimento e manutenção do perfil de metilação genômico resultam na morte embrionária precoce de camundongos ${ }^{23}$.

Em células eucarióticas normais as regiões metiladas sofreram uma redução significativa com o processo evolutivo e teriam um provável papel em estabelecer regiões transcricionalmente inativas e na defesa do DNA ao reprimir a transcrição de seqüências de DNA exógenas, como os elementos retrovirais ${ }^{5,23}$.

Seqüências repetitivas do dinucleotídeo CG presentes principalmente em regiões promotoras dos genes recebem a denominação de ilhas de $\mathrm{CpG}$. O conceito mais aceito para ilha de CpG é que ela seja maior que 200 pares de base, mostrando uma quantidade de citosina somado ao de guanina maior que $50 \%$ e que a proporção entre CG e GC seja maior que $60 \%{ }^{89}$. Estima-se que existam no genoma humano em torno de 45 mil ilhas de $\mathrm{CpG}$, que estão localizadas nas regiões promotoras e nos primeiros éxons de aproximadamente $60 \%$ dos genes $^{23}$. CpGs dentro das ilhas de $\mathrm{CpG}$ são normalmente não metiladas enquanto que a 
maioria das CpGs fora das ilhas são metiladas. Outras seqüências como 5'-CpA-3'ou 5'CpT3' também podem exibir metilação mas, em uma freqüência baixa ${ }^{23}$. As ilhas de CpG, da região promotora do gene, encontram-se metiladas nas células eucarióticas apenas em alelos de genes autossômicos silenciados por imprinting ou no cromossomo X feminino inativado ${ }^{5}$. Acredita-se que este modelo de distribuição de metilação é responsável pela compartimentalização do genoma em áreas transcricionalmente ativas e inativas ${ }^{23}$.

O processo de metilação é mediado pelas DNA metiltransferases (DNMTs), que são as enzimas que transferem o radical metil para a citosina e são subdivididas em DNMT1, DNMT2, DNMT3a e DNMT3b, sendo o alvo desta enzima o dinucleotídeo $\mathrm{CG}^{35}$. A DNMT1 possui alta afinidade por substratos hemimetilados, e apresenta também a capacidade de atuar na metilação de substratos não metilados, ou seja, metilação de novo. A replicação de uma seqüência metilada leva a uma seqüência hemimetilada, pois uma fita permanece metilada enquanto a fita recém-sintetizada está desmetilada. Desse modo, as enzimas DNMTs adicionam um radical metil ao dinucleotídeo complementar da fita mãe. Além do estabelecimento, as DNMTs promovem também a manutenção dos padrões de metilação. As conseqüências da metilação de citosinas nas regiões promotoras sugerem que este mecanismo inibe a transcrição gênica impedindo seu início ${ }^{23,26,27,78,92}$.

Dois mecanismos já foram propostos para a inativação da transcrição que ocorre em regiões metiladas do DNA:

- Interferência direta na ligação de fatores de transcrição aos seus locais de reconhecimento na região promotora do gene, ou seja, há perda da afinidade de ligação dos fatores de transcrição às suas seqüências alvo, devido à presença do radical metil. $\mathrm{O}$ grupamento metil não afeta $\mathrm{o}$ pareamento de bases, mas podem influenciar em interações DNA- 
proteínas por se projetarem no sulco maior da dupla fita da molécula de $\mathrm{DNA}^{47}$;

- Ligação de repressores transcricionais específicos ao DNA metilado (methyl cytosine binding proteins 1 and 2 ou MeCP1 e MeCP2 e methyl binding proteins ou MBPs), que além de competirem com os fatores de transcrição poderiam atrair complexos protéicos como as histonas deacetilases (HDACs), que são enzimas responsáveis pela remoção de um grupo acetil das histonas promovendo assim, uma compactação da cromatina. Essa condensação da cromatina faz com que o DNA fique menos acessível aos fatores de transcrição ${ }^{23,92}$.

No entanto, acredita-se que haja uma cooperação desses mecanismos no silenciamento da transcrição de determinados genes, ou seja, haveria uma associação entre a atividade da maquinaria de metilação considerando a ação das proteínas das famílias das DNMTs, MeCPs e MDBs, com outro mecanismo epigenético, a acetilação de histonas, levando-se em consideração a ação das $\mathrm{HDACs}^{23,78}$.

Nas neoplasias malignas a metilação tem sido verificada em locais não metilados em células normais impedindo a transcrição gênica, como em regiões promotoras de genes supressores tumorais envolvidos no sistema de reparo DNA, nos mecanismos regulatórios da apoptose e também nas propriedades de adesão celular. ${ }^{23,26,27,78,92}$. Esse padrão de metilação também poderia afetar indiretamente a atividade gênica através de transtornos no processo transcrição-tradução devido ao aumento da possibilidade de mutações pontuais resultando em instabilidade cromossômica. Isso ocorreria porque na citosina metilada há uma grande possibilidade de ocorrer uma deaminação espontânea o que resultaria na formação da base nitrogenada timina ${ }^{92}$. Essas alterações no padrão de metilação possivelmente precederiam e 
seriam essenciais para a ocorrência das alterações genéticas responsáveis pela progressão tumoral $^{5}$. Já nas células normais o padrão de metilação do DNA conserva-se ao longo dos ciclos de divisão celular, permitindo a expressão de um conjunto particular de genes necessários à atividade normal da célula ${ }^{26,27}$.

A ocorrência de metilação em sítios previamente não metilados, como na região promotora de um gene supressor de tumor que poderia resultar na sua inativação pela inibição da transcrição e conseqüente incapacidade de impedir a proliferação celular, também tem sido denominada de hipermetilação ${ }^{92}$.

As alterações genéticas em genes supressores de tumor geralmente estão associadas a uma perda de função, dessa forma, essas alterações são recessivas em relação à manifestação do fenótipo maligno, havendo necessidade de inativação dos dois alelos. $\mathrm{KNUDSON}^{53}$, em 1971, avaliando casos esporádicos e familiares de retinoblastoma, propôs a hipótese do two hits para a inativação de genes supressores de tumor. De acordo com essa hipótese, duas alterações genéticas (hits) distintas, envolvendo os dois alelos, seriam necessárias para que houvesse a inativação de um gene supressor de tumor. Nos casos esporádicos de câncer, as duas alterações ocorreriam no tecido afetado ao longo da vida do indivíduo e seriam, portanto, mutações somáticas. Já nos casos familiares de câncer, uma das alterações seria herdada dos pais (mutação germinativa) e a segunda ocorreria através de uma mutação somática no tecido afetado. Assim, o fato de a metilação de ilhas de $\mathrm{CpG}$ localizadas em promotores gênicos poder causar silenciamento da transcrição, somada à observação de padrões alterados de metilação em células cancerosas, poderia sugerir que esta seria uma via em potencial a ser acrescentada na hipótese de Knudson para inativação de genes supressores de tumor ${ }^{47}$. 
Além da hipermetilação observada nos tumores malignos, tem-se observado que o padrão de metilação tenderia a aumentar com o envelhecimento o que poderia elevar a predisposição individual ao câncer ${ }^{89}$.

Quanto às propriedades de adesão celular, alguns estudos avaliaram o padrão de metilação da região promotora do gene $C D H 1$, que codifica a molécula da E-caderina, em carcinomas espinocelulares de cabeça e pescoço ${ }^{14,15,41,57,64,91,97}$.

A causa da perda ou diminuição da expressão da E-caderina em carcinomas espinocelulares de boca ainda não é conhecida, sendo que diferentes alterações moleculares já foram relatadas como deleções, mutações do gene CDH1 e mais recentemente a hipermetilação da região promotora deste gene $\mathrm{e}^{14,15,17,19,41,57,64,91,97,98}$.

O valor prognóstico da perda de expressão de E-caderina foi avaliado por CHANG et al. ${ }^{14}$, em carcinomas espinocelulares de língua. A freqüência de hipermetilação da região promotora do gene da E-caderina em pacientes que apresentaram recidiva tumoral foi de $71 \%$ e nos que desenvolveram metástases linfonodais esta freqüência foi de $67 \%$. Também foi verificada uma forte associação entre a hipermetilação do promotor gênico da E-caderina e a ausência de expressão de sua proteína correspondente. Os autores verificaram que a hipermetilação do gene da E-caderina apresentou significativo valor prognóstico sendo considerada juntamente com os demais parâmetros ( $\mathrm{T}$ e $\mathrm{N}$ ) como fator de prognóstico independente para a sobrevida livre de doença.

NAKAYAMA et al. ${ }^{64}$, em 2001, avaliaram a correlação entre a expressão imunohistoquímica da E-caderina e a hipermetilação da região promotora do gene CDH1. Dos 23 carcinomas espinocelulares de boca analisados, cinco apresentaram uma expressão forte de Ecaderina e destes, apenas uma amostra apresentava-se metilada. No entanto, dos 18 carcinomas em que observaram uma redução da expressão da E-caderina, 17 estavam 
metilados. Os autores verificaram também o perfil de metilação de duas linhagens celulares de carcinoma espinocelular de língua, previamente estudadas quanto à expressão da E-caderina:

- UM1: fraca expressão de E-caderina, com alto potencial invasivo metastático;

- UM2: forte expressão de E-caderina, com baixo potencial invasivo e metastático.

Observaram que apenas UM1 apresentava-se metilada e que a mesma restabeleceu significativamente a expressão de E-caderina após o tratamento com um agente desmetilante (5-azacitidina). Segundo os autores, os resultados demonstraram haver uma correlação entre a redução da expressão de E-caderina e a metilação da região promotora do gene $C D H 1$.

Correlação entre a hipermetilação do gene $C D H 1$ e a expressão imuno-histoquímica da proteína E-caderina em carcinomas espinocelulares de boca, também foi verificada por YEH et al. ${ }^{97}$ em 2002. Foram analisados 48 carcinomas espinocelulares de boca e 48 margens tumorais livres da lesão correspondentes aos mesmos tumores. Os resultados mostraram que $41(85,4 \%)$ tumores e $16(33,3 \%)$ margens apresentavam hipermetilação do gene da Ecaderina. Quanto à imuno-histoquímica, verificaram que a proteína estava expressa na membrana, citoplasma e núcleo celular e que se distribuía de maneira homogênea ou heterogênea. A expressão citoplasmática e nuclear distribuída heterogeneamente predominou nos tecidos tumorais com hipermetilação do gene da E-caderina quando comparados às margens, onde se observou principalmente marcação membranosa. Já os tumores não metilados apresentaram, principalmente, marcação membranosa e homogênea Segundo os autores a ocorrência da hipermetilação na região promotora do gene da E-caderina é provavelmente um evento precoce no desenvolvimento do câncer bucal devido à detecção 
deste processo nas margens tumorais. E que tanto o evento da hipermetilação quanto a expressão da E-caderina são dinâmicos, podendo sofrer alterações de acordo com o microambiente celular, conferindo à célula capacidade de sobreviver em diferentes meios.

VISWANATHAN; TSUCHIDA; SHANMUGAM ${ }^{91}$, em 2003, dentre outros genes analisados, verificaram a ocorrência de hipermetilação do gene da E-caderina em, aproximadamente, $35 \%$ do total de 99 carcinomas espinocelulares de boca analisados. Avaliaram também 25 amostras livres de comprometimento tumoral e nenhuma destas apresentou metilação do gene $C D H 1$. Concluem os autores, que os mecanismos epigenéticos podem ser fundamentais no desenvolvimento dos carcinomas bucais, podendo, em alguns casos, substituir os eventos genéticos na inativação dos genes responsáveis pela progressão tumoral.

Outro aspecto relevante seria que a perda da expressão da E-caderina, principalmente por hipermetilação, modulasse a expressão dos outros subtipos de caderinas, de modo especial à $\mathrm{N}$-caderina. Essa inter-relação entre as caderinas é relevante para o conceito da transição epitélio-mesênquima (EMT) que ocorre nos tumores malignos. Verificou-se que a perda da expressão da E-caderina leva a um aumento de expressão de N-caderina, que estaria relacionada com um aumento da mobilidade e migração celular, ou seja, aquisição de um fenótipo maligno ${ }^{15}$. CHEN et al. ${ }^{15}, 2004$, avaliaram o nível de expressão de E-caderina e Ncaderina em 14 linhagens celulares de carcinomas espinocelulares de boca. Observaram que 12 linhagens expressaram E-caderina em diferentes níveis e $4 \mathrm{~N}$-caderina. No entanto, as duas linhagens (HOC-313 e HA-376) que não expressaram E-caderina estavam superexpressas para N-caderina e quando verificadas por imunofluorescência apresentavam morfologia fibroblástica, o que estaria relacionada com uma maior capacidade de migração e mobilidade 
celular. Quando realizaram a MSP para verificar o padrão de metilação do gene da E-caderina, observaram que apenas estas duas linhagens apresentaram-se hipermetiladas, sendo que HA376 apresentou tanto a banda metilada como a não metilada e HCO-313 apresentou apenas a banda metilada. Após o tratamento destas linhagens com uma substância desmetilante (5-AzaCdR), a linhagem HA-376 voltou a expressar E-caderina, reduziu a expressão da N-caderina significativamente e apresentou por imunofluorescência morfologia epitelial. Na linhagem HCO-313, a substância desmetilante não foi capaz de reverter a hipermetilação da região promotora do gene, assim, as células continuaram a expressar fortemente a N-caderina. Segundo os autores, na linhagem HCO-313 além da hipermetilação da região promotora do gene poderia haver alguma mutação pontual ou deleção parcial o que poderia explicar o motivo que estas células não expressaram E-caderina após o tratamento com a substância desmetilante e continuaram a expressar fortemente $\mathrm{N}$-caderina.

Como alguns trabalhos já demonstraram, a perda da expressão imuno-histoquímica da E-caderina pode ser dinâmica, instável e reversível durante o processo metastático e estaria associada com a expressão de outras proteínas como as integrinas ${ }^{38,101}$. Em alguns tumores, como tumores ginecológicos, gástricos e o carcinoma lobular de mama, já foi observado que essa perda de expressão seria decorrente de mutação no gene $C D H 1$, que resulta numa perda de expressão irreversível ${ }^{38,101}$. No entanto, acredita-se que em muitos tumores a perda de expressão de E-caderina ocorra por alterações reversíveis, principalmente por hipermetilação ${ }^{38,57,101}$. As células tumorais num determinado momento apresentariam hipermetilação da região promotora do gene $C D H 1$, o que levaria à interrupção do processo de transcrição e conseqüente falha na produção da proteína E-caderina. Iriam adquirir assim, mobilidade e capacidade de invasão. A partir do momento que estas células metastáticas atingissem um tecido secundário passariam a expressar a proteína E-caderina novamente, 
restabelecendo as junções intercelulares, o que seria fundamental para a sobrevivência celular $^{38,101}$ (Figura 1). Essas alterações ocorreriam de maneira randômica, ou seja, nas neoplasias existiriam uma variedade de subpopulações celulares com diferentes potenciais metastáticos ${ }^{57}$.

Os mecanismos responsáveis pela indução da metilação da região promotora do gene $C D H 1$ permanecem obscuros. HASEGAWA et al. ${ }^{41}$ avaliaram o perfil de hipermetilação do gene da E-caderina em 80 carcinomas espinocelulares de cabeça e pescoço, dos quais, 29 $(36,3 \%)$ encontravam-se metilados. Estes autores observaram uma correlação estatisticamente significante entre os espécimes metilados e a exposição ao tabaco, tanto para o período de tempo que o vício de fumar existia quanto para a quantidade de cigarros fumados anualmente $(p<0,03)$. Em relação ao consumo de álcool, houve uma correlação estatisticamente marginal quanto aos anos em que este vício existia $(\mathrm{p}<0,07)$. Segundo os autores, o tabaco pode ter um papel importante para a ocorrência da metilação, mas outros estudos são necessários para verificarem estes dados.

Quanto à hipermetilação do gene da E-caderina em carcinomas verrucosos de boca, nenhum trabalho foi verificado na literatura científica. Entretanto, sendo esta neoplasia caracterizada por sua baixa agressividade, bom prognóstico e geralmente ausência de metástases, o estudo da hipermetilação da região promotora do gene $C D H 1$, como proposto neste trabalho, poderá contribuir com o conhecimento mais abrangente do comportamento biológico desta lesão, principalmente quanto a sua progressão. 


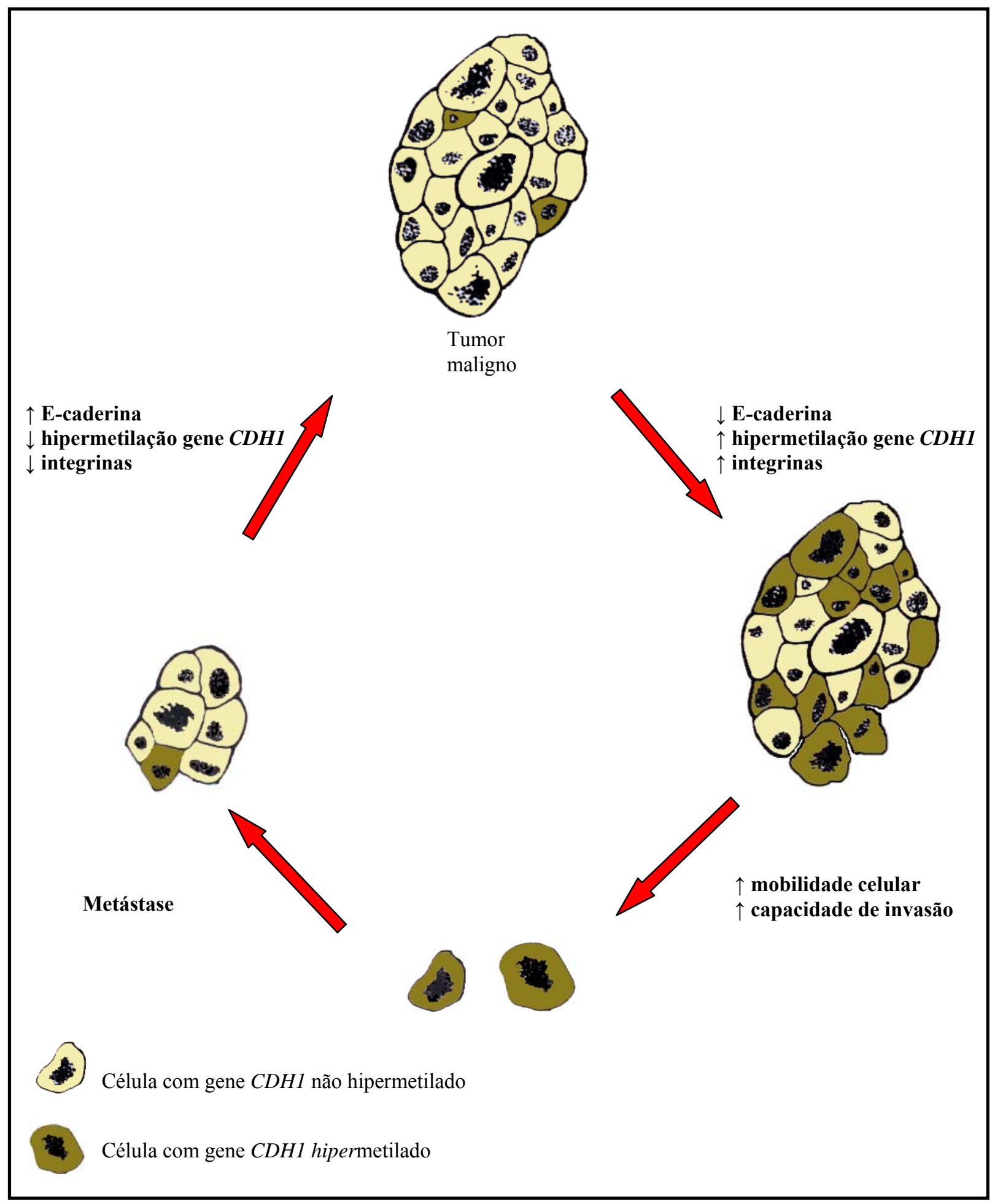

FIGURA 1 - Representação esquemática das alterações moleculares da E-caderina durante a progressão tumoral. Adaptada de ZIOBER et al. ${ }^{101}$, 2001 
3 PROPOSIÇÃO 


\section{PROPOSIÇÃO}

Os principais objetivos deste estudo foram:

3.1 Avaliar, retrospectivamente, os carcinomas verrucosos de boca diagnosticados e tratados no Hospital A.C. Camargo, em São Paulo, no período de 1980 a 2000, quanto:

a) aos dados demográficos e características clínicas da lesão;

b) aos aspectos microscópicos e as formas de tratamento;

c) evolução clínica das lesões e taxas de sobrevida dos pacientes portadores desta neoplasia.

3.2 Comparar o padrão de hipermetilação do gene da E-caderina e a expressão imuno-histoquímica desta molécula de adesão em carcinomas verrucosos e espinocelulares bem diferenciados localizados exclusivamente na boca.

3.3 Avaliar a influência da hipermetilação e da expressão imunohistoquímica da E-caderina no prognóstico dos pacientes com carcinoma verrucoso e espinocelular bem diferenciados. 
4 MATERIAL E MÉTODOS 


\section{MATERIAL E MÉTODOS}

\subsection{População de estudo e seleção da amostra}

A população de estudo foi constituída por pacientes submetidos ao tratamento de carcinoma verrucoso de boca no Departamento de Cirurgia de Cabeça e Pescoço e Otorrinolaringologia do Centro de Tratamento e Pesquisa do Hospital do Câncer A.C. Camargo, em São Paulo, no período de 1980 a 2000. Foram analisados todos os prontuários de pacientes com diagnóstico inicial de carcinoma verrucoso e de carcinoma espinocelular bem diferenciado. Os seguintes critérios de inclusão descritos por KOWALSKI et al. ${ }^{55}$ foram utilizados:

1) pacientes com tumor primário com o diagnóstico de carcinoma verrucoso e/ou carcinoma espinocelular bem diferenciado confirmado por biópsia e localizado em qualquer região da boca (lábio, língua, mucosa jugal, assoalho, palato, gengivas e área retromolar);

2) pacientes que não tenham se submetido a tratamento prévio;

3) pacientes submetidos à cirurgia ou radioterapia como tratamento inicial com finalidade curativa;

4) seguimento clínico completo;

5) disponibilidade dos blocos de parafina dos referidos tumores, bem como a adequada conservação dos espécimes;

6) disponibilidade de fragmentos representativos das neoplasias. 
Os critérios de exclusão foram:

1) contra-indicação para cirurgia (pacientes considerados inoperáveis);

2) presença de metástase a distância no momento da admissão no hospital;

3) presença de outros tumores primários simultâneos;

4) pacientes submetidos à quimioterapia como tratamento;

5) pacientes que recusaram o tratamento;

6) pacientes tratados com finalidade paliativa.

Para a análise da expressão imuno-histoquímica da E-caderina e do perfil de metilação do gene da E-caderina, procurou-se parear, pela localização, os carcinomas verrucosos de boca selecionados com carcinomas espinocelulares bem diferenciados, que representaram dois grupos de acordo com a ocorrência ou não de comprometimento linfonodal, confirmado microscopicamente. A fim de detectar o padrão de metilação do gene da E-caderina, em uma amostra não maligna, espécimes de hiperplasias fibrosas (HFs) de boca foram selecionadas. A amostra tumoral constitui-se:

- CV: Carcinoma verrucoso de boca;

- CEC-pN0: Carcinoma espinocelular bem diferenciado de boca sem comprometimento linfonodal, confirmado microscopicamente;

- CEC-pN+: Carcinoma espinocelular bem diferenciado de boca com comprometimento linfonodal, confirmado microscopicamente.

\subsection{Registro dos dados clínico e microscópico}

As informações referentes aos pacientes foram registradas em formulário próprio, adaptado de KOWALSKI et al. ${ }^{55}$ e obtidas a partir do banco de dados pertencente ao Serviço de Arquivo Médico (SAME) do Hospital do Câncer A.C. Camargo. Estes registros incluíram a 
identificação e os dados demográficos dos pacientes, informações relativas à história clínica, ao exame locorregional, cirurgia, radioterapia pós-operatória, microscopia da peça cirúrgica inicial e evolução do paciente como observado no formulário proposto para a coleta de dados (Anexo).

Realizou-se a análise morfológica qualitativa dos espécimes selecionados em cortes microscópicos de $3 \mu \mathrm{m}$ de espessura obtidos a partir das peças cirúrgicas incluídas em parafina dos carcinomas verrucosos e carcinomas espinocelulares bem diferenciados, arquivados no Laboratório de Anatomia Patológica do Hospital do Câncer A.C. Camargo. Estes cortes foram corados pela técnica da Hematoxilina e Eosina (HE) seguindo-se os procedimentos histotécnicos de rotina do Laboratório de Anatomia Patológica do referido hospital.

A análise morfológica dos tumores primários foi realizada individualmente por três examinadores (RVM, GL, DTO) utilizando-se de um microscópio óptico binocular ZEISS, modelo Axioskop2-plus, sendo os pontos de discordância entre estes reavaliados e estabelecidos por um consenso. Utilizou-se um corte representativo do tumor primário de cada caso, analisando-se todo o fragmento neoplásico presente na lâmina, para a determinação das características microscópicas relativas ao padrão de configuração e morfologia tumoral.

\subsection{Variáveis de estudo}

As variáveis analisadas neste estudo referem-se aos dados demográficos relativos aos pacientes como o gênero (masculino ou feminino), a idade e a raça (branca, ou não branca).

Quanto à história clínica dos pacientes, pesquisou-se o tempo de história (meses), tabagismo e etilismo. Analisaram-se também as queixas dos pacientes, se referentes ao tumor primário, às metástases regionais ou a ambos. No exame locorregional, a localização do tumor 
primário foi registrada como: 1- lábio superior; 2- lábio inferior; 3- língua; 4- assoalho bucal; 5- gengiva superior; 6- palato duro; 7- palato mole; 8- gengiva inferior; 9- mucosa jugal e 10área retromolar.

Quanto às características clínicas, as lesões foram descritas como ulcerovegetantes ou ulceroinfiltrativas.

Registraram-se as classificações clínicas TNM/UICC, T (T1, T2, T3, T4 e Tx) e N (N0, N1, N2a, N2b, N2c e N3), agrupando-as para análise em T1-2 e T3-4, N0 e N+.

Quanto ao tratamento, registraram-se a data da cirurgia, a realização ou não de esvaziamento cervical, o tipo de esvaziamento cervical (ipsilateral ou ipsilateral e contralateral simultâneos), a data da alta hospitalar e a realização ou não de radioterapia e quimioterapia pós-operatórias.

A análise microscópica inicial da peça cirúrgica baseou-se primeiramente no diagnóstico do tumor primário referente ao laudo anatomopatológico.

As características tumorais como hipercromatismo e o pleomorfismo celulares, a queratinização, as mitoses atípicas, a acantose e o infiltrado inflamatório (mononuclear e polimorfonuclear), foram classificados como ausentes, discretos, moderados ou intensos, utilizando-se de parâmetros comparativos entre os diferentes tumores analisados. O padrão de invasão tumoral também foi analisado bem como a integridade da membrana basal.

A embolização vascular angiolinfática e a infiltração tumoral muscular, óssea, perineural e de glândulas salivares foram classificadas como ausentes ou presentes.

A evolução dos pacientes foi avaliada pela ocorrência ou não de recidiva local, cervical, de metástase a distância e de segundo tumor primário.

Com o objetivo de caracterização da amostra, registraram-se também a data da primeira recidiva, os locais da recidiva (0- não teve; 1 - local; 2- pescoço ipsilateral; 3 - pescoço 
contralateral; 4- pulmão; 5- osso; 6- fígado; 7- outra a distância; 8- recidiva em local ignorado e 9- ignorado), a data do diagnóstico do segundo tumor primário e o local do segundo tumor primário.

Foram registradas a data da última informação de seguimento e a situação do paciente: 1- vivo sem evidência da doença $(000)$; 2- vivo com câncer; 3- morte por intercorrência cirúrgica (MOCI); 4- morte decorrente do câncer (MOCA); 5- morte por outras causas não relacionadas ao câncer (MOASS) e 6- perdido de vista. Pacientes perdidos de vista eram considerados aqueles com menos de cinco anos de seguimento. Pacientes assintomáticos perdidos de vista após cinco anos foram classificados como vivos livres da doença. Os prontuários dos pacientes perdidos de vista foram encaminhados aos responsáveis pela convocação destes pacientes e as respostas obtidas foram posteriormente conferidas.

\subsection{Análise da hipermetilação do gene da E-caderina nos carcinomas bucais}

\subsubsection{Extração de DNA}

Todos os procedimentos laboratoriais para a detecção do padrão de metilação do gene da E-caderina foram realizados no Laboratório de Genética do Câncer (LGNC) do Instituto Ludwig de Pesquisa sobre o Câncer, em São Paulo. Em apenas um espécime, do grupo $\mathrm{CV}$, não foi encontrado o bloco parafinado do respectivo tumor. Os espécimes de carcinoma verrucoso e carcinomas espinocelulares bem diferenciados de boca, incluídos em parafina, foram corados pela técnica da Hematoxilina e Eosina e analisados microscopicamente para a determinação das áreas tumorais mais representativas, visando à extração de DNA da maior proporção tumoral. Posteriormente, foram confeccionados novos cortes microscópicos onde as áreas tumorais selecionadas eram determinadas por similaridade ao corte de HE sendo o tecido tumoral removido da lâmina de vidro por dissecção manual, 
com auxílio de uma lâmina de bisturi. Para padronização e controle da reação de PCR foram utilizadas três linhagens celulares, que eram provenientes da ATCC - American Type Culture Collection. Para o controle do estado metilado utilizou-se da linhagem H 1299 (derivada do carcinoma de células não pequenas de pulmão) e HCT 116 (derivada de carcinoma colorretal) e para o controle do estado não metilado, a linhagem MCF-7 (derivada de adenocarcinoma de mama). Extraiu-se também o DNA de cinco hiperplasias fibrosas (HFs), a fim de detectar o perfil de metilação do gene $C D H 1$ em tecido não neoplásico. Os tecidos tumorais e os não neoplásicos incluídos em parafina foram submetidos à extração de DNA utilizando-se o kit Nucleon HT (Amersham Biosciences), conforme protocolo estabelecido pelo fabricante, com adaptações:

1) Primeira etapa - desparafinização:

a) dissecar as áreas selecionadas nos cortes de parafina e colocar o material obtido em tubos de microcentrífuga $1,5 \mathrm{~mL}$;

b) adicionar $1 \mathrm{~mL}$ de xilol e homogeneizar;

c) incubar os tubos a $37^{\circ} \mathrm{C}$ por vinte minutos;

d) centrifugar por cinco minutos a 13.200rpm;

e) retirar o sobrenadante com cuidado e descartar;

f) adicionar ao precipitado $1 \mathrm{~mL}$ de etanol com concentrações decrescentes (100, 75, 50 e $25 \%)$;

g) após cada troca de etanol, homogeneizar e centrifugar por três minutos a $13.200 \mathrm{rpm}$

h) adicionar $1 \mathrm{~mL}$ de água destilada livre de DNAse e RNAse (GIBCO BRL®);

i) centrifugar por três minutos a 13.200rpm; 
j) retira-se o sobrenadante com cuidado.

2) Segunda fase - digestão do tecido:

a) adicionar $350 \mu \mathrm{L}$ do Reagente B (kit Nucleon $H T{ }^{\circledR}$, Amersham Biosciences);

b) nos tubos, que já contêm o Reagente $\mathrm{B}$, adiciona-se $20 \mu \mathrm{L}$ $(200 \mu \mathrm{g} / \mathrm{mL})$ de Proteinase K (kit Nucleon HT®, Amersham Biosciences);

c) incubar, overnight, a $55^{\circ} \mathrm{C}$.

3) Terceira fase - desproteinização:

a) adicionar $100 \mu \mathrm{L}$ de Perclorato de sódio (kit Nucleon HT®, Amersham Biosciences) nos tubos, que já continham o Reagente B e a Proteinase K.

4) Quarta fase - extração e precipitação do DNA:

a) aos mesmos tubos da etapa anterior, adicionar $600 \mu \mathrm{L}$ de clorofórmio e homogeneizar;

b) adicionar $150 \mu \mathrm{L}$ da Resina (kit Nucleon HT®, Amersham Biosciences) e não homogeneizar;

c) centrifugar por um minuto a 2000rpm;

d) remover o sobrenadante e colocá-lo em novo tubo de microcentrífuga de $1,5 \mathrm{~mL}$;

e) centrifugar por um minuto a 2000rpm, para verificar possíveis resíduos da Resina e clorofórmio;

f) adicionar $1 \mathrm{~mL}$ de etanol $100 \%$;

g) adicionar $1 \mu \mathrm{L}$ de solução de glicogênio $(20 \mathrm{mg} / \mathrm{mL})$; 
h) incubar, overnight, a $-20^{\circ} \mathrm{C}$;

i) centrifugar por 15 minutos a $13.200 \mathrm{rpm}$;

j) retirar o sobrenadante com cuidado e descartá-lo;

k) adicionar $1 \mathrm{~mL}$ de etanol 70\% gelado e homogeneizar;

1) centrifugar por 15 minutos a $13.200 \mathrm{rpm}$;

m) retirar o sobrenadante com cuidado e descartá-lo;

n) repete-se os passos “k", "l" e "m" duas vezes;

o) deixar o DNA secando a temperatura ambiente;

p) ressuspender o pellet com $20 \mu \mathrm{L}$ de água destilada livre de DNAse e RNAse (GIBCO BRL®);

q) incubar, overnight, a $4^{\circ} \mathrm{C}$.

O DNA da linhagem celular HCT 116 foi extraído pela técnica do Fenol Clorofórmio $^{33}$ adaptada. Já para a extração do DNA das linhagens H 1299 e MCF-7 foi utilizado o Kit Perfect gDNA Blood Mini (Eppendorf).

\subsubsection{Tratamento com bissulfito de sódio e PCR (MSP)}

Após a extração do DNA, todas as amostras tumorais (tecidos parafinados e linhagens celulares) e as hiperplasias fibrosas foram submetidas ao tratamento com bissulfito de sódio e subseqüente PCR (MSP) conforme descrito por GOLDENBERG et al. ${ }^{37}$. No MSP, o DNA é tratado com bissulfito de sódio que possui a capacidade da agir sobre as citosinas não metiladas da molécula de DNA e transformá-las em uracilas através de uma reação simples de deaminação. As citosinas metiladas não são convertidas em uracila após o tratamento com esse reagente, assim, pode-se diferenciar entre as citosinas que possuem um grupamento metil 
ligado no carbono 5 e as citosinas que não o possuem (Figura 2). Após o tratamento, uma reação de PCR é realizada utilizando-se primers específicos para o DNA modificado.

\section{CpG metilado é resistente ao tratamento com bissulfito de sódio}

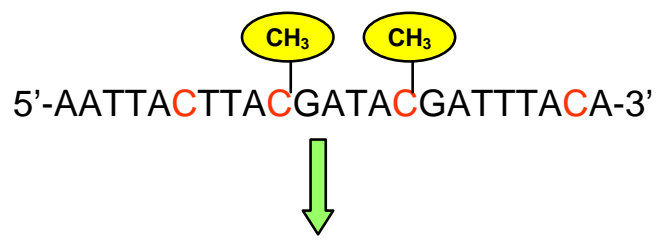

5'-AATTAUTTACGATACGATTTAUA-3'

CpG não metilado é sensível ao tratamento com bissulfito de sódio

5'-AATTACTTACGATACGATTTACA-3'<smiles>[C]=C</smiles>

5'-AATTAUTTAUGATAUGATTTAUA-3'

Após a PCR, as uracilas são substituídas por timinas e as citosinas são mantidas

5'-AATTAUTTACGATACGATTTAUA-3'<smiles></smiles><smiles>CCCCCCC</smiles>

5'-AATTATTTACGATACGATTTATA-3'

3'-TTAATAAATGCTATGCTAAATAT-5'
5'-AATTAUTTAUGATAUGATTTAUA-3'<smiles>[R][Y]=C</smiles>

5'-AATTATTTATGATATGATTTATA-3' 3'-TTAATAAATACTATACTAAATAT-5' 
FIGURA 2 - Representação esquemática do tratamento do DNA com o reagente bissulfito de sódio. Adaptada de $\operatorname{COSTA}^{22}$, 2004 
Para cada $20 \mu \mathrm{L}$ da solução obtida na extração do DNA, realizou-se o tratamento com bissulfito de sódio, que resumidamente consiste:

1) Primeira etapa - desnaturação do DNA:

a) adicionar $2 \mu \mathrm{L}$ de $\mathrm{NaOH}(3,0 \mathrm{M})$;

b) adicionar $1 \mu \mathrm{L}(10 \mathrm{mg} / \mathrm{mL})$ de DNA de esperma de Arenque (DNA Typing GRADE TM Hering Sperm DNA - GIBCO BRL ${ }^{\circledR)}$;

c) incubar por 20 minutos a $50^{\circ} \mathrm{C}$.

2) Segunda etapa - tratamento com bissulfito de sódio (para oito amostras):

a) preparar 2,5mL solução de bissulfito de sódio (3M) e acrescentar:

- $\quad 700 \mu \mathrm{L}$ de $\mathrm{NaOH}(2 \mathrm{M})$;

- $\quad 500 \mu \mathrm{L}$ de solução de hidroquinona (1M);

b) adicionar $500 \mu \mathrm{L}$ da solução bissulfito/hidroquinona/ $\mathrm{NaOH}$ na solução do DNA desnaturado;

c) incubar por três horas a $70^{\circ} \mathrm{C}$;

d) adicionar $1 \mathrm{~mL}$ de Resina (Wizard ${ }^{\circledR}$ DNA Clean-up Resin utilização do kit Wizard® DNA Clean-up System, PROMEGA);

e) homogeneizar por inversão;

f) filtrar a Resina com DNA ligado por uma coluna (kit Wizard ${ }^{\circledR}$ DNA Clean-up System, PROMEGA);

g) lavar a coluna com $2 \mathrm{~mL}$ de isopropanol $80 \%$, repetir este procedimento duas vezes;

h) centrifugar a coluna conectada no tubo de microcentrífuga $1,5 \mathrm{~mL}$ por três minutos a $13.200 \mathrm{rpm}$; 
i) transferir a coluna para um novo tubo e eluir o DNA tratado adicionando $45 \mu \mathrm{L}$ de água pré-aquecida $\left(80^{\circ} \mathrm{C}\right)$;

j) aguardar por um minuto à temperatura ambiente;

k) centrifugar por três minutos a 13.200rpm;

1) descartar a coluna;

m) adicionar $5 \mu \mathrm{L}$ de $\mathrm{NaOH}(3 \mathrm{M})$ e deixar à temperatura ambiente por dez minutos;

3) Terceira etapa - precipitação do DNA:

a) adicionar $75 \mu \mathrm{L}$ de acetato de amônio (5M) e aguardar cinco minutos;

b) adicionar $350 \mu \mathrm{L}$ de etanol $100 \%$;

c) adicionar $1 \mu \mathrm{L}$ de solução de glicogênio $(20 \mathrm{mg} / \mathrm{mL})$;

d) incubar, overnight, a $-20^{\circ} \mathrm{C}$;

e) centrifugar por quinze minutos a $13.200 \mathrm{rpm}$;

f) retirar e descartar o sobrenadante com cuidado;

g) adicionar $500 \mu \mathrm{L}$ de etanol $70 \%$;

h) centrifugar por 15 minutos a $13.200 \mathrm{rpm}$;

i) retirar o sobrenadante com cuidado;

j) secar o precipitado à temperatura ambiente;

k) ressuspender em $25 \mu \mathrm{L}$ de água destilada livre de DNAse e RNAse (GIBCO BRL®);

1) armazenar a $-80^{\circ} \mathrm{C}$ até o uso. 


\subsubsection{Reação de PCR}

Realizou-se uma reação de PCR específica para detecção de metilação (MSP methylation specific PCR). A técnica de MSP é muito sensível, sendo capaz de detectar um alelo que apresenta metilação dentre mil que se apresentam não metilados ${ }^{37,42,102}$.

Foram utilizados dois pares de primers capazes de distinguir as amostras metiladas das não metiladas, levando-se em consideração a modificação dos nucleotídeos pelo bissulfito de sódio. As seqüências dos primers para a região promotora do gene da E-caderina foram obtidas de ZÖCHBAUER-MÜLLER et al. ${ }^{102}, 2001$ :

\begin{tabular}{|c|c|c|}
\hline Gene & $\begin{array}{c}\text { Seqüências dos primers para a situação } \\
\text { metilada (5'-3') }\end{array}$ & $\begin{array}{c}\text { Seqüências dos primers para a situação } \\
\text { não metilada (5'- } \mathbf{3}^{\prime} \text { ) }\end{array}$ \\
\hline E-cad & D $^{*}$ TTAGGTTAGAGGGTTATCGCGT & D* TAATTTTAGGTTAGAGGGTTATTGT \\
& $\mathrm{R}^{* *}$ TAACTAAAAATTCACCTACCGAC & $\mathrm{R}^{* *}$ CACAACCAATCAACAACACA \\
\hline
\end{tabular}

${ }^{*}$ Primer direto, ${ }^{* *}$ Primer reverso

Dessa forma, duas reações de PCR separadas (uma para a situação metilada e outra para a situação não metilada) são realizadas e a presença de metilação em uma seqüência de nucleotídeos pode ser verificada. As condições de PCR utilizadas foram:
a) 0,2mM de dNTPs;
b) $0,4 \mu \mathrm{M}$ de primer direto;
c) $0,4 \mu \mathrm{M}$ de primer reverso;
d) 1,5u de Platinum ${ }^{\circledR}$ Taq DNA Polimerase (Invitrogen);
e) 2,0mM de $\mathrm{MgCl}_{2}$ (Invitrogen); 
f) $1 \mathrm{X}$ de Tampão de Reação para Platinum ${ }^{\circledR}$ Taq DNA Polimerase (Invitrogen);

g) DMSO 5\%;

h) totalizando $24 \mu \mathrm{L}$, onde era adicionado $1 \mu \mathrm{L}$ de DNA previamente tratado com bissulfito de sódio.

As melhores condições observadas de amplificação envolveram três etapas nas quais a temperatura de anelamento era mais alta nos dez primeiros ciclos e diminuída de dois graus na etapa seguinte (dez ciclos) e outros dois graus nos últimos 15 ciclos. Devido à maior temperatura nos primeiros ciclos assegurava-se uma maior especificidade de amplificação, e com a diminuição da temperatura nos ciclos seguintes obtinha-se um maior rendimento de amplificação do produto específico. Em razão das diferenças na temperatura de anelamento dos primers para a região promotora do gene da E-caderina e também para especificar a amplificação, foram utilizadas duas condições de $\mathrm{PCR}$, em relação à temperatura de anelamento, sendo uma para a reação metilada e outra para a reação não metilada. Assim sendo, o programa de PCR apresentava:

1) Reação metilada:

a) cinco minutos iniciais a $94^{\circ} \mathrm{C}$ para a ativação da enzima Platinum ${ }^{\circledR}$ Taq DNA Polimerase (Invitrogen);

b) dez ciclos: de 30 segundos a $94^{\circ} \mathrm{C}$, um minuto a $64^{\circ} \mathrm{C}$ e um minuto a $72^{\circ} \mathrm{C}$;

c) dez ciclos: de 30 segundos a $94^{\circ} \mathrm{C}$, um minuto a $62^{\circ} \mathrm{C}$ e um minuto a $72^{\circ} \mathrm{C}$;

d) quinze ciclos: de 30 segundos a $94^{\circ} \mathrm{C}$, um minuto a $60^{\circ} \mathrm{C}$ e um minuto a $72^{\circ} \mathrm{C}$; 
e) sete minutos a $72^{\circ} \mathrm{C}$.

2) Reação não metilada:

a) cinco minutos iniciais a $94^{\circ} \mathrm{C}$ para a ativação da enzima Platinum ${ }^{\circledR}$ Taq DNA Polimerase (Invitrogen);

b) dez ciclos: de 30 segundos a $94^{\circ} \mathrm{C}$, um minuto a $62^{\circ} \mathrm{C}$ e um minuto a $72^{\circ} \mathrm{C}$;

c) dez ciclos: de 30 segundos a $94^{\circ} \mathrm{C}$, um minuto a $60^{\circ} \mathrm{C}$ e um minuto a $72^{\circ} \mathrm{C}$;

d) 15 ciclos: de trinta segundos a $94^{\circ} \mathrm{C}$, um minuto a $58^{\circ} \mathrm{C}$ e um minuto a $72^{\circ} \mathrm{C}$;

e) sete minutos a $72^{\circ} \mathrm{C}$.

Para a detecção dos produtos amplificados, as amostras foram aplicadas em gel de poliacrilamida $8 \%$ e coradas com nitrato de $\operatorname{prata}^{74}$.

\subsection{Método imuno-histoquímico}

As marcações imuno-histoquímicas dos espécimes tumorais nos três grupos estudados e nas hiperplasias fibrosas seguiram os protocolos de reações utilizados no Setor de Imuno-histoquímica em Pesquisa do Centro de Pesquisa da Fundação Antonio Prudente, São Paulo-SP, utilizando-se da técnica estreptavidina-biotina-peroxidase para o anticorpo da Ecaderina (clone 36, BD Transduction, código C20820, título preestabelecido 1:700).

As reações foram realizadas observando-se o seguinte protocolo:

Desparafinização dos cortes de $3 \mu \mathrm{m}$ de espessura em lâminas Superfrost Plus, (Erviegas), deixando-as por 24 horas em estufa à temperatura de $60^{\circ} \mathrm{C}$, em xilol a $60^{\circ} \mathrm{C}$ e em 
xilol a temperatura ambiente por 20 minutos cada. Em seguida, os cortes foram hidratados em etanol em concentrações decrescentes e lavados em água corrente e destilada.

A recuperação antigênica para a marcação imuno-histoquímica dos anticorpos foi realizada por meio da incubação dos espécimes em solução tampão citrato $10 \mathrm{mM}$ pH 6,0 , usando uma panela de pressão como fonte geradora de calor úmido por quatro minutos. Resfriamento por dez minutos sob água corrente e dez minutos a temperatura ambiente sem a tampa. Lavagem das lâminas em água corrente e destilada e posterior bloqueio da peroxidase endógena com Água Oxigenada (dez volumes), realizando-se quatro trocas de cinco minutos cada. Após este bloqueio, as lâminas foram novamente lavadas em água corrente e destilada e com solução salina tamponada com fosfato (PBS- phosphate buffered saline) $10 \mathrm{mM} \mathrm{pH} \mathrm{7,4,}$ por cinco minutos.

Os espécimes foram incubados com os anticorpos primários diluídos em tampão PBS contendo albumina bovina, BSA 1\% (Sigma, A9647, EUA) e azida sódica $\left(\mathrm{NaN}_{3}\right)$ 0,1\%, por 18 horas a $4^{\circ} \mathrm{C}$ em câmara úmida.

Os espécimes foram então incubados com o anticorpo secundário biotiniladoreagente C (Biotinylated affinity-isolated goat antimouse/rabbit Ig) do kit de detecção StreptABComplex/HRP Duet (mouse/rabbit), Dako A/S K0492, Dinamarca, em título preestabelecido de 1:200, diluído em PBS, por um período de 30 minutos a $37^{\circ} \mathrm{C}$. Posteriormente, foram incubados com o complexo reagente A (Streptavidin) e reagente B (biotinylated peroxidase) desse mesmo kit em título preestabelecido de 1:200 por 30 minutos a $37^{\circ} \mathrm{C}$.

O produto final da reação antígeno-anticorpo foi visualizado por meio da incubação dos espécimes em solução substrato cromógeno 3,3' Diaminobezidine Tetrahydrochloride 
60mg\% (Sigma D-5637 EUA); Dimetilsulfóxido 1mL; $\mathrm{H}_{2} \mathrm{O}_{2}$ 6\% (20 volumes) 1mL, PBS $100 \mathrm{~mL}$, por cinco minutos a $37^{\circ} \mathrm{C}$, ao abrigo da luz.

Os espécimes foram contracorados com solução de Hematoxilina de Harris por um minuto e em seguida desidratados e montados com a utilização de resina adesiva Entellan Neu (Merck 1,07961 Alemanha) e lamínulas.

Utilizou-se como controle positivo um espécime de dermatofibroma e como controle negativo um corte representativo destes tecidos com omissão do anticorpo primário específico nos procedimentos imuno-histoquímicos.

\subsection{Avaliação imuno-histoquímica}

O anticorpo E-caderina nos espécimes de CV, CEC-pN0, CEC-pN+ foi avaliado individualmente por meio de um sistema computadorizado de captura de imagens da região do front de invasão tumoral. Um total de seis campos microscópicos de cada espécime tumoral analisada (9 CVs, 20 CECs-pN0, 17 CECs-pN+) foi capturado a partir de uma câmera digital Sony Cyber-Shot (3.3 mega pixels), acoplada ao microscópio Zeiss Axioskop 40, com objetiva de 40X. Esta câmera encontrava-se conectada a um microcomputador Pentium III Fujitsu contendo um sistema de processamento e análise de imagens (Axiovision Zeiss). Cada imagem microscópica capturada pelo programa correspondia a uma área de $34.477,83 \mu \mathrm{m}^{2}$. O valor total da área dos seis campos analisados, na região do front de invasão tumoral de cada espécime correspondia a $206.866,98 \mu \mathrm{m}^{2}$.

A avaliação da expressão do anticorpo da E-caderina foi realizada a partir da quantificação da porcentagem de células tumorais positivas que continham marcação completa da membrana citoplasmática, determinadas pela coloração acastanhada da membrana; as células que possuíam marcação incompleta ou ausente foram consideradas negativas. A partir 
do valor mediano de marcação obtido para o anticorpo nos três grupos de carcinomas $(\mathrm{CV}$, CEC-pN0 e CEC-pN+), codificaram-se as variáveis contínuas em variáveis categóricas. Para avaliação da expressão do anticorpo E-caderina utilizou-se das categorias $\leq 36,5 \%$ e $>36,5 \%$ de marcações positivas.

\subsection{Análise estatística}

Os registros das informações clínicas e microscópicas dos pacientes com CV, e os dados relativos à expressão imuno-histoquímica e da hipermetilação do gene da caderina nos três grupos de carcinomas analisados (CV, CEC-pN0 e CEC-pN+) foram armazenados num banco de dados, elaborado em planilha do Microsoft Excel. As análises estatísticas foram realizadas utilizando-se o programa para microcomputador STATA versão 7.0 (StataCorp. $2001)^{83}$

Estatísticas descritivas de distribuição de freqüências e de medidas de tendência central e de variabilidade foram utilizadas para caracterizar a casuística.

Para verificar a associação entre os grupos estudados com relação às variáveis categóricas, o teste de freqüências do quiquadrado foi utilizado quando possível e, em tabelas 2x2 onde pelo menos uma freqüência esperada foi menor que 5 o teste exato de Fisher foi preferido.

O teste não paramétrico de Kruskal-Wallis foi adotado para verificar a associação entre as variáveis numéricas em relação aos grupos.

A análise de sobrevida foi realizada utilizando-se a técnica de Kaplan-Meier e as curvas de sobrevida entre os grupos foram comparadas através do teste de logrank.

O tempo de seguimento foi calculado entre a data da cirurgia até a data do óbito ou a data do último follow-up para os pacientes que foram considerados censurados, ou seja, os que 
estavam vivos ou perdidos de seguimento. O tempo de seguimento da sobrevida livre de doença foi considerado da data da cirurgia até a data da ocorrência de recidiva local, ou regional ou da metástase.

Para todos os testes estatísticos adotou-se o nível de significância de 5\%.

\subsection{Registro fotográfico}

Os campos microscópicos tumorais mais representativos do grupo CV corados pela HE e dos três grupos de carcinomas de boca (CV, CEC-pN0 e CEC-pN+) imunomarcados (Ecaderina) foram registrados a partir de uma câmera digital Sony Cyber-Shot (3.3 mega pixels), acoplada ao microscópio Zeiss Axioskop 40. Esta câmera encontrava-se conectada a um microcomputador Pentium III Fujitsu.

\subsection{Questões éticas}

Este estudo foi aprovado pela Comissão de Ética em Pesquisa (CEP) do Hospital do Câncer A.C. Camargo, em reunião de 25 de março de 2003, Projeto de Pesquisa n ${ }^{0}$ 480/03. 
5 RESULTADOS 


\section{RESULTADOS}

\subsection{Carcinoma verrucoso}

\subsubsection{Casuística}

Realizou-se inicialmente um levantamento dos carcinomas verrucosos e espinocelulares de boca no banco de dados do Departamento de Cirurgia de Cabeça e Pescoço e Otorrinolaringologia e do Departamento de Anatomia Patológica do Hospital do Câncer, no período de 1980 a 2000. Um total de 1613 espécimes, corados pela Hematoxilina e Eosina, diagnosticados como carcinomas verrucosos e espinocelulares primários localizados na língua, soalho bucal, gengiva superior e inferior, área retromolar, palato mole e palato duro, mucosa jugal, lábio superior e inferior foi analisado, revelando uma freqüência de dez carcinomas verrucosos $(0,6 \%)$ e 1358 carcinomas espinocelulares bem diferenciados (Tabela 1).

TABELA 1 - Distribuição dos carcinomas verrucosos e carcinomas espinocelulares de boca quanto aos critérios de inclusão estabelecidos. Hospital do Câncer, São Paulo, 1980 a 2000

\begin{tabular}{lcc}
\hline \hline GRUPO & № & \% \\
\hline Carcinoma verrucoso & 10 & 0,6 \\
Carcinoma espinocelular bem diferenciado & 1358 & 84,2 \\
Carcinoma espinocelular moderadamente/pouco Diferenciado & 245 & 15,2 \\
\hline TOTAL & $\mathbf{1 6 1 3}$ & $\mathbf{1 0 0 , 0}$ \\
\hline \hline
\end{tabular}




\subsubsection{Caracterização demográfica e clínica da população de estudo}

A análise dos pacientes com carcinoma verrucoso de boca revelou um maior comprometimento dos pacientes do gênero masculino (60\%) e da raça branca (90\%). Apenas um paciente da raça negra foi identificado como pode ser observado na Tabela 2.

A idade mínima obtida na época do diagnóstico do carcinoma verrucoso bucal foi de 41 anos e a máxima 83 anos (idade média de 67,8 e desvio padrão 14,40). A maioria dos pacientes apresentava idade acima de 67anos (60\%) como pode ser visualizado na Tabela 2.

$\mathrm{Na}$ amostra estudada, os locais mais freqüentemente acometidos pelo carcinoma verrucoso bucal foram o lábio inferior (40\%) seguido pela gengiva inferior $(20 \%)$ e palato duro (20\%). Regiões como mucosa jugal e palato mole também foram afetadas pelo carcinoma verrucoso (Tabela 2). Em 80\% dos espécimes, o tumor apresentava-se restrito ao seu local de origem, enquanto que em dois pacientes a lesão se estendia para áreas anatômicas adjacentes. 
TABELA 2 - Distribuição de freqüência dos pacientes acometidos pelo carcinoma verrucoso de boca segundo as características demográficas e localização da lesão. Hospital do Câncer, São Paulo, 1980 a 2000

\begin{tabular}{lcc}
\hline \hline Características & № de pacientes & \% \\
\hline Gênero & 6 & 60 \\
Masculino & 4 & 40 \\
Feminino & & \\
Raça & 9 & 90 \\
Branca & 1 & 10 \\
Não Branca & & \\
Idade & 4 & 40 \\
$\leq 67$ anos & 6 & 60 \\
$>$ 67 anos & & \\
Localização & 4 & 40 \\
Lábio inferior & 2 & 20 \\
Gengiva inferior & 2 & 10 \\
Palato duro & 1 & $\mathbf{1 0 0 , 0}$ \\
Mucosa jugal & 10 & \\
Palato mole & & 20 \\
\hline TOTAL & & 10 \\
\hline \hline
\end{tabular}

O tabagismo e o etilismo foram fatores de riscos constantemente observados na amostra estudada, sendo relatados por $60 \%$ e $90 \%$ dos pacientes, respectivamente. Um aspecto interessante foi que todos os pacientes tabagistas com carcinoma verrucoso eram etilistas e nem todos etilistas eram tabagistas (Tabela 3). Entre os tabagistas, 5 pacientes fumavam cigarros de papel e um paciente fazia uso de cachimbo. 
Três indíviduos (30\%) não eram tabagistas e em um paciente as informações relativas ao tabagismo e etilismo eram desconhecidas como pode ser observado na Tabela 3.

O tempo de história clínica (Tabela 3) foi registrado em oito dos dez pacientes com carcinoma verrucoso bucal, sendo o mínimo observado de um mês e o máximo de 60 meses (tempo médio 16,12 e desvio padrão 20,92).

TABELA 3 - Distribuição de freqüência dos pacientes acometidos pelo carcinoma verrucoso de boca segundo os fatores de risco e a história clínica. Hospital do Câncer, São Paulo, 1980 a 2000

\begin{tabular}{|c|c|c|}
\hline Características & № de pacientes & $\%$ \\
\hline \multicolumn{3}{|l|}{ Tabagismo } \\
\hline Não & 3 & 30 \\
\hline $\operatorname{Sim}$ & 6 & 60 \\
\hline Desconhecido & 1 & 10 \\
\hline \multicolumn{3}{|l|}{ Etilismo } \\
\hline Não & - & - \\
\hline Sim & 9 & 90 \\
\hline Desconhecido & 1 & 10 \\
\hline \multicolumn{3}{|c|}{ Tabagismo + etilismo } \\
\hline Sim & 6 & 60 \\
\hline Não & 3 & 30 \\
\hline Desconhecido & 1 & 10 \\
\hline \multicolumn{3}{|c|}{ Tempo de história clínica } \\
\hline$\geq 16$ meses & 6 & 60 \\
\hline$<16$ meses & 2 & 20 \\
\hline Desconhecido & 2 & 20 \\
\hline TOTAL & 10 & 100,0 \\
\hline
\end{tabular}


A análise clínica dos pacientes com carcinoma verrucoso bucal revelou que, no momento do diagnóstico, os pacientes apresentaram estadios clínicos iniciais (I-II). Quanto ao estadiamento clínico T, 60\% dos pacientes apresentaram tumores classificados como T1 e $40 \%$ como T2, adotando-se os critérios de estadiamento clínico definido pela $\mathrm{UICC}^{40}$. Verificou-se que nenhum destes pacientes apresentou linfonodos regionais clinicamente palpáveis no momento do diagnóstico. Clinicamente, $80 \%$ dos CVs apresentaram aspecto ulcerovegetante e $20 \%$ outro aspecto, do tipo nodular (Tabela 4 ).

TABELA 4 - Distribuição de freqüência dos pacientes acometidos pelo carcinoma verrucoso de boca, segundo as características clínicas da lesão e o estadiamento clínico. Hospital do Câncer, São Paulo, 1980 a 2000

\begin{tabular}{lll}
\hline \hline Características & № de pacientes & $\%$ \\
\hline
\end{tabular}

\section{Tipo de lesão}

Ulcerovegetante

$8 \quad 80$

Ulceroinfiltrativo

Outro aspecto

2

20

\section{Estadiamento T}

$\mathrm{T} 1$

$\mathrm{T} 2$
6

4
60

40

\section{Estadiamento N}

\begin{tabular}{ccc} 
N0 & 10 & 100 \\
\hline TOTAL & $\mathbf{1 0}$ & $\mathbf{1 0 0 , 0}$ \\
\hline \hline
\end{tabular}

De acordo com os critérios de inclusão dos pacientes no estudo, $100 \%$ foram submetidos à cirurgia como tratamento inicial do carcinoma verrucoso bucal. Em nenhum destes pacientes foi realizado esvaziamento cervical, radioterapia e/ou quimioterapia pósoperatória adjuvante (Tabela 5). 
A ocorrência de recidiva local foi observada em $40 \%$ dos pacientes, não sendo verificados recidiva regional e/ou desenvolvimento de metástases a distância. Constatou-se o desenvolvimento de um segundo tumor primário em $20 \%$ dos pacientes e as lesões ocorreram na área retromolar e mucosa jugal.

TABELA 5 - Distribuição de freqüência dos pacientes acometidos pelo carcinoma verrucoso de boca, segundo o tratamento e a evolução clínica. Hospital do Câncer, São Paulo, 1980 a 2000

\begin{tabular}{lcc}
\hline \hline Características & № de pacientes & $\%$ \\
\hline Esvaziamento cervical & & \\
Não & 10 & 100 \\
Sim & 0 & 0
\end{tabular}

\section{Radioterapia}

Não

$10 \quad 100$

Sim

0

0

\section{Quimioterapia}

Não

$10 \quad 100$

Sim

0

0

\section{Recidiva local}

Não

60

Sim

4

40

\section{Segundo tumor}

\begin{tabular}{ccc} 
Não & 8 & 80 \\
Sim & 2 & 20 \\
\hline TOTAL & $\mathbf{1 0}$ & $\mathbf{1 0 0 , 0}$ \\
\hline \hline
\end{tabular}

Ao final do período de seguimento, quatro pacientes (40\%) estavam vivos e sem evidências de recidiva da doença, três $(30 \%)$ morreram por outras causas não relacionadas ao 
tumor e três $(30 \%)$ apresentavam menos de cinco anos de seguimento e foram considerados perdidos de vista. A sobrevida global foi de cinco anos para $87,5 \%$ e dez anos para $70 \%$ dos pacientes. A sobrevida livre de doença foi de cinco anos para $65,6 \%$ e dez anos para 52,5\% dos pacientes.

\subsubsection{Análise microscópica morfológica}

As alterações microscópicas epiteliais observadas no carcinoma verrucoso bucal foram discretas e características desta neoplasia como pode ser observado na Tabela 6 .

As lesões eram exofíticas, verrucosas com fendas epiteliais preenchidas por queratina, formando verdadeiros "tampões de queratina". O tecido epitelial apresentava-se hiperplásico, com discreto e/ou moderado hipercromatismo e com acantose intensa em 80\% dos espécimes (Tabela 6 e Figura 3). Poucas figuras de mitoses foram identificadas e um moderado pleomorfismo celular foi observado em 50\% dos carcinomas verrucosos (Figura 4).

As cristas epiteliais interpapilares eram largas e longas e pareciam "empurrar" o tecido conjuntivo adjacente. O padrão de invasão compressivo com membrana basal íntegra foi observado na grande maioria dos espécimes analisados (Tabela 6 e Figuras 3 e 4).

No tecido conjuntivo adjacente, o aspecto mais relevante foi a presença de um discreto infiltrado inflamatório mononuclear observado em 50\% dos espécimes (Tabela 6 e Figuras 3 e 4). Este infiltrado era predominantemente difuso e estava localizado tanto no tecido epitelial quanto conjuntivo (Figura 5). Em 40\% dos espécimes foram observadas células inflamatórias polimorfonucleares (Tabela 6 e Figura 5).

Embolização vascular e/ou linfática e infiltração dos tecidos neurais, musculares, ósseos e glandulares não foram observados.

As margens cirúrgicas estavam livres em todos os espécimes analisados. 
TABELA 6 - Distribuição de freqüência dos pacientes acometidos pelo carcinoma verrucoso de boca, segundo as características microscópicas. Hospital do Câncer, São Paulo, 1980 a 2000

\begin{tabular}{|c|c|c|}
\hline Características & № de pacientes & $\%$ \\
\hline \multicolumn{3}{|c|}{ Hipercromatismo } \\
\hline Discreto & 4 & 40 \\
\hline Moderado & 5 & 50 \\
\hline Intenso & 1 & 10 \\
\hline \multicolumn{3}{|c|}{ Pleomorfismo nuclear } \\
\hline Discreto & 2 & 20 \\
\hline Moderado & 5 & 50 \\
\hline Intenso & 3 & 30 \\
\hline \multicolumn{3}{|l|}{ Queratinização } \\
\hline Discreta & 0 & 0 \\
\hline Moderada & 2 & 20 \\
\hline Intensa & 8 & 80 \\
\hline \multicolumn{3}{|l|}{ Disqueratose } \\
\hline Discreto & 2 & 20 \\
\hline Moderado & 5 & 50 \\
\hline Intenso & 3 & 30 \\
\hline \multicolumn{3}{|l|}{ Acantose } \\
\hline Discreta & 0 & 0 \\
\hline Moderada & 2 & 20 \\
\hline Intensa & 8 & 80 \\
\hline \multicolumn{3}{|l|}{ Membrana basal } \\
\hline Íntegra & 9 & 90 \\
\hline Descontínua & 1 & 10 \\
\hline Rompida & 0 & 0 \\
\hline \multicolumn{3}{|c|}{ Infiltrado inflamatório } \\
\hline Focal & 4 & 40 \\
\hline Difuso & 6 & 60 \\
\hline \multicolumn{3}{|c|}{ Infiltrado inflamatório MNs } \\
\hline Discreto & 5 & 50 \\
\hline Moderado & 3 & 30 \\
\hline Intenso & 2 & 20 \\
\hline \multicolumn{3}{|c|}{ Infitrado inflamatório PMNs } \\
\hline Discreto & 6 & 60 \\
\hline Moderado & 2 & 20 \\
\hline Intenso & 2 & 20 \\
\hline TOTAL & 10 & 100,0 \\
\hline
\end{tabular}

PMN: polimorfonucleares

MN: mononucleares 

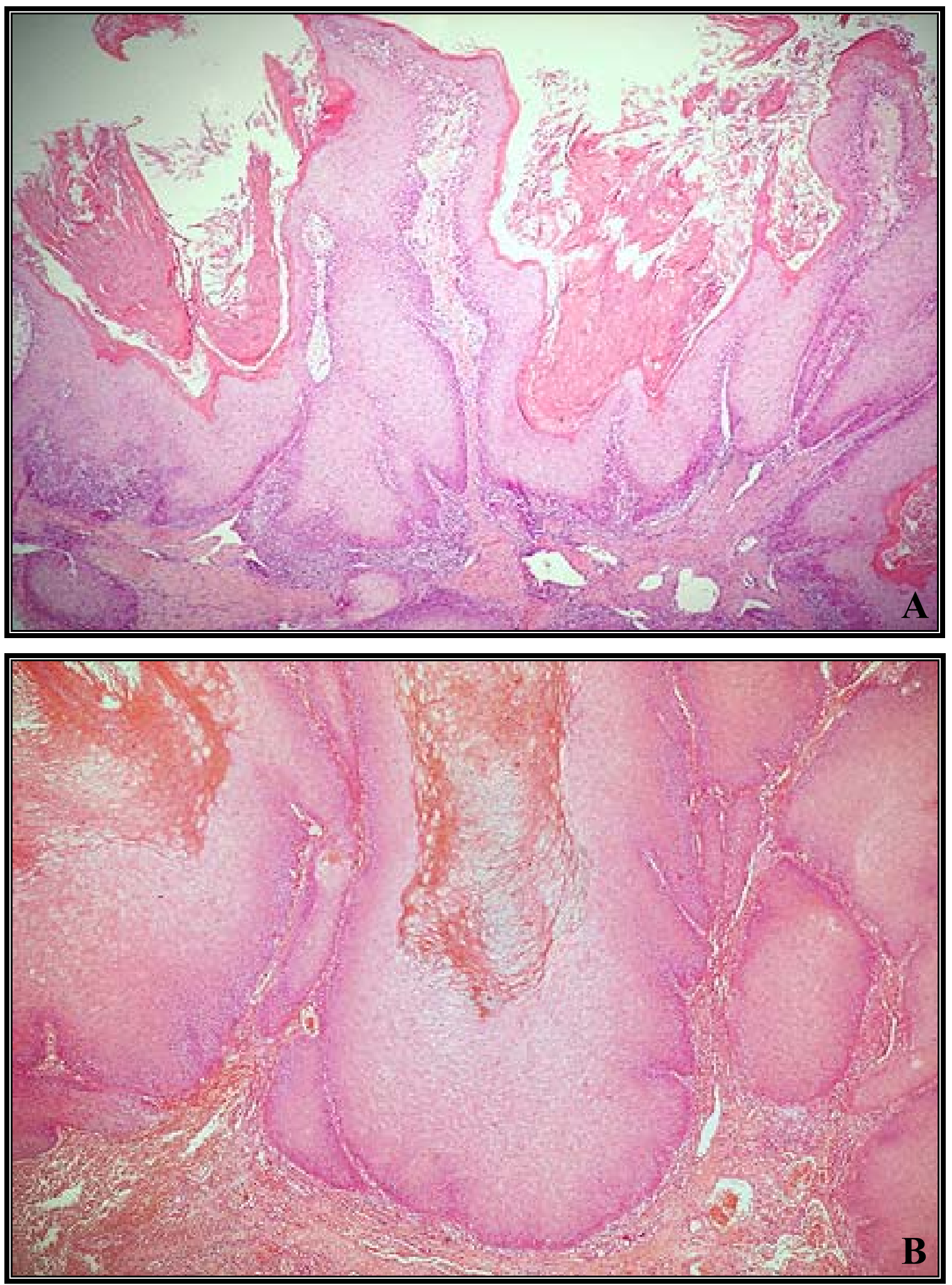

FIGURA 3 - A e B - CV bucal com intensa queratinização na superfície verrucosa, cristas epiteliais arredondadas, padrão compressivo e discreto infiltrado inflamatório no tecido conjuntivo. ( $\mathrm{HE}$, aumento original $\mathrm{A}$ e $\mathrm{B}=40 \mathrm{X}$ ) 

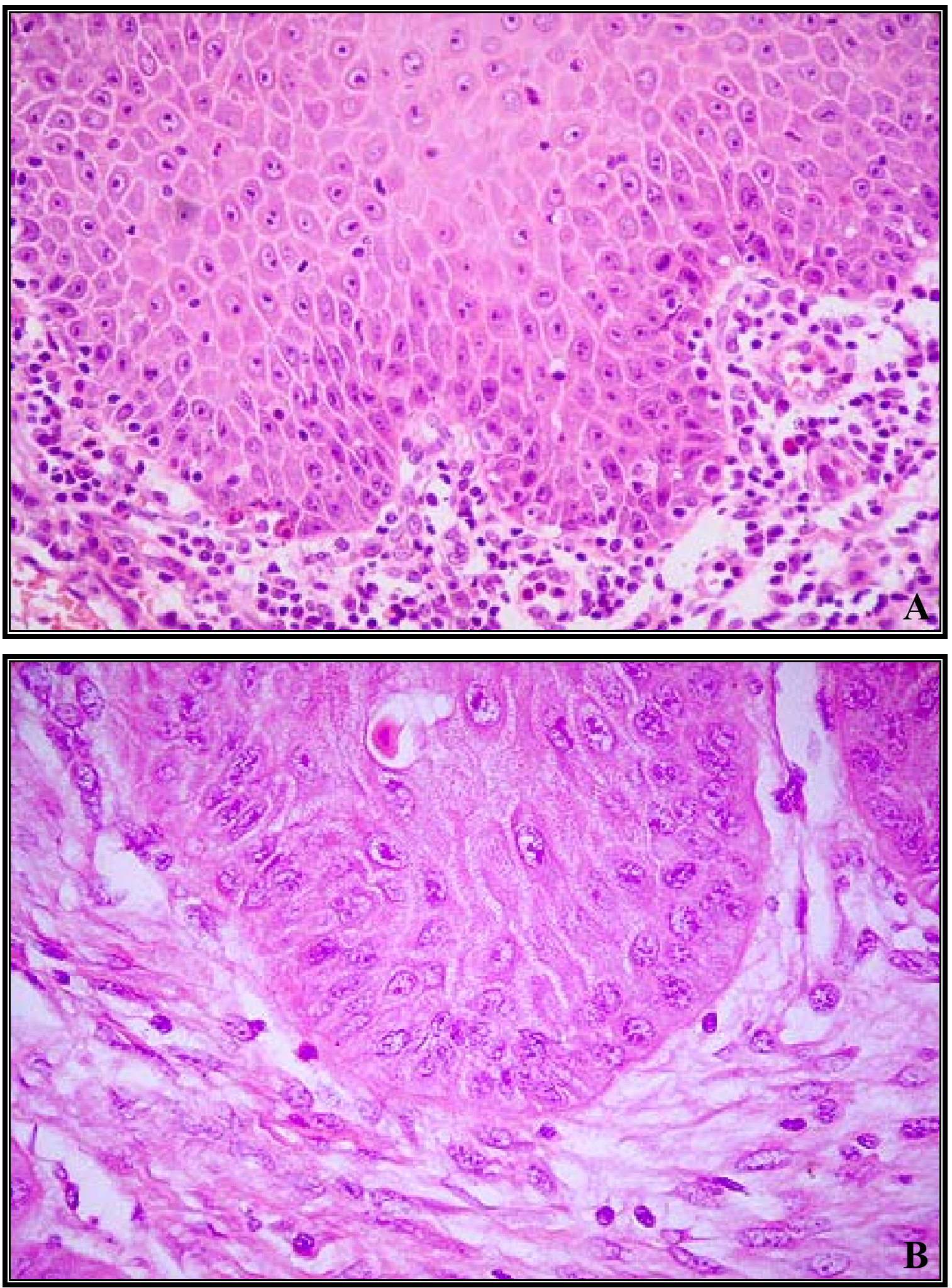

FIGURA 4 - CV bucal com discreto pleomorfismo celular, poucas figuras de mitoses e infiltrado inflamatório mononuclear subepitelial (A). Em B nota-se membrana basal íntegra na interface epitélio-conjuntivo. (HE, aumento original $\mathrm{A}$ e $\mathrm{B}=400 \mathrm{X}$ ) 

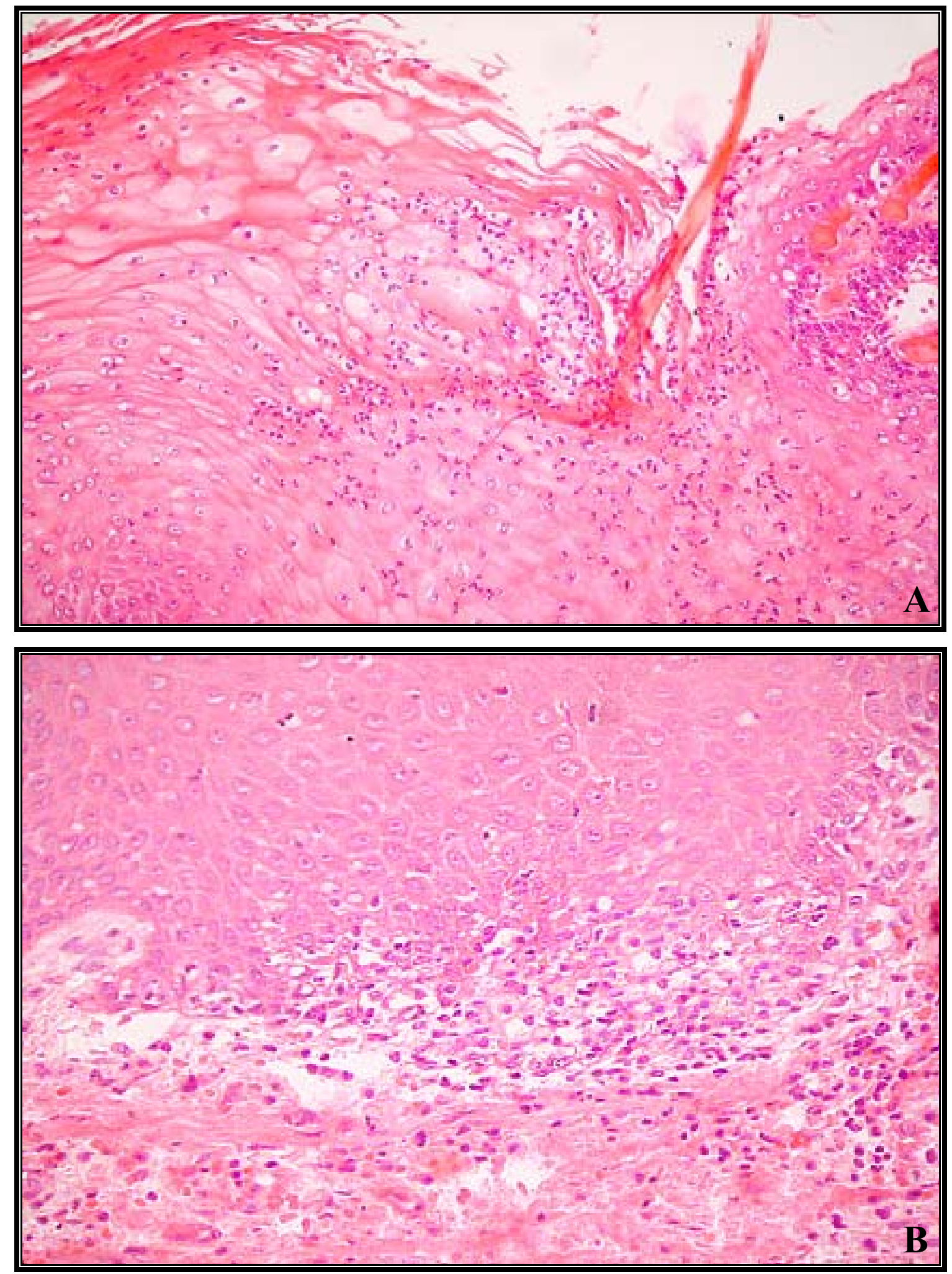

FIGURA $5-\mathrm{CV}$ bucal com intenso infiltrado inflamatório polimorfonucleares na superfície queratinizada (A). Em B, observa-se células inflamatórias crônicas invadindo e desorganizando a camada basal do epitélio. (HE, aumento original $\mathrm{A}=200 \mathrm{X}$ e $\mathrm{B}=400 \mathrm{X}$ ) 


\subsection{Análise da hipermetilação do gene da E-caderina nos carcinomas verrucosos e espinocelulares bem diferenciados de boca}

O perfil de metilação do gene da E-caderina foi estatisticamente semelhante $(p=$ 0,975) e superior a 50\% nos três grupos de carcinomas de boca (CV, CEC-pN0 e CEC-pN+), como pode ser observado na Tabela 7.

As cinco amostras de hiperplasias fibrosas (HFs) de mucosa bucal utilizadas como controle não apresentaram metilação do gene da E-caderina.

As Figuras 6 e 7 ilustram os diferentes padrões de metilação do gene da E-caderina observados nos grupos de carcinomas (CV, CEC-pN0 e CEC-pN+), hiperplasias fibrosas (HFs) e linhagens celulares.

TABELA 7 - Perfil da metilação do gene da E-caderina nos carcinomas verrucosos e carcinomas espinocelulares bem diferenciados de boca. Hospital do Câncer, São Paulo, 1980 a 2000

\begin{tabular}{|c|c|c|c|c|c|c|c|}
\hline \multirow{3}{*}{ E-caderina } & \multicolumn{6}{|c|}{ Grupo } & \multirow{3}{*}{$p^{*}$} \\
\hline & \multicolumn{2}{|c|}{ CV } & \multicolumn{2}{|c|}{ CEC-pNO } & \multicolumn{2}{|c|}{ CEC-pN+ } & \\
\hline & № & $\%$ & № & $\%$ & № & $\%$ & \\
\hline Metilado & 5 & 55,5 & 12 & 60 & 10 & 59 & \multirow{2}{*}{0,975} \\
\hline Não metilado & 4 & 44,5 & 8 & 40 & 7 & 41 & \\
\hline TOTAL & 9 & 100 & 20 & 100 & 17 & 100 & \\
\hline
\end{tabular}

CV: Carcinoma Verrucoso, CEC-pN0: Carcinoma Espinocelular Bem Diferenciado sem comprometimento linfonodal, CEC-pN+: Carcinoma Espinocelular Bem Diferenciado com comprometimento linfonodal

$p^{*}$ : valor obtido pelo teste do quiquadrado considerando-se nível de significância de $5 \%$ 

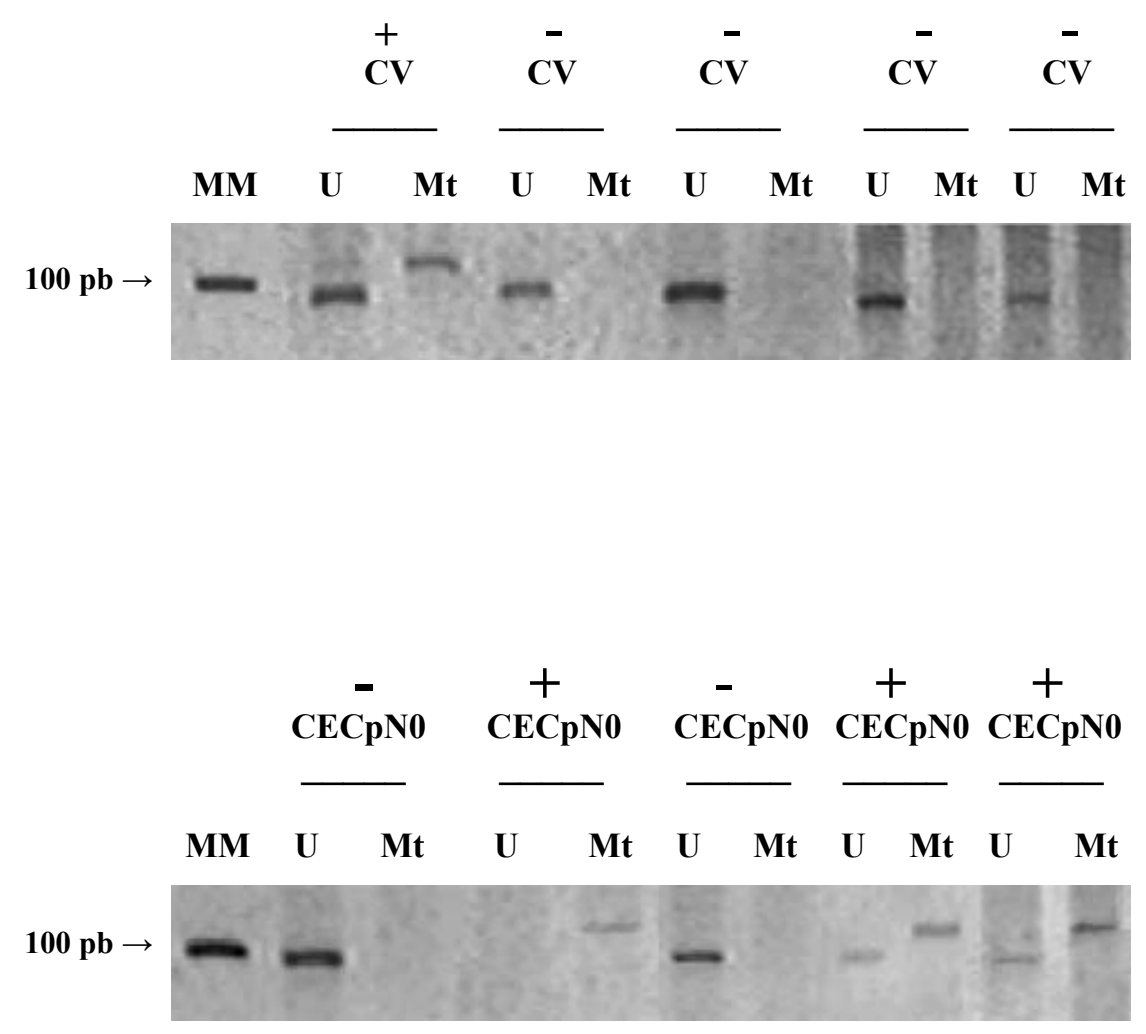

FIGURA 6 - Gel de poliacrilamida 8\% contendo reações de MSP com cinco amostras de carcinoma verrucoso (CV) e cinco amostras de carcinoma espinocelular bem diferenciado sem comprometimento linfonodal (CEC-pN0). MM - marcador de peso molecular 100pb, U: situação não metilada (97pb), Mt: situação metilada (115pb). Perfil de metilação: - não metilada, + metilada 

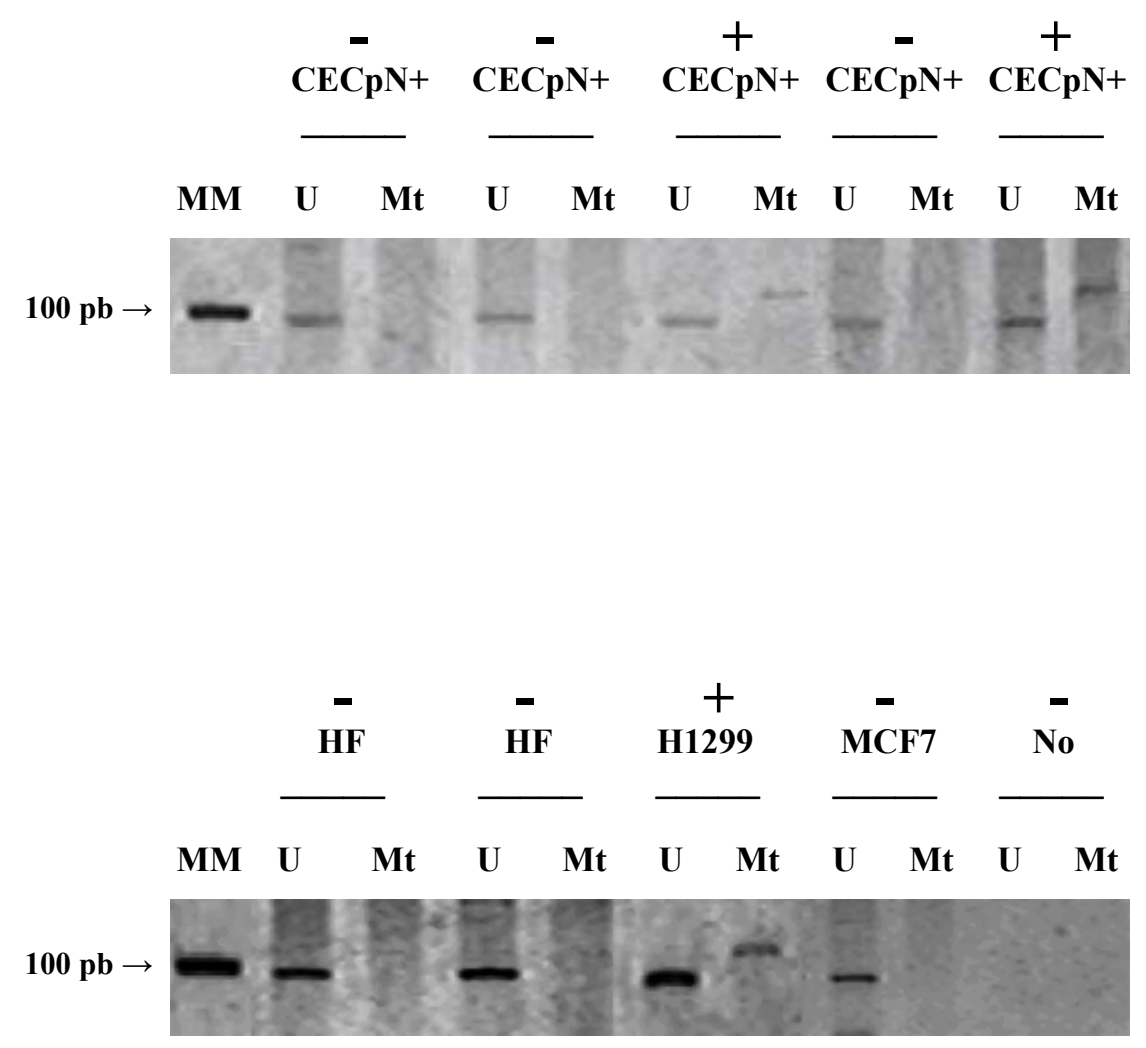

FIGURA 7 - Gel de poliacrilamida 8\% contendo reações de MSP com cinco amostras de carcinoma espinocelular bem diferenciado com comprometimento linfonodal $(\mathrm{CEC}-\mathrm{pN}+)$ e duas amostras de hiperplasia fibrosa (HF). Dois controles utilizados: um para a situação metilada (H 1299) e um para a situação não metilada (MCF-7). MM: marcador de peso molecular 100pb, No: controle sem DNA, U: situação não metilada (97pb), Mt: situação metilada (115pb). Perfil de metilação: - não metilada, + metilada 
A distribuição da hipermetilação do gene da E-caderina em relação às características clínicas analisadas nos diferentes grupos de carcinomas verrucosos e espinocelulares bem diferenciados estão descritas nas Tabelas 8, 9 e 10.

Quanto aos aspectos clínicos, uma maior freqüência de carcinomas espinocelulares bem diferenciados de boca com hipermetilação do gene da E-caderina (CEC-pN0 e CEC$\mathrm{pN}+$ ) foi detectada no gênero masculino e na raça branca, no entanto, nos espécimes de carcinoma verrucoso (CV) 60\% eram do sexo feminino (TABELA 8).

As amostras positivas para a hipermetilação da E-caderina, no grupo CV, predominaram nos pacientes com idade superior a 59 anos. No grupo de pacientes com carcinomas espinocelulares (CEC-pN0 e CEC-pN+), a presença da hipermetilação da Ecaderina prevaleceu nas idades inferiores ou iguais a 59 anos e destes, $58 \%$ dos pacientes não apresentavam comprometimento linfonodal e 90\% possuíam linfonodos comprometidos pela neoplasia, confirmados microscopicamente (TABELA 8).

O tabagismo e o etilismo foram fatores de riscos constantemente observados nos carcinomas analisados. Das amostras com hipermetilação do gene da E-caderina, 60, 58 e $80 \%$ eram de pacientes tabagistas nos grupos CV, CEC-pN0 e CEC-pN+, respectivamente (Tabela 8).

A hipermetilação da E-caderina e o etilismo estiveram associados em $80 \%$ dos pacientes dos grupos CV e CEC-pN+ e em 50\% do grupo CEC-pN0 como pode ser observado na Tabela 8 .

A maioria dos carcinomas espinocelulares de boca obtida de pacientes tabagistas e que eram também etilistas apresentava hipermetilação do gene da E-caderina. 
TABELA 8 - Distribuição de frequência da hipermetilação do gene da E-caderina segundo às características clínicas dos três grupos de carcinomas de boca. Hospital do Câncer, São Paulo, 1980 a 2000

\begin{tabular}{|c|c|c|c|c|c|c|}
\hline \multirow{4}{*}{ Variável } & \multicolumn{6}{|c|}{ E-caderina-hipermetilação } \\
\hline & \multicolumn{2}{|c|}{$\mathbf{C V}$} & \multicolumn{2}{|c|}{ CEC-pNo } & \multicolumn{2}{|c|}{ CEC-pN+ } \\
\hline & + & - & + & - & + & - \\
\hline & № $(\%)$ & № $(\%)$ & № $(\%)$ & № $(\%)$ & № $(\%)$ & № (\%) \\
\hline \multicolumn{7}{|l|}{ Gênero } \\
\hline Masculino & $2(40)$ & $4(100)$ & $7(58)$ & $4(50)$ & $7(70)$ & $5(71)$ \\
\hline Feminino & $3(60)$ & $0(0)$ & $5(42)$ & $4(50)$ & $3(30)$ & $2(29)$ \\
\hline \multicolumn{7}{|l|}{ Raça } \\
\hline Branca & $4(80)$ & $4(100)$ & $11(92)$ & $7(87,5)$ & $7(70)$ & $6(86)$ \\
\hline Não Branca & $1(20)$ & $0(0)$ & $1(8)$ & $1(12,5)$ & $3(30)$ & $1(14)$ \\
\hline \multicolumn{7}{|l|}{ Idade } \\
\hline$\leq 59$ anos & $2(40)$ & $1(25)$ & $7(58)$ & $1(12,5)$ & $9(90)$ & $4(57)$ \\
\hline$>59$ anos & $3(60)$ & $3(75)$ & $5(42)$ & $7(87,5)$ & $1(10)$ & $3(43)$ \\
\hline \multicolumn{7}{|l|}{ Tabagismo } \\
\hline Não & $1(20)$ & $1(25)$ & $4(34)$ & $4(50)$ & $2(20)$ & $1(14)$ \\
\hline Sim & $3(60)$ & $3(75)$ & $7(58)$ & $4(50)$ & $8(80)$ & $6(86)$ \\
\hline Desconhecido & $1(20)$ & $0(0)$ & $1(8)$ & $0(0)$ & $0(0)$ & $0(0)$ \\
\hline \multicolumn{7}{|l|}{ Etilismo } \\
\hline Não & $0(0)$ & $0(0)$ & $5(42)$ & $4(50)$ & $2(20)$ & $3(43)$ \\
\hline Sim & $4(80)$ & $4(100)$ & $6(50)$ & $4(50)$ & $8(80)$ & $4(57)$ \\
\hline Desconhecido & $1(20)$ & $0(0)$ & $1(8)$ & $0(0)$ & $0(0)$ & $0(0)$ \\
\hline TOTAL & $5(100)$ & $4(100)$ & $12(100)$ & $8(100)$ & $10(100)$ & 7 (100) \\
\hline
\end{tabular}

CV: Carcinoma Verrucoso, CEC-pN0: Carcinoma Espinocelular Bem Diferenciado sem comprometimento linfonodal, CEC-pN+: Carcinoma Espinocelular Bem Diferenciado com comprometimento linfonodal, +: amostras hipermetiladas, -: amostras não hipermetiladas 
O tamanho das neoplasias analisadas, expresso quanto ao estadiamento clínico $\mathrm{T}$, não mostrou associação com a presença ou não de metilação do gene da E-caderina, pois tanto os carcinomas mais avançados (T3 e T4) quanto os iniciais (T1 e T2) apresentaram esse evento epigenético (Tabela 9).

Todos os carcinomas verrucosos foram diagnosticados clinicamente em estádios iniciais (T1-T2) como pode ser verificado na Tabela 9.

Quanto ao estadiamento clínico N, no grupo CEC-pN+, a porcentagem de espécimes hipermetilados foi semelhante $(50 \%)$ entre os pacientes que clinicamente apresentaram nódulos cervicais palpáveis e os que foram considerados N0 (Tabela 9).

A localização mais freqüente dos CVs que apresentavam hipermetilação do gene da E-caderina foi no lábio inferior (40\%) enquanto que a gengiva inferior (33\%) e o assoalho bucal (70\%) predominaram nos espécimes de CEC bem diferenciados sem e com comprometimento linfonodal, respectivamente.

Clinicamente, $80 \%$ dos CVs com hipermetilação da E-caderina possuíam aspecto ulcerovegetante e nos CECs bem diferenciados sem comprometimento linfonodal $50 \%$ dos tumores apresentavam aspecto ulcerovegetante e 50\% ulceroinfiltrativo.

Nos carcinomas espinocelulares com comprometimento linfonodal, $40 \%$ apresentaram-se clinicamente com o aspecto ulcerovegetante, $50 \%$ ulceroinfiltrativo e $10 \%$ continham tanto áreas ulceradas e infiltrativas quanto vegetantes. 
TABELA 9 - Distribuição de frequência da hipermetilação do gene da E-caderina segundo as características clínicas dos três grupos de carcinomas de boca. Hospital do Câncer, São Paulo, 1980 a 2000

\begin{tabular}{|c|c|c|c|c|c|c|}
\hline \multirow{4}{*}{ Variável } & \multicolumn{6}{|c|}{ E-caderina - hipermetilação } \\
\hline & \multicolumn{2}{|c|}{$\mathbf{C V}$} & \multicolumn{2}{|c|}{ CEC-pNO } & \multicolumn{2}{|c|}{ CEC-pN+ } \\
\hline & + & - & + & - & + & - \\
\hline & № $(\%)$ & № $(\%)$ & № $(\%)$ & № $(\%)$ & № $(\%)$ & № (\%) \\
\hline \multicolumn{7}{|l|}{$\mathbf{T}$} \\
\hline $\mathrm{T} 1-2$ & $5(100)$ & $4(100)$ & $6(50)$ & $4(50)$ & $5(50)$ & $3(43)$ \\
\hline T3-4 & $0(0)$ & $0(0)$ & $6(50)$ & $4(50)$ & $5(50)$ & $4(57)$ \\
\hline \multicolumn{7}{|l|}{$\mathbf{N}$} \\
\hline No & $5(100)$ & $4(100)$ & $12(100)$ & $8(100)$ & $5(50)$ & $1(14)$ \\
\hline $\mathrm{N}+$ & $0(0)$ & $0(0)$ & $0(0)$ & $0(0)$ & $5(50)$ & $6(86)$ \\
\hline \multicolumn{7}{|l|}{ Estadio clínico } \\
\hline I-II & $5(100)$ & $4(100)$ & $6(50)$ & $4(50)$ & $4(40)$ & $1(14)$ \\
\hline III-IV & $0(0)$ & $0(0)$ & $6(50)$ & $4(50)$ & $6(60)$ & $6(86)$ \\
\hline \multicolumn{7}{|l|}{ Localização } \\
\hline Lábio inferior & $2(40)$ & $2(50)$ & $0(0)$ & $0(0)$ & $0(0)$ & $0(0)$ \\
\hline Gengiva inferior & $1(20)$ & $1(25)$ & $4(33)$ & $2(25)$ & $2(20)$ & $3(43)$ \\
\hline Gengiva superior & $0(0)$ & $0(0)$ & $1(8)$ & $1(12,5)$ & $1(10)$ & $0(0)$ \\
\hline Palato mole & $0(0)$ & $1(25)$ & $2(17)$ & $0(0)$ & $0(0)$ & $0(0)$ \\
\hline Palato duro & $1(20)$ & $0(0)$ & $0(0)$ & $3(37,5)$ & $0(0)$ & $0(0)$ \\
\hline Assoalho & $0(0)$ & $0(0)$ & $2(17)$ & $0(0)$ & $7(70)$ & $3(43)$ \\
\hline Mucosa jugal & $1(20)$ & $0(0)$ & $3(25)$ & $2(25)$ & $0(0)$ & $1(14)$ \\
\hline \multicolumn{7}{|l|}{ Tipo de lesão } \\
\hline Ulcerovegetante & $4(80)$ & $3(75)$ & $6(50)$ & $6(75)$ & $4(40)$ & $4(57)$ \\
\hline Ulceroinfiltrativa & $0(0)$ & $0(0)$ & $6(50)$ & $1(12,5)$ & $5(50)$ & $3(43)$ \\
\hline Ambas & $0(0)$ & $0(0)$ & $0(0)$ & $1(12,5)$ & $1(10)$ & $0(0)$ \\
\hline Outro & $1(20)$ & $1(25)$ & $0(0)$ & $0(0)$ & $0(0)$ & $0(0)$ \\
\hline TOTAL & $5(100)$ & $4(100)$ & $12(100)$ & $8(100)$ & $10(100)$ & $7(100)$ \\
\hline
\end{tabular}

CV: Carcinoma Verrucoso, CEC-pN0: Carcinoma Espinocelular Bem Diferenciado sem comprometimento linfonodal, CEC-pN+: Carcinoma Espinocelular Bem Diferenciado com comprometimento linfonodal, +: amostras hipermetiladas, -: amostras não hipermetiladas 
Todos os pacientes incluídos neste estudo foram submetidos à cirurgia como tratamento inicial, de acordo com os critérios de inclusão. A radioterapia pós-operatória complementar foi realizada em $42 \%$ dos pacientes com CEC-pN0 e em $90 \%$ dos pacientes com CEC-pN+ e que mostraram hipermetilação do gene da E-caderina (Tabela 10). No grupo dos CVs, a radioterapia pós-operatória complementar não foi realizada.

Quanto à evolução clínica dos pacientes, a freqüência de recidiva e hipermetilação do gene da E-caderina foi observada principalmente no grupo CEC-pN+ $(60 \%$ dos pacientes $)$ quando comparado aos grupos CEC-pN0 (17\% dos pacientes) e CV (20\% dos pacientes) como pode ser observado na Tabela 10.

O período de seguimento dos pacientes variou de 9,2-218 meses (mediana 74 meses) para o grupo CV, de 8,5-203 meses (mediana 102 meses) para o grupo CEC-pN0 e de 1-234 meses (mediana 60 meses) para o grupo CEC-pN+.

Constatou-se o desenvolvimento de um segundo tumor primário em $25 \%$ dos pacientes do grupo CEC-pN0 (rinofaringe e duas neoplasias de lábio) e em 10\% do grupo CEC-pN+ (supraglote) que apresentavam hipermetilação do gene da E-caderina. Nenhum paciente do grupo CV e com hipermetilação desenvolveu segundo tumor primário (Tabela 10). 
TABELA 10 - Distribuição de frequência da hipermetilação do gene da E-caderinas segundo as características clínicas dos três grupos de carcinomas de boca. Hospital do Câncer, São Paulo, 1980 a 2000

\begin{tabular}{|c|c|c|c|c|c|c|}
\hline \multirow{4}{*}{ Variável } & \multicolumn{6}{|c|}{ E-caderina - hipermetilação } \\
\hline & \multicolumn{2}{|c|}{$\mathbf{C V}$} & \multicolumn{2}{|c|}{ CEC-pNO } & \multicolumn{2}{|c|}{ CEC-pN+ } \\
\hline & + & - & + & - & + & - \\
\hline & № $(\%)$ & № $(\%)$ & № $(\%)$ & № (\%) & № $(\%)$ & № $(\%)$ \\
\hline \multicolumn{7}{|l|}{ Radioterapia } \\
\hline Não & $5(100)$ & $4(100)$ & $7(58)$ & $6(75)$ & $1(10)$ & $3(43)$ \\
\hline Sim & $0(0)$ & $0(0)$ & $5(42)$ & $2(25)$ & $9(90)$ & $4(57)$ \\
\hline \multicolumn{7}{|l|}{ Recidiva } \\
\hline Não & $4(80)$ & $2(50)$ & $10(83)$ & $6(75)$ & $4(40)$ & $5(71)$ \\
\hline Sim & $1(20)$ & $2(50)$ & $2(17)$ & $2(25)$ & $6(60)$ & $2(29)$ \\
\hline \multicolumn{7}{|l|}{ Segundo tumor } \\
\hline Não & $5(100)$ & $3(75)$ & $9(75)$ & $7(87,5)$ & $9(90)$ & $6(86)$ \\
\hline Sim & $0(0)$ & $1(25)$ & $3(25)$ & $1(12,5)$ & $1(10)$ & $1(14)$ \\
\hline TOTAL & $5(100)$ & $4(100)$ & $12(100)$ & $8(100)$ & $10(100)$ & $7(100)$ \\
\hline
\end{tabular}

CV: Carcinoma Verrucoso, CEC-pN0: Carcinoma Espinocelular Bem Diferenciado sem comprometimento linfonodal, CEC-pN+: Carcinoma Espinocelular Bem Diferenciado com comprometimento linfonodal, +: amostras hipermetiladas, -: amostras não hipermetiladas 


\subsection{Análise da expressão imuno-histoquímica da E-caderina nos carcinomas verrucosos e espinocelulares de boca}

A expressão da molécula de adesão epitelial E-caderina, foi detectada na mucosa bucal com padrão de normalidade sobrejacente à neoplasia (Figura 8) e na membrana plasmática das células tumorais. Nas amostras de hiperplasias fibrosas inflamatórias (HFs), utilizadas como controle, a expressão desta molécula foi semelhante a da mucosa bucal com padrão de normalidade sobrejacente à neoplasia.

A média da expressão imuno-histoquímica da E-caderina (marcação membranosa completa) foi maior no grupo de carcinomas verrucosos $(70,83+/-22,92)$ quando comparado aos grupos de carcinomas espinocelulares bem diferenciados, sendo os valores estatisticamente significativos $(\mathrm{p}=0,003)$. Nos grupos dos CECs a média foi de $38,26+/-$ 20,10 para os espécimes sem comprometimento linfonodal e de 26,91+/- 15,96 para aqueles com comprometimento linfonodal como pode ser verificado na Tabela 11.

TABELA 11 - Distribuição da expressão imuno-histoquímica do anticorpo E-caderina nos carcinomas verrucosos e carcinomas espinocelulares bem diferenciados de boca. Hospital do Câncer, São Paulo, 1980 a 2000

\begin{tabular}{|c|c|c|c|c|}
\hline \multirow{2}{*}{$\begin{array}{c}\text { E-caderina } \\
\text { (MBC) }\end{array}$} & \multicolumn{3}{|c|}{ Grupo } & \multirow{2}{*}{$p^{*}$} \\
\hline & $\mathrm{CV}$ & CEC-pNo & CEC-pN+ & \\
\hline Mediana & 82,2 & 37,85 & 26,9 & \\
\hline Média & 70,83 & 38,26 & 26,91 & $\mathbf{0 , 0 0 3}$ \\
\hline Desvio Padrão & 22,92 & 20,10 & 15,96 & \\
\hline
\end{tabular}

CV: Carcinoma Verrucoso, CEC-pN0: Carcinoma Espinocelular Bem Diferenciado sem comprometimento linfonodal, CEC-pN+: Carcinoma Espinocelular Bem Diferenciado com comprometimento linfonodal, MBC: Marcação Membranosa Completa

$p^{*}$ : valor obtido pelo teste não paramétrico de Kruskal-Wallis considerando-se nível de significância de 5\% 
A partir dos valores obtidos pela marcação do anticorpo da E-caderina nos três grupos analisados (CV, CEC-pN0 e CEC-pN+), foi determinada a mediana dos valores percentuais obtidos de marcação membranosa completa (MBC) e os resultados foram dicotomizados.

Uma marcação membranosa completa com valor maior que $36,5 \%$ da E-caderina foi predominantemente observada no grupo de CV (89\%) (Figuras 8 e 9) quando comparado ao grupo de CEC-pN0 (50\%) e CECpN+ (29\%), sendo estas diferenças estatisticamente significativas $(\mathrm{p}=0,016)$.

No grupo de CEC-pN0, uma distribuição eqüitativa da expressão da E-caderina foi detectada como pode ser observado na Tabela 12.

A maioria $(71 \%)$ dos carcinomas espinocelulares bem diferenciados com comprometimento linfonodal $(\mathrm{CEC}-\mathrm{pN}+)$, apresentou expressão imuno-histoquímica da Ecaderina com valor inferior ou igual a 36,5\% de MBC (Tabela 12 e Figura 9).

TABELA 12 - Distribuição da expressão imuno-histoquímica do anticorpo E-caderina nos carcinomas verrucosos e carcinomas espinocelulares bem diferenciados de boca. Hospital do Câncer, São Paulo, 1980 a 2000

\begin{tabular}{|c|c|c|c|c|c|c|c|}
\hline \multirow{3}{*}{ Variável } & \multicolumn{6}{|c|}{ GRUPO } & \multirow{3}{*}{$p^{*}$} \\
\hline & \multicolumn{2}{|c|}{$\mathrm{CV}$} & \multicolumn{2}{|c|}{ CEC-pNo } & \multicolumn{2}{|c|}{ CEC-pN+ } & \\
\hline & № & $\%$ & № & $\%$ & № & $\%$ & \\
\hline \multicolumn{8}{|l|}{ E-caderina } \\
\hline$\leq 36,5 \% \mathrm{MBC}$ & 1 & 11 & 10 & 50 & 12 & 71 & 0,016 \\
\hline$>36,5 \% \mathrm{MBC}$ & 8 & 89 & 10 & 50 & 5 & 29 & \\
\hline TOTAL & 9 & 100 & 20 & 100 & 17 & 100 & \\
\hline
\end{tabular}

CV: Carcinoma Verrucoso, CEC-pN0: Carcinoma Espinocelular Bem Diferenciado sem comprometimento linfonodal, CEC-pN+: Carcinoma Espinocelular Bem Diferenciado com comprometimento linfonodal, MBC: Marcação Membranosa Completa $p^{*}$ : valor obtido pelo teste do qui-quadrado considerando-se nível de significância de 5\% 

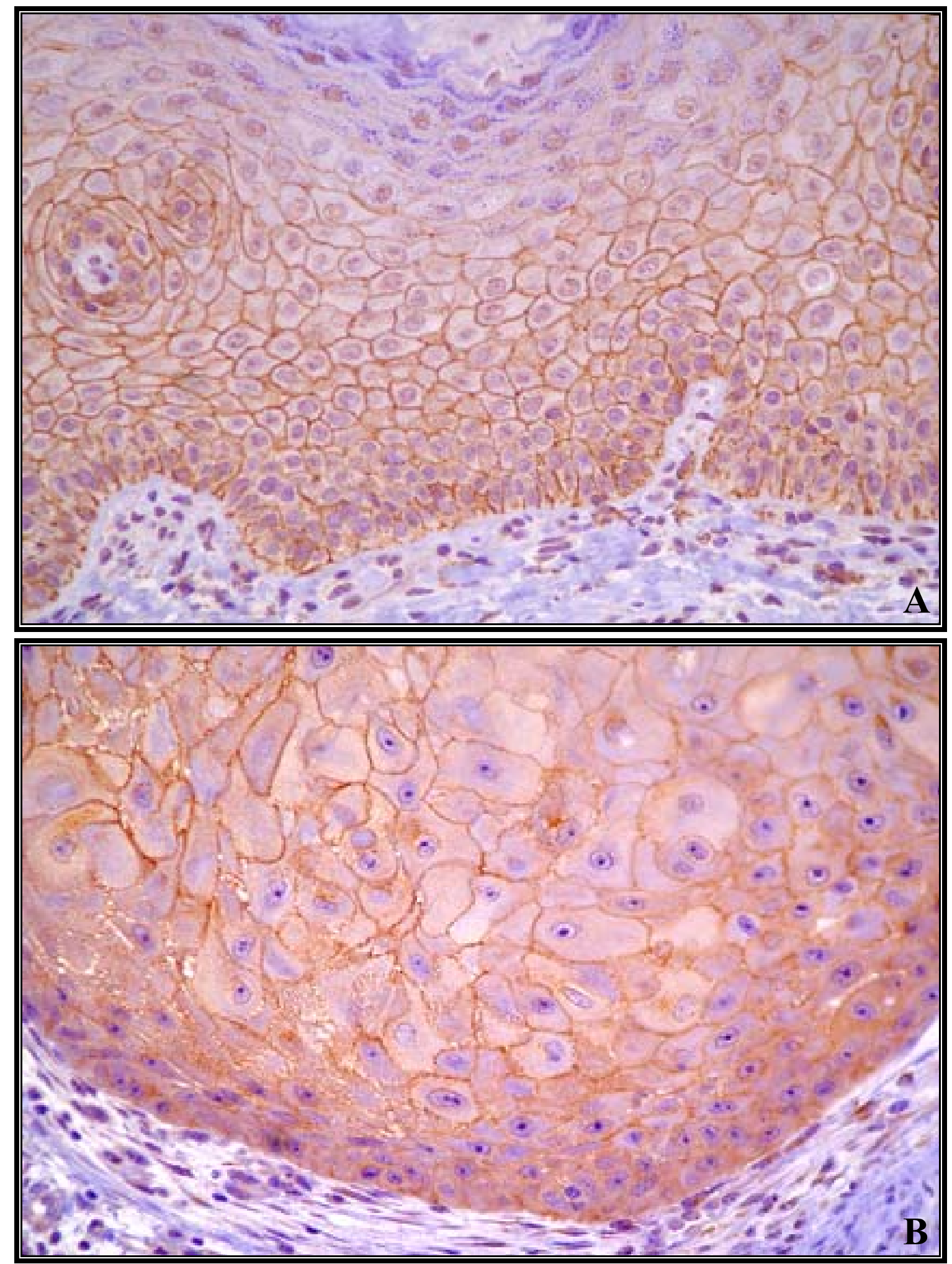

FIGURA 8 - Imunopositividade à E-caderina na mucosa bucal normal (A). Em B, expressão membranosa completa da E-caderina no $\mathrm{CV}$ bucal. (IMH, aumento original $\mathrm{A}$ e $\mathrm{B}=400 \mathrm{X}$ ) 

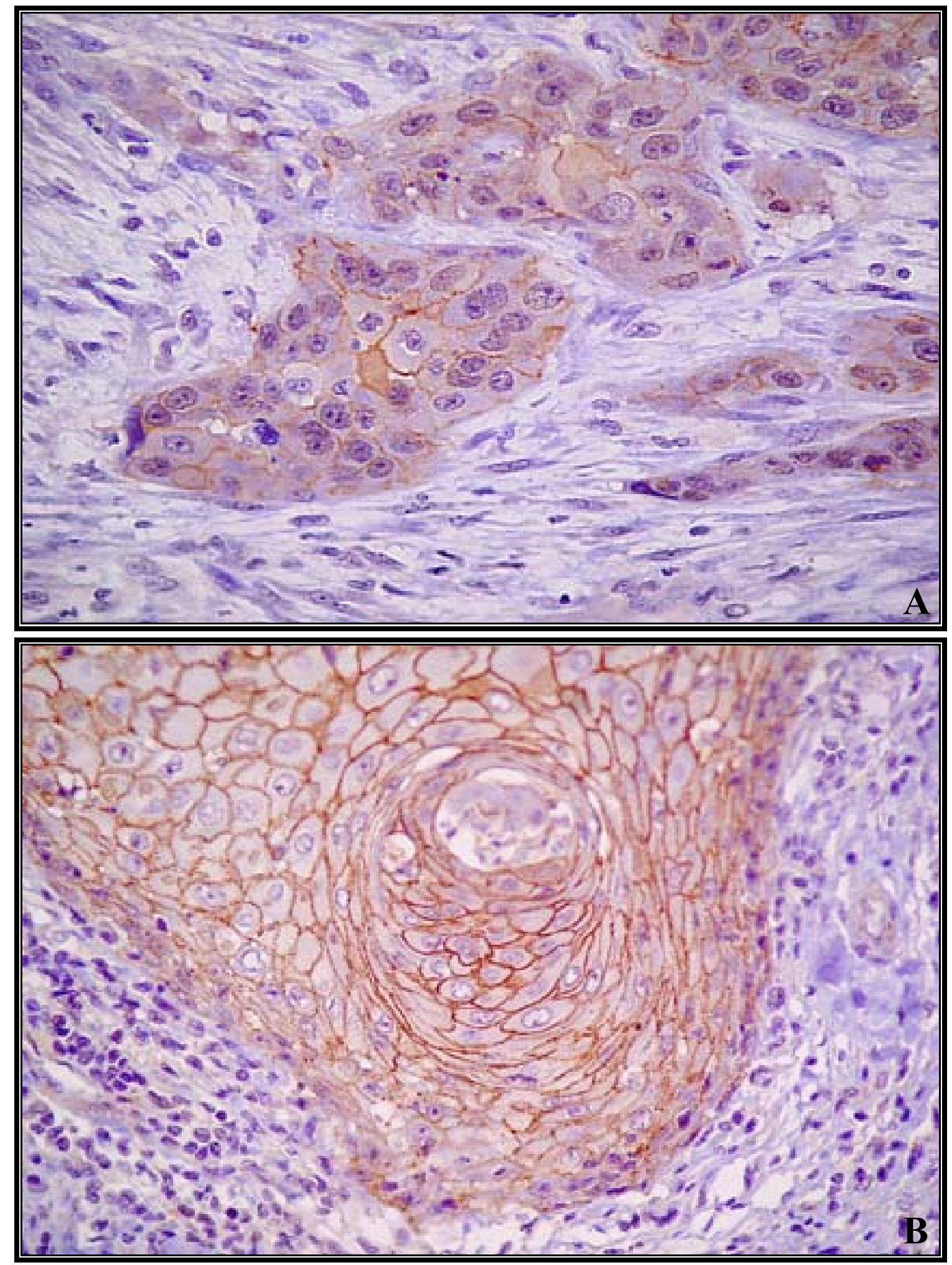

FIGURA 9 - Redução da expressão membranosa completa da E-caderina nas ilhotas epiteliais do CEC bem diferenciado (A). Em B, observa-se no CV bucal a forte expressão na crista epitelial e uma redução desta expressão na região da camada basal do epitélio (B). (IMH, aumento original A e $B=400 X)$ 
A distribuição da expressão do anticorpo E-caderina em relação aos aspectos clínicos, em cada grupo de carcinoma bucal avaliado pode ser observada nas Tabelas 13, 14 e 15.

Uma maior expressão da E-caderina, com valores superiores a 36,5\% de marcação membranosa completa, foi detectada no gênero masculino e na raça branca do grupo de carcinomas verrucosos. Nos grupos dos CECs (CEC-pN0 e CEC-pN+) a predominância no gênero masculino e na raça branca foi da expressão de E-caderina com valores inferiores ou iguais a $36,5 \% \mathrm{MBC}$ (Tabela 13$)$.

Os pacientes com idade superior a 59 anos apresentaram maior percentual de MBC para a E-caderina nos grupos de carcinomas verrucoso e carcinomas espinocelulares sem comprometimento linfonodal (Tabela 13). Entretanto, no grupo CEC-pN+, a grande maioria dos pacientes com idade inferior ou igual a 59 anos no momento do diagnóstico clínico, apresentou expressão de E-caderina com valor inferior ou igual a 36,5\% MBC.

Nos CVs com expressão de E-caderina superior a 36,5\% MBC, $75 \%$ eram de pacientes tabagistas e 100\% de etilistas. Quanto aos CECs com valores inferiores ou iguais a $36,5 \%$ MBC para E-caderina, a freqüência de tabagismo e etilismo foi de 60 e $30 \%$ para os pacientes sem comprometimento linfonodal e 83 e 67\% naqueles com comprometimento linfonodal, respectivamente (Tabela 13).

A maioria dos pacientes com carcinoma espinocelular e comprometimento linfonodal $(\mathrm{CEC}-\mathrm{pN}+)$ que eram etilistas e tabagistas concomitantemente apresentou $\mathrm{MBC}$ inferior ou igual a 36,5\%. Nos grupos de carcinomas verrucosos e carcinomas espinocelulares sem comprometimento linfonodal ( $\mathrm{CV}$ e CEC-pN0), os pacientes tabagistas e etilistas possuíam MBC superior a 36,5\%. 
TABELA 13 - Distribuição de frequência da expressão imuno-histoquímica da E-caderina segundo as características clínicas dos três grupos de carcinomas de boca. Hospital do Câncer, São Paulo, 1980 a 2000

\begin{tabular}{|c|c|c|c|c|c|c|}
\hline \multirow{4}{*}{ Variável } & \multicolumn{6}{|c|}{ E-caderina - Marcação membranosa completa } \\
\hline & \multicolumn{2}{|c|}{$\mathbf{C V}$} & \multicolumn{2}{|c|}{ CEC-pNo } & \multicolumn{2}{|c|}{ CEC-pN+ } \\
\hline & $\leq 36,5$ & $>36,5$ & $\leq 36,5$ & $>36,5$ & $\leq 36,5$ & $>36,5$ \\
\hline & № (\%) & № $(\%)$ & № $(\%)$ & № $(\%)$ & № (\%) & № (\%) \\
\hline \multicolumn{7}{|l|}{ Gênero } \\
\hline Masculino & $0(0)$ & $6(75)$ & $6(60)$ & $5(50)$ & $9(75)$ & $3(60)$ \\
\hline Feminino & $1(100)$ & $2(25)$ & $4(40)$ & $5(50)$ & $3(25)$ & $2(40)$ \\
\hline \multicolumn{7}{|l|}{ Raça } \\
\hline Branca & $1(100)$ & $7(87,5)$ & $10(100)$ & $8(80)$ & $9(75)$ & $4(80)$ \\
\hline Não Branca & $0(0)$ & $1(12,5)$ & $0(0)$ & $2(20)$ & $3(25)$ & $1(20)$ \\
\hline \multicolumn{7}{|l|}{ Idade } \\
\hline$\leq 59$ anos & $1(100)$ & $2(25)$ & $7(70)$ & $1(10)$ & $9(75)$ & $4(80)$ \\
\hline$>59$ anos & $0(0)$ & $6(75)$ & $3(30)$ & $9(90)$ & $3(25)$ & $1(20)$ \\
\hline \multicolumn{7}{|l|}{ Tabagismo } \\
\hline Não & $0(0)$ & $2(25)$ & $3(30)$ & $5(50)$ & $2(17)$ & $1(20)$ \\
\hline $\operatorname{Sim}$ & $0(0)$ & $6(75)$ & $6(60)$ & $5(50)$ & $10(83)$ & $4(80)$ \\
\hline Desconhecido & $1(100)$ & $0(0)$ & $1(10)$ & $0(0)$ & $0(0)$ & $0(0)$ \\
\hline \multicolumn{7}{|l|}{ Etilismo } \\
\hline Não & $0(0)$ & $0(0)$ & $6(60)$ & $3(30)$ & $4(33)$ & $1(20)$ \\
\hline Sim & $0(0)$ & $8(100)$ & $3(30)$ & $7(70)$ & $8(67)$ & $4(80)$ \\
\hline Desconhecido & $1(100)$ & $0(0)$ & $1(10)$ & $0(0)$ & $0(0)$ & $0(0)$ \\
\hline TOTAL & $1(100)$ & 8 (100) & $10(100)$ & $10(100)$ & $12(100)$ & $5(100)$ \\
\hline
\end{tabular}

CV: Carcinoma Verrucoso, CEC-pN0: Carcinoma Espinocelular Bem Diferenciado sem comprometimento linfonodal, CEC-pN+: Carcinoma Espinocelular Bem Diferenciado com comprometimento linfonodal 
Quanto ao estádio clínico no grupo CEC-pN0 houve uma distribuição equitativa da expressão imuno-histoquímica da E-caderina sendo que 50\% dos pacientes apresentaram estádios iniciais (I e II) e 50\% estádios avançados (III e IV) como pode ser verificado na Tabela 14.

A grande maioria dos pacientes com carcinoma espinocelular e comprometimento linfonodal (CEC-pN+) em estadios avançados (III e IV) apresentou expressão de E-caderina com valor inferior ou igual a 36,5\% MBC. Todos CVs foram diagnosticados em estádios iniciais (I e II) e a maioria apresentou expressão de E-caderina com valor superior a 36,5\% MBC (Tabela 14).

Uma predominância de lesões de carcinoma verrucoso localizadas no lábio inferior e com aspecto clínico ulcerovegetante apresentava expressão de E-caderina com valor superior a 36,5\% MBC. Para os grupos de CECs (CEC-pN0 e CEC-pN+), valores inferiores ou iguais a 36,5\% MBC prevaleceram nas lesões de gengiva inferior e mucosa jugal nos pacientes sem comprometimento linfonodal e no assoalho de boca seguido pela gengiva inferior naqueles com comprometimento linfonodal. Outros detalhes da distribuição imuno-histoquímica da Ecaderina em relação a localização das lesões pode ser verificado na Tabela 14.

No grupo CEC-pN0, em relação ao aspecto clínico da lesão, o aspecto ulcerovegetante foi mais freqüentemente observado nos carcinomas com expressão de Ecaderina com valor superior a $36,5 \%$. Por outro lado, no grupo de carcinomas espinocelulares com comprometimento linfonodal (CEC-pN+) as lesões com aspecto ulceroinfiltrativo (50\%) e ulcerovegetante (42\%) apresentavam expressão de E-caderina com valores inferiores ou iguais a $36,5 \% \mathrm{MBC}$ (Tabela 14). 
TABELA 14 - Distribuição de frequência da expressão imuno-histoquímica da E-caderina segundo as características clínicas dos três grupos de carcinomas de boca. Hospital do Câncer, São Paulo, 1980 a 2000

\begin{tabular}{|c|c|c|c|c|c|c|}
\hline \multirow{4}{*}{ Variável } & \multicolumn{6}{|c|}{ E-caderina - Marcação membranosa completa } \\
\hline & \multicolumn{2}{|c|}{$\mathbf{C V}$} & \multicolumn{2}{|c|}{ CEC-pNO } & \multicolumn{2}{|c|}{ CEC-pN+ } \\
\hline & $\leq 36,5$ & $>\mathbf{3 6 , 5}$ & $\leq \mathbf{3 6 , 5}$ & $>\mathbf{3 6 , 5}$ & $\leq \mathbf{3 6 , 5}$ & $>36,5$ \\
\hline & № (\%) & № $(\%)$ & № (\%) & № (\%) & № (\%) & № (\%) \\
\hline \multicolumn{7}{|l|}{$\mathbf{T}$} \\
\hline $\mathrm{T} 1-2$ & $1(100)$ & $8(100)$ & $5(50)$ & $5(50)$ & $6(50)$ & $2(40)$ \\
\hline T3-4 & $0(0)$ & $0(0)$ & $5(50)$ & $5(50)$ & $6(50)$ & $3(60)$ \\
\hline \multicolumn{7}{|l|}{$\mathbf{N}$} \\
\hline No & $1(100)$ & $8(100)$ & $10(100)$ & $10(100)$ & $3(25)$ & $3(60)$ \\
\hline $\mathrm{N}+$ & $0(0)$ & $0(0)$ & $0(0)$ & $0(0)$ & $9(75)$ & $2(40)$ \\
\hline \multicolumn{7}{|l|}{ Estadio clínico } \\
\hline I-II & $1(100)$ & $8(100)$ & $5(50)$ & $5(50)$ & $3(25)$ & $2(40)$ \\
\hline III-IV & $0(0)$ & $0(0)$ & $5(50)$ & $5(50)$ & $9(75)$ & $3(60)$ \\
\hline \multicolumn{7}{|l|}{ Localização } \\
\hline Lábio inferior & $0(0)$ & $4(50)$ & $0(0)$ & $0(0)$ & $0(0)$ & $0(0)$ \\
\hline Gengiva inferior & $0(0)$ & $2(25)$ & $3(30)$ & $3(30)$ & $4(34)$ & $1(20)$ \\
\hline Gengiva superior & $0(0)$ & $0(0)$ & $1(10)$ & $1(10)$ & $1(8)$ & $0(0)$ \\
\hline Palato mole & $0(0)$ & $1(12,5)$ & $2(20)$ & $0(0)$ & $0(0)$ & $0(0)$ \\
\hline Palato duro & $1(100)$ & $0(0)$ & $0(0)$ & $3(30)$ & $0(0)$ & $0(0)$ \\
\hline Assoalho & $0(0)$ & $0(0)$ & $1(10)$ & $1(10)$ & $6(50)$ & $4(80)$ \\
\hline Mucosa jugal & $0(0)$ & $1(12,5)$ & $3(30)$ & $2(20)$ & $1(8)$ & $0(0)$ \\
\hline \multicolumn{7}{|l|}{ Tipo de lesão } \\
\hline Ulcerovegetante & $1(100)$ & $6(75)$ & $5(50)$ & $7(70)$ & $6(50)$ & $2(40)$ \\
\hline Ulceroinfiltrativa & $0(0)$ & $0(0)$ & $5(50)$ & $2(20)$ & $5(42)$ & $3(60)$ \\
\hline Ambas & $0(0)$ & $0(0)$ & $0(0)$ & $1(10)$ & $1(8)$ & $0(0)$ \\
\hline Outro & $0(0)$ & $2(25)$ & $0(0)$ & $0(0)$ & $0(0)$ & $0(0)$ \\
\hline TOTAL & $1(100)$ & $8(100)$ & $10(100)$ & $10(100)$ & $12(100)$ & $5(100)$ \\
\hline
\end{tabular}

CV: Carcinoma Verrucoso, CEC-pN0: Carcinoma Espinocelular Bem Diferenciado sem comprometimento linfonodal, CEC-pN+: Carcinoma Espinocelular Bem Diferenciado com comprometimento linfonodal 
A radioterapia pós-operatória complementar foi realizada em sete dos 20 pacientes com CEC-pN0 e destes a expressão de E-caderina foi maior que 36,5\% $\mathrm{MBC}$ em quatro pacientes e menor ou igual a $36,5 \%$ em três pacientes. A maioria dos pacientes com CEC-pN+ foi submetida à radioterapia pós-operatória e apresentou expressão de E-caderina com valor de $\mathrm{MBC}$ inferiores ou iguais a 36,5\%. No grupo dos CVs, a radioterapia pós-operatória complementar não foi realizada (Tabela 15).

Quanto à evolução clínica, 25\% dos pacientes com carcinomas verrucosos $(\mathrm{CV})$ e com MBC superior a 36,5\% apresentaram recidivas (Tabela 15). No grupo CEC-pN0, as recidivas ocorreram em apenas quatro dos 20 pacientes avaliados e a expressão de E-caderina foi distribuída igualmente entre as variáveis adotadas para a imunomarcação. Nos carcinomas bem diferenciados com comprometimento linfonodal $(\mathrm{CEC}-\mathrm{pN}+)$, a recidiva ocorreu em oito dos 17 pacientes e houve uma predominância da expressão de E-caderina com valor inferior ou igual a $36,5 \%$ MBC neste grupo (Tabela 15$)$.

O desenvolvimento de um segundo tumor primário ocorreu em apenas um paciente do grupo $\mathrm{CV}$, em quatro pacientes do grupo CEC-pN0 e em dois pacientes do grupo CECpN+ (Tabela 15). A maioria dos pacientes com carcinoma verrucoso e CEC-pN0 e ausência de um segundo tumor primário apresentou expressão imuno-histoquímica de E-caderina com valor maior que 36,5\% MBC. Para o grupo CEC-pN+ uma predominância de pacientes sem segundo tumor primário e expressão imuno-histoquímica com valor menor ou igual a 36,5\% foi detectada como pode ser observado na Tabela 15 . 
TABELA 15 - Distribuição de frequência da expressão imuno-histoquímica da E-caderina segundo as características clínicas dos três grupos de carcinomas de boca. Hospital do Câncer, São Paulo, 1980 a 2000

\begin{tabular}{|c|c|c|c|c|c|c|}
\hline \multirow{4}{*}{ Variável } & \multicolumn{6}{|c|}{ E-caderina - Marcação membranosa completa } \\
\hline & \multicolumn{2}{|c|}{$\mathbf{C V}$} & \multicolumn{2}{|c|}{ CEC-pNO } & \multicolumn{2}{|c|}{ CEC-pN+ } \\
\hline & $\leq 36,5$ & $>\mathbf{3 6 , 5}$ & $\leq 36,5$ & $>\mathbf{3 6 , 5}$ & $\leq 36,5$ & $>36,5$ \\
\hline & № (\%) & № (\%) & № (\%) & № (\%) & № (\%) & № $(\%)$ \\
\hline \multicolumn{7}{|l|}{ Radioterapia } \\
\hline Não & $1(100)$ & $8(100)$ & $7(70)$ & $6(60)$ & $3(25)$ & $1(20)$ \\
\hline $\operatorname{Sim}$ & $0(0)$ & $0(0)$ & $3(30)$ & $4(40)$ & $9(75)$ & $4(80)$ \\
\hline \multicolumn{7}{|l|}{ Recidiva } \\
\hline Não & $0(0)$ & $6(75)$ & $8(80)$ & $8(80)$ & $7(58)$ & $2(40)$ \\
\hline Sim & $1(100)$ & $2(25)$ & $2(20)$ & $2(20)$ & $5(42)$ & $3(60)$ \\
\hline \multicolumn{7}{|l|}{ Segundo tumor } \\
\hline Não & $1(100)$ & $7(87,5)$ & $7(70)$ & $9(90)$ & $10(83)$ & $5(100)$ \\
\hline $\operatorname{Sim}$ & $0(0)$ & $1(12,5)$ & $3(30)$ & $1(10)$ & $2(17)$ & $0(0)$ \\
\hline TOTAL & $1(100)$ & $8(100)$ & $10(100)$ & $10(100)$ & $12(100)$ & $5(100)$ \\
\hline
\end{tabular}




\subsection{Correlação da expressão imuno-histoquímica e a hipermetilação do gene da E-caderina nos carcinomas bucais}

Nenhuma correlação estatisticamente significativa foi obtida entre a expressão imuno-histoquímica e a hipermetilação do gene da E-caderina para os carcinomas verrucosos e carcinomas espinocelulares sem comprometimento linfonodal (Tabela 16).

Entretanto para o grupo de CEC-pN+, um aspecto interessante observado foi que todos os espécimes que não apresentavam hipermetilação da E-caderina demonstraram expressão imuno-histoquímica inferior ou igual a 36,5\% $\mathrm{MBC}$, sendo esta correlação estatisticamente significativa $(\mathrm{p}=0,044)$ como pode ser verificado na Tabela 16 .

TABELA 16 - Distribuição do perfil de metilação do gene da E-caderina em relação a expressão imuno-histoquímica da E-caderina nos carcinomas verrucosos e carcinomas espinocelulares bem diferenciados de boca. Hospital do Câncer, São Paulo, 1980 a 2000

\begin{tabular}{|c|c|c|c|c|c|c|c|c|c|}
\hline \multirow{3}{*}{$\begin{array}{c}\text { IMH } \\
\text { (MBC) }\end{array}$} & \multicolumn{9}{|c|}{ METILAÇÃO - E-caderina } \\
\hline & \multicolumn{3}{|c|}{$\mathbf{C V}$} & \multicolumn{3}{|c|}{ CEC-pNO } & \multicolumn{3}{|c|}{ CEC-pN+ } \\
\hline & + & - & $p$ & + & - & $p^{* *}$ & + & - & $p^{* *}$ \\
\hline$\leq 36,5 \%$ & 1 & 0 & \multirow{2}{*}{ NA } & 8 & 2 & \multirow{2}{*}{0,170} & 5 & 7 & \multirow{2}{*}{$\mathbf{0 , 0 4 4}$} \\
\hline$>36,5 \%$ & 4 & 4 & & 4 & 6 & & 5 & 0 & \\
\hline TOTAL & 5 & 4 & & 12 & 8 & & 10 & 7 & \\
\hline
\end{tabular}

CV: Carcinoma Verrucoso, CEC-pN0: Carcinoma Espinocelular Bem Diferenciado sem comprometimento linfonodal, CEC-pN+: Carcinoma Espinocelular Bem Diferenciado com comprometimento linfonodal, IMH: Imuno-histoquímica, MBC: Marcação Membranosa Completa, NA: não se aplica, +: amostras metiladas, -: amostras não metiladas $p^{* *}$ : valor obtido pelo teste exato de Fisher considerando-se nível de significância de 5\% 
Quando os grupos de carcinomas bucais analisados foram correlacionados dois a dois, não se observou diferença estatisticamente significativa $(p=0,999)$ quanto ao perfil de hipermetilação do gene da E-caderina (Tabela 17).

A comparação realizada quanto à imuno-histoquímica, mostrou uma diferença estatisticamente significativa entre os carcinomas verrucosos (CVs) e os carcinomas espinocelulares bem diferenciados com comprometimento linfonodal $(p=0,011)$ como pode ser verificado na Tabela 17.

Entre os grupos CV e CEC-pN0, os resultados sugerem que há diferença na expressão imuno-histoquímica da E-caderina, pois o valor obtido de $p$ foi marginal $(p=0,096)$ ao nível de significância empregado $(p<0,05)$. Entre os grupos de CECs $($ CEC-pN0 e CEC$\mathrm{pN}+$ ) a diferença entre a expressão imuno-histoquímica de E-caderina (MBC) não foi estatisticamente significativa $(\mathrm{p}=0,315)$ (Tabela 17).

TABELA 17 - Correlação entre os valores de $p$ e os grupos de carcinomas de boca, agrupados 2x2, quanto à expressão imuno-histoquímica e o perfil de metilação do gene da E-caderina. Hospital do Câncer, São Paulo, 1980 a 2000

\begin{tabular}{c|c|c|c}
\hline \hline \multirow{2}{*}{ E-caderina } & CV x CEC-pN0 & CV x CEC-pN+ & CEC-pN0 x CEC-pN+ \\
\cline { 2 - 4 } & $\boldsymbol{p}^{*}$ & $\boldsymbol{p}^{*}$ & $\boldsymbol{p}^{*}$ \\
\hline \multirow{2}{*}{ IMH (MBC) } & 0,096 & $\mathbf{0 , 0 1 1}$ & 0,315 \\
\hline PM & 0,999 & 0,999 & 0,999 \\
\hline \hline
\end{tabular}

CV: Carcinoma Verrucoso, CEC-pN0: Carcinoma Espinocelular Bem Diferenciado sem comprometimento linfonodal, CEC-pN+: Carcinoma Espinocelular Bem Diferenciado com comprometimento linfonodal, IMH (MBC): Imuno-histoquímica (Marcação Membranosa Completa), PM: perfil de metilação $p^{*}$ : valor obtido pelo teste exato de Fisher considerando-se nível de significância de 5\% 


\subsection{Análise de sobrevida}

O período de seguimento dos pacientes variou de 9,2-218 meses (média 58 meses, desvio padrão 67,7) para o grupo $\mathrm{CV}$, de 8,5-203 meses (média 112 meses, desvio padrão 53,0) para o grupo CEC-pN0 e de 1-234 meses (média 12 meses, desvio padrão, 76,3) para o grupo CEC-pN+.

Ao final deste estudo, em janeiro de 2005, quatro pacientes (40\%) do grupo CV estavam vivos, sem evidências de recidiva da doença, três pacientes $(30 \%)$ morreram por outras causas não relacionadas ao câncer e três pacientes $(30 \%)$ foram considerados perdidos de vista.

No grupo CEC-pN0, dez pacientes (50\%) estavam vivos, sem evidências de doença recorrente, cinco pacientes $(25 \%)$ faleceram em decorrência do tumor primário e cinco $(25 \%)$ morreram por outras causas não relacionadas ao câncer. Dos pacientes pertencentes ao grupo CEC-pN+, dois (11\%) apresentavam-se vivos sem evidências de recidiva da doença, três (18\%) morreram por outras causas não relacionadas ao câncer, 12 (71\%) faleceram em decorrência do tumor primário.

As probabilidades de sobrevida global e sobrevida livre de doença, acumuladas em cinco e dez anos foram calculadas pelo estimador produto-limite de Kaplan-Meier. A comparação entre as curvas de sobrevida global, realizadas através do teste de logrank, apresentou diferença estatisticamente significativa entre os grupos CV, CEC-pN0 e CEC-pN+ $(p=0,012)$ como pode ser verificado na Tabela 18 e Figura 10. A comparação entre as curvas de sobrevida livre de doença dos carcinomas bucais analisados sugere diferença estatística entre os grupos (CV, CEC-pN0 e CEC-pN+) devido ao valor marginal de $p(p=0,076)$, como pode ser observado na Tabela 18 e Figura 11. 
TABELA 18 - Análise de sobrevida global e sobrevida livre de doença dos pacientes com carcinomas verrucosos e espinocelulares de boca

Probabilidade de sobrevida acumulada pela técnica de Kaplan-Meier

\begin{tabular}{lccc|ccc}
\hline \hline & \multicolumn{3}{c|}{ Sobrevida Global } & \multicolumn{3}{c}{ Sobrevida Livre de Doença } \\
Variável & $\mathbf{5} \operatorname{anos}(\%)$ & $\mathbf{1 0} \operatorname{anos}(\%)$ & $\boldsymbol{p}^{*}$ & $\mathbf{5} \operatorname{anos}(\%)$ & $\mathbf{1 0} \operatorname{anos}(\%)$ & $\boldsymbol{p}^{*}$ \\
\hline Grupo & & & & & & \\
CV & 87,5 & 65,6 & $\mathbf{0 , 0 1 2}$ & 65,61 & 52,49 & 0,076 \\
CEC-pN0 & 85,0 & 55,0 & & 84,86 & 84,86 & \\
CEC-pN+ & 35,2 & 29,1 & & 57,78 & 48,15 & \\
\hline \hline
\end{tabular}

$\overline{\mathrm{CV} \text { : Carcinoma Verrucoso, CEC-pN0: Carcinoma Espinocelular Bem Diferenciado sem }}$ comprometimento linfonodal, CEC-pN+: Carcinoma Espinocelular Bem Diferenciado com comprometimento linfonodal.

$p^{*}$ : valor obtido pelo teste de logrank considerando-se nível de significância de 5\%

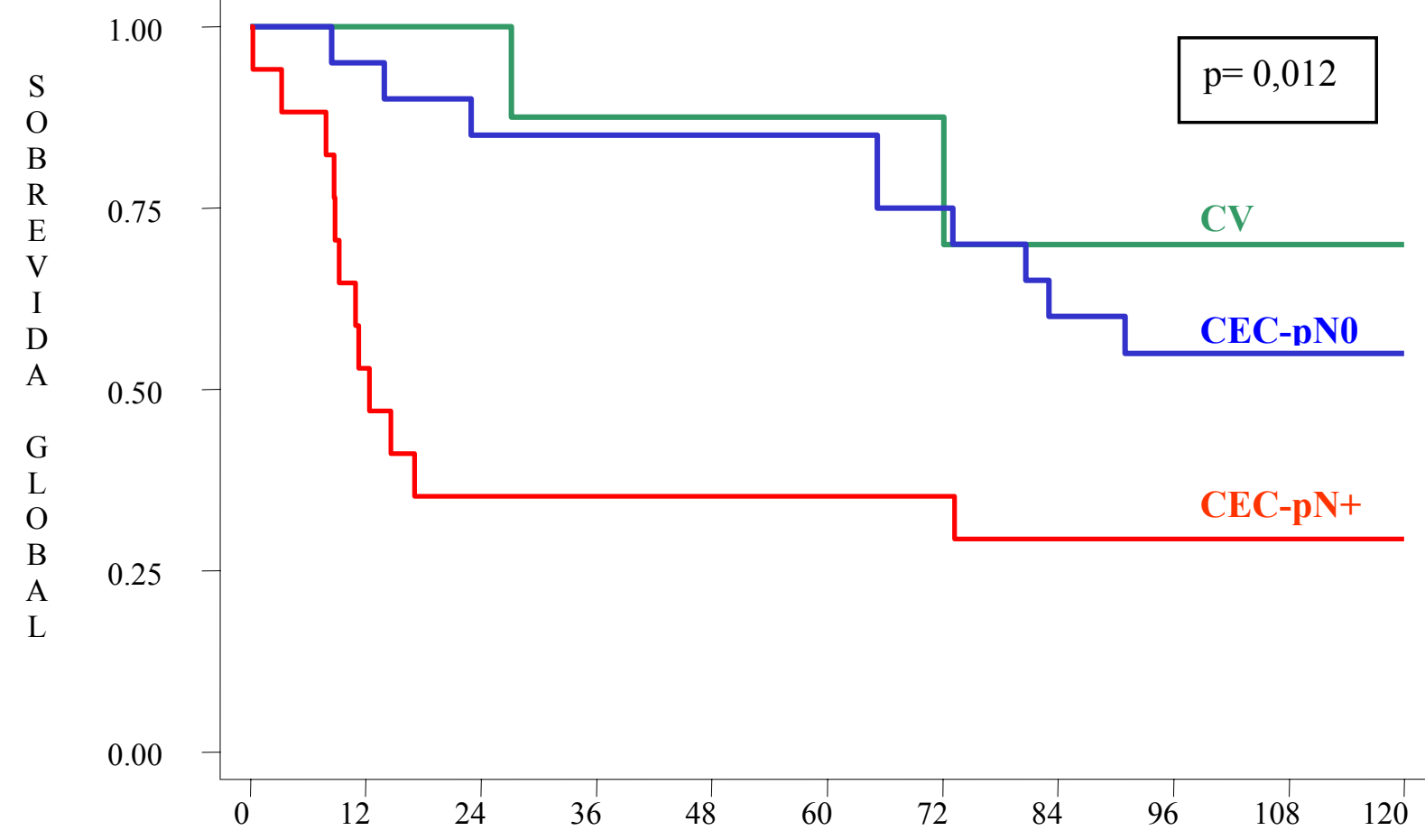

MESES

FIGURA 10 - Sobrevida global dos pacientes com carcinoma verrucoso (CV), carcinomas espinocelulares bem diferenciados sem comprometimento linfonodal (CEC-pN0) e com comprometimento linfonodal (CEC-pN+)

Porcentagem de sobrevida acumulada pela técnica de Kaplan-Meier 


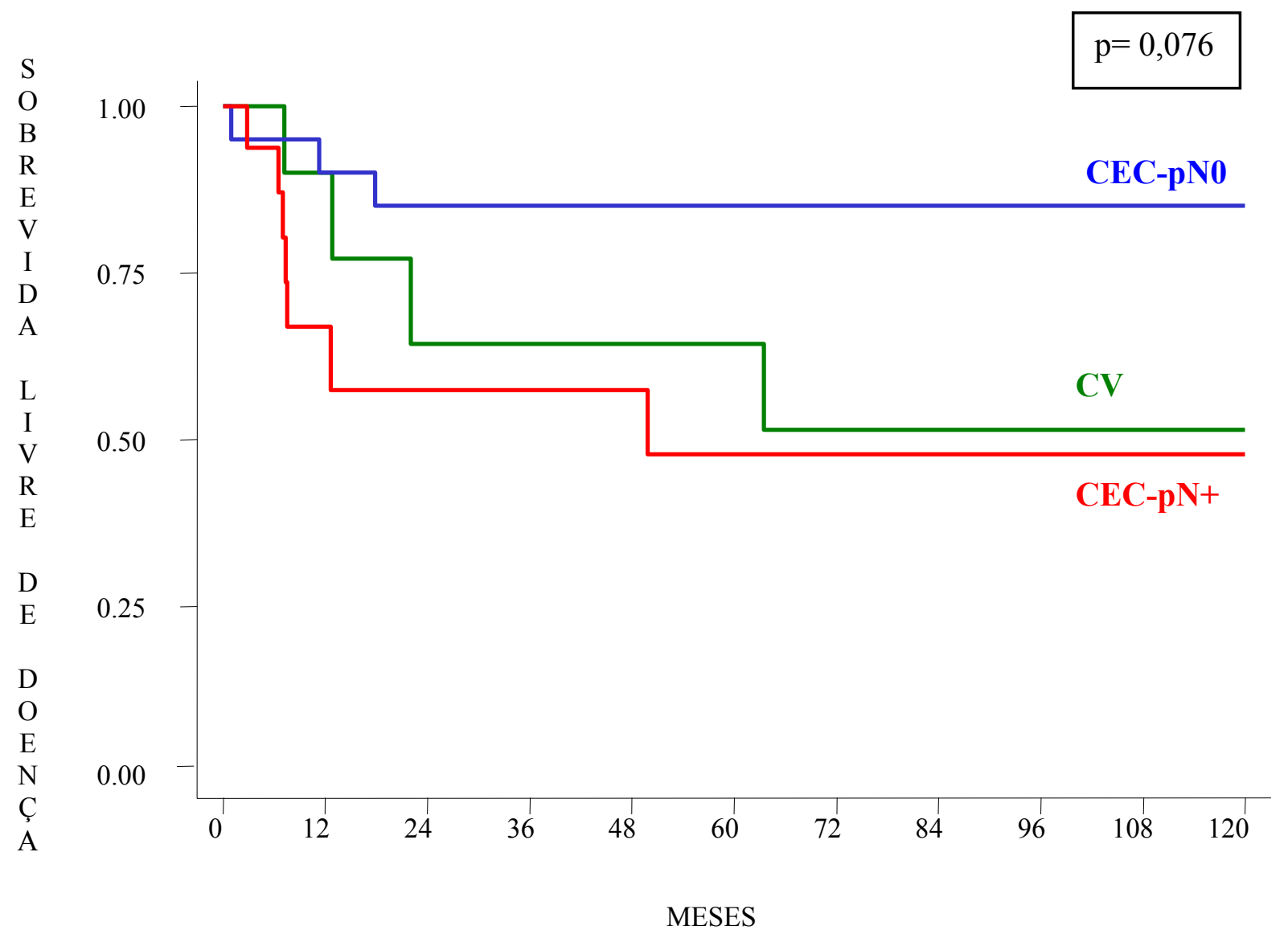

FIGURA 11 - Sobrevida livre de doença dos pacientes com carcinoma verrucoso (CV), carcinomas espinocelulares bem diferenciados sem comprometimento linfonodal (CEC-pN0) e com comprometimento linfonodal (CEC-pN+). Porcentagem de sobrevida acumulada pela técnica de Kaplan-Meier

A probabilidade de sobrevida global nos diferentes grupos de carcinomas bucais analisados em relação à marcação do anticorpo da E-caderina sugere a existência de uma diferença entre os espécimes com valor de MBC inferior ou igual a 36,5\% em razão do valor marginal de $p(\mathrm{p}=0,066)$. Nos carcinomas bucais com expressão de E-caderina superior a $36,5 \%$ MBC não se detectou diferença significativa $(p=0,184)$ na sobrevida global $(5$ e 10 anos) como pode ser verificado na Tabela 19.

A correlação da presença ou não da hipermetilação do gene da E-caderina e a probabilidade de sobrevida global nos grupos de carcinomas bucais estudados (Tabela 19) demonstrou uma maior sobrevida para os pacientes do grupo $\mathrm{CV}$, seguidos pelos pacientes do 
grupo CEC-pN0 e CEC-pN+, sendo a diferença entre os grupos estatisticamente significativa para as amostras que não apresentavam hipermetilação do gene da E-caderina $(p=0,031)$. Para as amostras hipermetiladas, o valor de $p$ foi marginal $(\mathrm{p}=0,072)$, sugerindo uma diferença entre os grupos.

TABELA 19 - Análise de sobrevida global dos três grupos de carcinomas de boca em relação a imuno-histoquímica e o perfil de metilação do gene da E-caderina Probabilidade de sobrevida acumulada pela técnica de Kaplan-Meier

\begin{tabular}{|c|c|c|c|c|c|}
\hline \multirow[t]{2}{*}{ E-caderina } & & \multicolumn{2}{|c|}{ Sobrevida Global } & \multirow[b]{2}{*}{ CEC-pN+ } & \multirow[b]{2}{*}{$p^{*}$} \\
\hline & & $\mathrm{CV}$ & CEC-pNO & & \\
\hline \multicolumn{6}{|l|}{ IMH (MBC) } \\
\hline \multirow{2}{*}{$\leq 36,5 \%$} & $5 \operatorname{anos}(\%)$ & 100 & 90 & 42 & \multirow{2}{*}{0,066} \\
\hline & $10 \operatorname{anos}(\%)$ & 100 & 60 & 33 & \\
\hline \multirow{2}{*}{$>36,5 \%$} & $5 \operatorname{anos}(\%)$ & 100 & 80 & 20 & \multirow{2}{*}{0,184} \\
\hline & $10 \operatorname{anos}(\%)$ & 67 & 50 & 20 & \\
\hline \multicolumn{6}{|l|}{ Metilação } \\
\hline \multirow{2}{*}{ Metilado } & $5 \operatorname{anos}(\%)$ & 100 & 83 & 30 & \multirow{2}{*}{0,072} \\
\hline & $10 \operatorname{anos}(\%)$ & 60 & 42 & 20 & \\
\hline \multirow{2}{*}{ Não metilado } & $5 \operatorname{anos}(\%)$ & 100 & 87,5 & 43 & \multirow{2}{*}{$\mathbf{0 , 0 3 1}$} \\
\hline & $10 \operatorname{anos}(\%)$ & 100 & 75 & 43 & \\
\hline
\end{tabular}

$\overline{\mathrm{CV} \text { : Carcinoma Verrucoso, CEC-pN0: Carcinoma Espinocelular Bem Diferenciado sem }}$ comprometimento linfonodal, CEC-pN+: Carcinoma Espinocelular Bem Diferenciado com comprometimento linfonodal, IMH: Imuno-histoquímica, MBC: Marcação Membranosa Completa

$p^{*}$ : valor obtido pelo teste de lorank considerando-se nível de significância de 5\%

A probabilidade de sobrevida livre de doença nos grupos de carcinomas quanto à imunomarcação da E-caderina, mostrou-se estatisticamente significativa tanto para os valores superiores a $36,5 \% \mathrm{MBC}(\mathrm{p}=0,040)$ quanto para aqueles inferiores ou iguais a $36,5 \% \mathrm{MBC}$ $(p=0,036)$. Para os pacientes dos grupos CV e CEC-pN0, as sobrevidas livres de doença em 
cinco e dez anos foram próximas porém, percentualmente, bem maiores quando comparadas àquelas do grupo CEC-pN+ (Tabela 20).

Em relação a hipermetilação do gene da E-caderina, a sobrevida livre de doença em cinco e dez anos foi semelhante para os grupos CV e CEC-pN0 e apresentou menores valores para o grupo CEC-pN+ sendo a diferença estatística marginal entre os grupos de carcinomas metilados $(p=0,062)$ como pode ser observado na Tabela 20. No grupo de carcinomas com ausência de metilação do gene da E-caderina, não houve diferença estatística $(p=0,611)$ entre as sobrevidas livres de doença dos três grupos de carcinomas bucais analisados (Tabela 20).

TABELA 20 - Análise de sobrevida livre de doença dos três grupos de carcinomas de boca em relação a imuno-histoquímica e o perfil de metilação do gene da Ecaderina

Probabilidade de sobrevida acumulada pela técnica de Kaplan-Meier

\begin{tabular}{|c|c|c|c|c|c|}
\hline \multirow{2}{*}{ E-caderina } & \multicolumn{4}{|c|}{ Sobrevida Livre de Doença } & \multirow[b]{2}{*}{$p^{*}$} \\
\hline & & $\mathrm{CV}$ & CEC-pNO & CEC-pN+ & \\
\hline \multicolumn{6}{|l|}{ IMH (MBC) } \\
\hline \multirow{2}{*}{$\leq 36,5 \%$} & $5 \operatorname{anos}(\%)$ & 100 & 90 & 67 & \multirow{2}{*}{$\mathbf{0 , 0 3 6}$} \\
\hline & $10 \operatorname{anos}(\%)$ & 100 & 90 & 53 & \\
\hline \multirow{2}{*}{$>36,5 \%$} & $5 \operatorname{anos}(\%)$ & 84 & 79 & 40 & \multirow{2}{*}{0,040} \\
\hline & $10 \operatorname{anos}(\%)$ & 68 & 79 & 40 & \\
\hline \multicolumn{6}{|l|}{ Metilação } \\
\hline \multirow{2}{*}{ Metilado } & $5 \operatorname{anos}(\%)$ & 80 & 83 & 45 & \multirow{2}{*}{0,062} \\
\hline & $10 \operatorname{anos}(\%)$ & 80 & 83 & 30 & \\
\hline \multirow{2}{*}{ Não metilado } & $5 \operatorname{anos}(\%)$ & 67 & 87 & 81 & \multirow{2}{*}{0,611} \\
\hline & $10 \operatorname{anos}(\%)$ & 33 & 87 & 81 & \\
\hline
\end{tabular}

$\overline{\mathrm{CV} \text { : Carcinoma Verrucoso, CEC-pN0: Carcinoma Espinocelular Bem Diferenciado sem }}$ comprometimento linfonodal, CEC-pN+: Carcinoma Espinocelular Bem Diferenciado com comprometimento linfonodal, IMH: Imuno-histoquímica, MBC: Marcação Membranosa Completa

$p^{*}$ : valor obtido pelo teste de logrank considerando-se nível de significância de $5 \%$ 
6 DISCUSSÃO 


\section{DISCUSSÃO}

O carcinoma verrucoso é considerado uma forma rara e indolente do carcinoma espinocelular bem diferenciado, principalmente por apresentar uma evolução clínica com algumas características de tumor benigno. Dentre estas pode-se citar o crescimento lento, padrão evolutivo mais expansivo do que invasivo e um alto grau de diferenciação celular ${ }^{1,54,70}$.

Que fatores estariam envolvidos no comportamento biológico desta lesão maligna que fazem com que os pacientes acometidos tenham um bom prognóstico? Sendo uma variante do carcinoma espinocelular, por que no carcinoma verrucoso o crescimento expansivo ao contrário do padrão infiltrativo típico das neoplasias malignas, ocorre mais freqüentemente? Qual a prevalência do CV na boca e quais as principais áreas anatômicas afetadas por esta neoplasia maligna?

Estes, entre outros questionamentos relacionados ao carcinoma verrucoso bucal nortearam a realização do presente estudo visando contribuir com o conhecimento sobre o comportamento clínico e biológico desta neoplasia maligna quando de sua ocorrência na cavidade bucal.

No Brasil, existem poucos trabalhos sobre o CV na cavidade bucal ${ }^{10,20,32,75}$ e a maioria consiste em descrições de casos clínicos ${ }^{10,20,32}$.

Em nosso estudo retrospectivo dos pacientes acometidos por carcinoma verrucoso bucal, de 1980 a 2000, no Hospital do Câncer A.C.Camargo-São Paulo, a freqüência de CV obtida foi de $0,6 \%$ dentre os 1613 carcinomas espinocelulares primários da cavidade bucal avaliados (Tabela 1). Esta freqüência foi inferior àquela encontrada na literatura, que varia de 
1 a $10 \%$, sendo os maiores percentuais encontrados nos trabalhos realizados na Índia ${ }^{7,12,25,48,61,63,65,69,70,82}$. No entanto $\mathrm{KOCH}$ et $\mathrm{al}^{54}$, em 2001, observaram que dos 411.534 carcinomas da região de cabeça e pescoço, diagnosticados no National Cancer Data Base (NCDB), no período de 1985 a 1996 nos Estados Unidos da América, 2350 (0,6\%) eram CVs , sendo que $1314(0,3 \%)$ acometeram a cavidade bucal.

Observamos uma maior ocorrência de carcinoma verrucoso bucal em pacientes do gênero masculino (60\%), da raça branca (90\%) e com idade avançada (média de 67,8 anos). Quanto à localização, a maioria dos CVs ocorreu no lábio inferior (40\%) seguido pela gengiva inferior $(20 \%)$ e palato duro (20\%). Regiões como mucosa jugal e palato mole também foram acometidas pelo tumor (Tabela 2). Todas estas características demográficas e clínicas, com pequenas diferenças, são semelhantes àquelas verificadas por outros autores $1,7,8,11,12,24,25,48,54,56,61,63,70,82$.

O tempo de história clínica foi superior ou igual a 16 meses em $60 \%$ dos CVs em nossa amostra, o que reflete o crescimento lento e indolente desta lesão. Dos pacientes analisados por MCCOY e WALDRON ${ }^{61}$, a maioria estava acometida pela lesão há vários anos, sendo que um deles relatou tê-la há 14 anos e sem sintoma doloroso.

Desde sua descrição inicial, muitas controvérsias existem sobre os fatores etiológicos envolvidos na patogenia do carcinoma verrucoso. Os relatos de FRIEDELL e ROSENTHAL ${ }^{34}$, em relação às lesões verrucóides da cavidade bucal, e posteriormente os de $\mathrm{ACKERMAN}^{1}$, que associou o $\mathrm{CV}$ ao tabaco sem fumaça, fizeram com que este vício fosse reportado como uma das principais causas relacionadas a lesão ${ }^{11,12,24,50,54,56,70,82}$, entretanto, outros autores ${ }^{7,52,58,61}$ não conseguiram estabelecer esta associação. Uma provável atividade viral oportunista associada à ação crônica dos carcinógenos, como o tabaco e o álcool, na patogênese do carcinoma verrucoso também foi sugerida ${ }^{2,25,59,66,72}$. 
$\mathrm{Na}$ análise dos 426 carcinomas verrucosos de boca realizado por RAJENDRAN et al. ${ }^{70}$, em 1988, todos os pacientes eram tabagistas e a grande maioria mascava betel associado ou não ao tabaco. Deve ser ressaltado, no entanto que este estudo foi realizado no Sul da Índia, onde a freqüência do tabagismo é elevada.

Em nossa amostra o tabagismo e o etilismo estavam presentes em 60 e $90 \%$ dos pacientes com CV, respectivamente (Tabela 3). Todos os pacientes etilistas eram tabagistas e a grande maioria relatou fazer uso de cigarro de papel. Esses resultados reforçam os achados de outros autores ${ }^{11,12,50,54,56,70}$ em que o etilismo e o tabagismo foram fatores de risco freqüentemente observados nos pacientes com carcinoma verrucoso bucal, no entanto, nenhuma associação com o tabaco sem fumaça foi verificada em nosso estudo.

No momento do diagnóstico, observou-se um aspecto clínico ulcerovegetante na maioria dos CVs bucais (Tabela 4) e todas as lesões apresentavam-se em estádios iniciais (I e II), confirmando os resultados de JYOTHIRMAYI et al. ${ }^{48}$ e $\mathrm{KOCH}$ et al. ${ }^{54}$, que verificaram uma freqüência de CV em estádios iniciais, superior a 70\% nos pacientes estudados.

Nenhum dos pacientes com carcinoma verrucoso desenvolveu metástase a distância ou regional, confirmando o baixo potencial de invasão tecidual da lesão, como verificado também por outros autores ${ }^{1,11,48,56,61}$. Segundo ACKERMAN ${ }^{1}$, clinicamente, devido à presença de infecções secundárias concomitantes a lesão, os linfonodos podem se tornar enfartados levando ao diagnóstico equivocado de metástase locorregional.

Por outro lado, FERLITO; RINALDO; MANNARA ${ }^{30}$ e FERLITO et al. ${ }^{31}$ afirmam que as metástases a distância associadas com CV podem ser conseqüência de um diagnóstico incorreto ou da presença de focos de carcinomas espinocelulares em lesões com características verrucosas. Portanto, para um diagnóstico seguro e confiável do carcinoma verrucoso é 
necessário uma biópsia adequada, que deve ser cuidadosamente avaliada ao microscópio pelo patologista $^{7,30,31,54,65,82}$.

Uma interessante revisão de $2350 \mathrm{CVs}$ foi realizada por $\mathrm{KOCH}$ et al. ${ }^{54}$, e alguns espécimes relatados com metástase regional ou a distância, foram revistos microscopicamente e reclassificados como carcinoma espinocelular papilar ou como carcinoma espinocelular bem diferenciados com características verrucosas.

Em nosso estudo, todos os pacientes com $\mathrm{CV}$ foram submetidos à cirurgia como tratamento de escolha para esta neoplasia.

A radioterapia e/ou a quimioterapia podem ser utilizadas como tratamento inicial do carcinoma verrucoso naqueles pacientes considerados inoperáveis devido a lesões extensas ou alterações sistêmicas que comprometam a cirurgia ${ }^{48,54,69,90,100}$.

Embora alguns autores ${ }^{24,31,100}$ reforçam a possibilidade de transformação do CV para neoplasias mais agressivas após o emprego da radioterapia como tratamento de escolha, outros 54,65 afirmam que muitas destas alterações neoplásicas atípicas associadas à radioterapia são conseqüências de biópsias superficiais em carcinomas espinocelulares com características verrucosas.

Em nossa amostra, nenhum paciente com $\mathrm{CV}$ foi submetido ao tratamento radioterápico e/ou quimioterápico complementar ao tratamento cirúrgico (Tabela 5), o que segundo $\mathrm{KOCH}$ et al. ${ }^{54}$, estaria indicado para os casos em que houvesse uma maior preocupação com as margens cirúrgicas.

Com relação à evolução clínica tumoral, verificamos que em $40 \%$ dos pacientes com carcinoma verrucoso bucal houve recidiva local desta neoplasia, sendo esta freqüência semelhante à verificada por JACOBSON e $\operatorname{SHEAR}^{46}(40 \%)$, no entanto, mostrou-se maior 
quando comparada aos relatos de ACKERMAN ${ }^{1}$ (29\%), JYOTHIRMAYI et al. ${ }^{48}(30,1 \%)$, KRAUS e PEREZ-MESA ${ }^{56}(11,7 \%)$ e RAJENDRAN et al. ${ }^{70}(6,12 \%)$.

Segundo alguns autores ${ }^{46,61}$, as recorrências do CV ocorrem principalmente porque, devido ao crescimento lento e indolente da lesão associado ao seu baixo potencial metastático, as ressecções cirúrgicas tumorais são realizadas de forma inadequada mantendo as margens cirúrgicas comprometidas. No entanto, em nossa amostra todos os CVs bucais apresentavam margens cirúrgicas livres de comprometimento neoplásico.

A presença de um segundo tumor primário foi verificada em $20 \%$ dos pacientes com carcinoma verrucoso bucal (Tabela 5), freqüência esta mais elevada do que aquela observada por KRAUS e PEREZ-MESA ${ }^{56}$, que constataram um segundo tumor em $8(10,4 \%)$ dos 77 CVs de boca analisados.

Microscopicamente, os CVs estudados foram determinados com base nas características descritas inicialmente por ACKERMAN ${ }^{1}$ em 1948. Todos os espécimes com aspectos microscópicos típicos do carcinoma verrucoso, porém com invasão tecidual foram incluídos como carcinoma espinocelular bem diferenciado.

As alterações microscópicas epiteliais observadas nos CVs em nossa amostra foram discretas e características desta neoplasia. O tecido epitelial apresentava-se hiperplásico e com acantose intensa na maioria dos espécimes (Tabela 6 e Figura 3). As lesões eram exofíticas, verrucosas e com fendas epiteliais preenchidas por queratina (Figura 3). Queratinização intensa foi verificada em $80 \%$ das amostras (Tabela 6). Essas características microscópicas estão de acordo com os critérios de ACKERMAN $^{1}$ e com os observados em outros $\operatorname{estudos}^{54,61,71}$. A ausência de uma intensa e típica queratinização em uma neoplasia maligna epitelial, segundo JACOBSON e SHEAR ${ }^{46}$, não deve excluir o diagnóstico de carcinoma 
verrucoso, pois esta lesão pode acometer também regiões não queratinizadas como o assoalho bucal adquirindo características microscópicas de lesões benignas da mucosa bucal.

As cristas epiteliais interpapilares, em nossa amostra, eram largas e longas e pareciam "empurrar" o tecido conjuntivo adjacente (Figura 3). Essas cristas apresentavam, em $50 \%$ dos espécimes, pleomorfismo e hipercromatismo celular moderados (Tabela 6 e Figura 4), denotando pouca atipia, entretanto, estudos como o de RAJENDRAN et al. ${ }^{71}$, relataram uma atipia celular moderada em apenas $11,5 \%$ dos CVs.

A membrana basal íntegra consiste em uma característica marcante dos CVs e, assim como em outros estudos ${ }^{1,61,71}$, foi observada, em nossa amostra, na grande maioria $(90 \%)$ dos carcinomas verrucosos bucais analisados (Figura 4). Em apenas um espécime detectou-se uma área focal de membrana basal descontínua que parecia ser decorrente da exocitose por células inflamatórias mononucleares que invadiam o epitélio mimetizando uma reação liquenóide (Figura 5).

Ao contrário do carcinoma espinocelular, que geralmente invade o tecido conjuntivo adjacente formando cordões e ilhotas epiteliais grossos ou finos, o CV parece "empurrar" o tecido conjuntivo, caracterizando o padrão de invasão compressivo. Nossa casuísta mostrou que todos os espécimes apresentavam este comportamento (Figura 3), corroborando com as observações de outros autores ${ }^{1,11,54,61,68}$.

Um aspecto microscópico descrito por MCCOY e WALDRON ${ }^{61}$ e RAJENDRAN et al. ${ }^{71}$, e demonstrado em nossa amostra foram as poucas figuras de mitoses, geralmente típicas, detectadas nos carcinomas verrucosos bucais (Figura 4).

A observação mais proeminente no tecido conjuntivo dos carcinomas verrucosos bucais foi a presença de um discreto infiltrado inflamatório mononuclear difusamente distribuído, também verificada em outros estudos sobre esta neoplasia maligna ${ }^{1,31,54,56,61,75}$ 
(Figuras 3 e 4). SANT'ANA FILHO e ROVANI ${ }^{75}$ sugeriram que a presença deste infiltrado inflamatório mononuclear poderia constituir um dos mecanismos limitantes da invasão tecidual desta neoplasia.

Por outro lado, a presença de exocitose e de células inflamatórias polimorfonucleares em $40 \%$ da nossa amostra (Tabela 6 ) pode estar refletindo a presença de infecção secundária sobreposta à neoplasia, como a candidose que foi descrita por alguns autores $^{46,84}$ (Figura 5). Para JACOBSON e $\mathrm{SHEAR}^{46}$ as fendas presentes na superfície do carcinoma verrucoso poderiam atuar como áreas de estagnação para microrganismos, atraindo células inflamatórias para os tecidos epiteliais simulando microscopicamente uma intensa atipia celular.

Embora o carcinoma verrucoso seja freqüentemente curável nos estádios precoces, esta neoplasia pode se tornar localmente agressiva, se não tratada, e invadir músculos, ossos, glândulas salivares e cartilagens ${ }^{1,24,54,61,71}$. Em nenhum dos CVs analisados microscopicamente em nosso estudo, foi verificada infiltração dos tecidos neurais, musculares, ósseos, glandulares e embolização vascular e/ou linfática. RAJENDRAN et al. ${ }^{71}$ relataram no estudo de CV, 53\% de invasão dos tecidos ósseos, musculares e glandulares. Quanto à invasão perineural, dos onze CVs de boca analisados por DEMIAN; BUSHKIN; ECHEVARRIA ${ }^{24}$, apenas um apresentou comprometimento neoplásico deste tecido.

A diferenciação microscópica entre carcinoma verrucoso e carcinoma espinocelular, principalmente a variante papilar, é de fundamental importância para o tratamento proposto e análise da evolução dos pacientes ${ }^{1,30,31,54,65}$. Muitas vezes, lesões que são clinicamente compatíveis com $\mathrm{CV}$ e apresentam biópsia incisional com este diagnóstico podem, ao serem cirurgicamente removidas e microscopicamente analisadas, diagnosticadas como CEC bem diferenciado. Em nosso levantamento, encontramos uma biópsia incisional em que foi 
sugerida o diagnóstico de carcinoma verrucoso, mas a análise microscópica da peça cirúrgica removida revelou que era um CEC bem diferenciado.

Assim sendo, alguns autores ${ }^{7,30,31,65,82}$ são enfáticos ao afirmarem que somente uma biópsia adequada e não superficial associada a uma minuciosa avaliação microscópica por parte do patologista permitirá um diagnóstico seguro e confiável do carcinoma verrucoso.

Levando-se em consideração que um dos traços mais instigantes quanto ao comportamento biológico do carcinoma verrucoso consiste no seu baixo potencial de invasão tecidual e desenvolvimento de metástases ${ }^{1,2,7,11,24,31,46,54,56,61,71,75,82}$, também foi objetivo desta dissertação, avaliar algumas das alterações moleculares envolvidas na adesão célula-célula, especificamente relacionadas à molécula da E-caderina. Uma melhor compreensão das etapas moleculares envolvidas na biologia tumoral é essencial tanto para o estabelecimento da evolução e prognóstico dos pacientes quanto para o desenvolvimento de terapias anticâncer.

Avaliamos o perfil de metilação do gene da E-caderina e a expressão imunohistoquímica desta molécula de adesão nos carcinomas verrucosos comparando os resultados obtidos com dois grupos de carcinomas espinocelulares bem diferenciados, sem (CEC-pN0) e com (CEC-pN+) comprometimento linfonodal (Tabelas 7 a 17).

Recentemente, uma atenção especial tem sido dada na utilização da metilação como um marcador molecular em diferentes tipos de câncer $5,14,15,22,23,26,28,35,41,47,78,80,89,102$. Uma vantagem do uso da metilação como marcador molecular é que, ao contrário das mutações, que ocorrem em inúmeras regiões de um dado gene e podem ser de muitos tipos, a metilação ocorre sempre na mesma região. Além disso, a metilação pode ser detectada mesmo no meio de uma grande quantidade de células normais, enquanto que outras alterações genéticas como a perda de heterozigose ( $\mathrm{LOH}$ ) ou deleções homozigóticas não são detectadas nesse contexto $^{22}$. 
Especificamente quanto ao perfil de metilação do gene da E-caderina em carcinomas verrucosos de boca, nenhum trabalho foi encontrado na literatura científica pesquisada.

Em nosso estudo, a hipermetilação do gene da E-caderina foi observada em mais de $50 \%$ dos espécimes analisados nos três grupos de carcinomas (CV, CEC-pN0 e CEC-pN+), no entanto, nenhuma diferença estatística entre os mesmos foi verificada $(p=0,975)$ como pode ser observado na Tabela 7. Os percentuais de hipermetilação do gene da E-caderina em carcinomas espinocelulares de boca são bastante variados: $85,4 \%$ (YEH et al. ${ }^{97}$ ), 78,2\% (NAKAYAMA et al. $^{64}$ ), $72 \%$ (KUDO et al. $^{57}$ ), $64 \%$ (CHANG et al. $\left.^{14}\right), \quad 35 \%$ (VISWANATHAN; TSUCHIDA; SHANMUGAM ${ }^{91}$ ), e em carcinomas de cabeça e pescoço, 36,5\% (HASEGAWA et al. ${ }^{41}$ ). Nestes estudos ${ }^{14,41,57,64,91,97}$, as diferentes técnicas utilizadas para a determinação da hipermetilação gênica da E-caderina nos carcinomas espinocelulares e a diversidade de fatores que influenciam o comportamento clínico e biológico destes tumores como a localização das lesões, o estadiamento clínico no momento do diagnóstico, a modalidade de tratamento, o grau de diferenciação celular entre outros, tornam inviável a comparação entre os resultados obtidos.

Um aspecto interessante foi observado por HASEGAWA et al. ${ }^{41}$, que relataram uma associação entre os espécimes que apresentavam hipermetilação do gene da E-caderina e o vício do tabaco, principalmente em relação à quantidade de cigarros fumados, em pacientes com carcinomas espinocelulares de boca. Em nossa amostra verificamos que nos grupos de CECs (CEC-pN0 e CEC-pN+) a hipermetilação da E-caderina ocorreu, principalmente nos pacientes tabagistas e etilistas, entretanto no grupo dos CVs a distribuição dos pacientes foi eqüitativa (Tabela 8).

YEH et al. ${ }^{97}$ sugeriram que a hipermetilação da E-caderina ocorre precocemente na evolução tumoral, ao observarem que 33\% das margens cirúrgicas tumorais analisadas, livres 
de comprometimento neoplásico, apresentavam-se hipermetiladas. Nossos resultados (Tabela 7) corroboram com a sugestão destes autores ${ }^{97}$ e reforçam a teoria de que a hipermetilação do gene da E-caderina pode ser um evento epigenético precoce nos carcinomas espinocelulares de boca ocorrendo inclusive naquelas neoplasias malignas com baixo potencial invasivo e metastático como nos carcinomas verrucosos.

Além de também considerarem que a hipermetilação de genes supressores de tumor ocorra em fases iniciais da progressão tumoral, TOYOTA e ISSA ${ }^{89}$ sugeriram, baseados em seus estudos sobre vários tipos de câncer em diferentes áreas anatômicas, que essa alteração epigenética, de um modo geral, é idade dependente, ou seja, as pessoas mais idosas apresentam uma maior quantidade de genes hipermetilados. Em nossa amostra, a hipemetilação do gene da E-caderina foi observada, principalmente, nos pacientes com idade inferior a 59 anos, como pode ser observado na Tabela 8, não sendo observada nenhuma associação entre a presença da hipermetilação e as idades dos pacientes.

Com a finalidade de verificar a ocorrência de hipermetilação do gene da E-caderina em mucosa bucal sem sinais de malignidade, realizamos análise de cinco hiperplasias fibrosas inflamatórias e nenhuma apresentou tal alteração. Esses resultados reforçam aqueles encontrados por VISWANATHAN; TSUCHIDA; SHANMUGAM ${ }^{91}$ que relataram a ausência de hipermetilação do gene da E-caderina em 25 espécimes livres de comprometimento neoplásico (não consistiam de margens tumorais), obtidos de pacientes com carcinomas de boca e confirmam a constatação de que a hipermetilação do gene da E-caderina está freqüentemente associada ao fenótipo maligno das células epiteliais.

Quanto ao gênero dos pacientes, verificamos que houve uma predileção pelo gênero masculino nos grupos dos CECs bem diferenciados (Tabela 8), em que a hipermetilacão da Ecaderina foi observada. HASEGAWA et al. ${ }^{41}$, ao analisarem a ocorrência de hipermetilação 
dos genes da E-caderina, p16 ${ }^{\mathrm{INK} 4 \mathrm{a}}$, DAP-Kinase e RASSF1A em carcinomas espinocelulares da região de cabeça e pescoço, verificaram que, dentro dos indivíduos que apresentaram pelo menos um desses genes metilados, $75 \%$ eram do gênero masculino.

Quanto às características clínicas e microscópicas, HASEGAWA et al. ${ }^{41}$, não observaram nenhuma relação entre os estádios $\mathrm{T}$ e $\mathrm{N}$ dos pacientes com carcinomas espinocelulares e a hipermetilação da E-caderina. Em nossa amostra, houve uma semelhante distribuição entre os tumores com estádios T iniciais (T1 e T2) e avançados (T3 e T4) que estavam hipermetilados para E-caderina, tanto no grupo CEC-pN0 quanto no grupo CEC-pN+ (Tabela 9).

Segundo CHANG et al. ${ }^{14}$, a ocorrência de hipermetilação da E-caderina poderia ser um dos fatores responsáveis pelas recidivas locais e metástases regionais dos carcinomas espinocelulares bucais. Um aspecto interessante dos nossos resultados foi que, no grupo CEC$\mathrm{pN}+$ das oito recidivas que ocorreram, seis (75\%) estavam com o gene da E-caderina hipermetilado (Tabela 10).

Além disso, como já propuseram alguns autores ${ }^{14,15,17,38,57,101}$, a hipermetilação da região promotora do gene da E-caderina parece ser instável refletindo um processo dinâmico e heterogêneo. Assim sendo, numa mesma neoplasia existiriam células com diferentes potenciais de invasão e a perda de expressão da E-caderina por hipermetilação, sendo um evento reversível, seria fundamental para a progressão tumoral. Com base nesta teoria ${ }^{14,15,17,38,57,101}$ e em nossos resultados, a hipermetilação da E-caderina ocorreria inicialmente nos carcinomas bem diferenciados para permitir que as células epiteliais malignas adquiram capacidade de invadir os tecidos adjacentes e numa segunda etapa o restabelecimento da transcrição gênica desta molécula de adesão ocorreria assim, que estas células atingissem um local diferente do sítio primário do tumor (foco metastático). 
Um aspecto interessante foi relatado por KUDO et al. ${ }^{57}$ ao avaliarem, por meio da técnica da microdissecção a laser, a hipermetilação do gene da E-caderina em diferentes áreas tumorais dentro da mesma neoplasia. Esses autores constataram que em todos os espécimes que hipermetilaram, a presença deste evento epigenético ocorria apenas nas áreas mais invasivas em detrimento às não invasivas.

Para as análises da expressão imuno-histoquímica da E-caderina, optamos por avaliar o front de invasão tumoral dos CVs e CECs porque os eventos moleculares importantes para a disseminação tumoral como aquisição e perda de moléculas de adesão, secreção de enzimas proteolíticas, aumento da proliferação celular e angiogênese ocorrem essencialmente na interface tumor-hospedeiro ${ }^{9}$.

A análise imuno-histoquímica da marcação membranosa completa da E-caderina nos grupos de carcinomas estudados revelou uma média maior para o grupo dos CVs quando comparado aos grupos de CECs bem diferenciados (CEC-pN0 e CEC-pN+), sendo esta diferença estatisticamente significativa, como pode ser observado na Tabela 11.

Quando os valores foram dicotomizados, mais de $80 \%$ dos CVs continham MBC superior a $36,5 \%$, seguido por $50 \%$ dos CEC-pN0 e somente $29 \%$ dos CEC-pN+. A maioria dos CECs com comprometimento linfonodal (71\%) apresentava expressão de E-caderina com valor menor ou igual a 36,5\% (Tabela 12), confirmando as afirmações de alguns autores ${ }^{76,96} \mathrm{de}$ que a perda da expressão da E-caderina realmente consiste em um evento importante para a invasão e disseminação metastática tumoral.

Com relação as características clínicas e a distribuição da expressão imunohistoquímica de E-caderina nossos resultados (Tabela 13) concordam com aqueles encontrados por $\mathrm{CHOW}$ et al. ${ }^{16}$, que não observaram nenhuma diferença estatisticamente 
significativa entre a expressão imuno-histoquímica da E-caderina e o gênero e a idade dos pacientes acometidos por carcinoma espinocelular de língua.

Em nossa amostra nos grupos de CECs bem diferenciados (CEC-pN0 e CEC-pN+) houve uma predileção, nos espécimes com MBC inferior ou igual a 36,5\%, pelo gênero masculino (Tabela 13) e em relação ao estádio T (Tabela 14), houve uma distribuição eqüitativa entre os carcinomas espinocelulares (CEC-pN0 e CEC-pN+) que possuíam estádios iniciais (T1 e T2) e estádios avançados (T3 e T4). Por outro lado, quanto ao estádio clínico N, no grupo CEC-pN+ a maioria dos pacientes, com nódulos palpáveis clinicamente, apresentou MBC inferior ou igual a 36,5\% (Tabela 14).

Autores como MATTIJSSEN et al. ${ }^{62}$, não observaram nenhuma correlação entre os estádios clínicos $\mathrm{T}$ e $\mathrm{N}$ dos pacientes com CEC de boca e a expressão imuno-histoquímica da E-caderina, entretanto, esta correlação foi verificada por YAMADA et al. ${ }^{96}$ sendo que os pacientes com estádios mais avançados (T3 e T4) e que clinicamente apresentavam nódulos palpáveis mostravam uma maior redução da expressão da E-caderina.

A perda ou redução da expressão imuno-histoquímica da E-caderina em carcinomas espinocelulares da região de cabeça e pescoço foi associada com uma maior freqüência de metástase regional ${ }^{76,96}$. CHOW et al. ${ }^{16}$ além desta correlação também verificaram que os carcinomas espinocelulares que apresentaram mais recidivas locais mostraram menor expressão desta molécula de adesão.

Nossos resultados revelaram que houve uma diferença estatisticamente significativa quanto à expressão imuno-histoquímica da E-caderina, entre os carcinomas verrucosos e os grupos de carcinomas espinocelulares bem diferenciados com comprometimento linfonodal (Tabela 17). Esses resultados corroboram com os de TANG; ZOU; XIE ${ }^{87}$ e TIAN; GUO; 
$\mathrm{ZHANG}^{88}$, em que foi verificado diferença entre à expressão imuno-histoquímica da Ecaderina nos CV e CECs da cavidade bucal.

No grupo CEC-pN+, entre os espécimes que tiveram recidivas locais, a maioria possuía expressão de E-caderina com MBC inferior ou igual a 36,5\%, refletindo uma maior perda de expressão imuno-histoquímica desta molécula de adesão. Um aspecto curioso foi que o único carcinoma verrucoso que teve $\mathrm{MBC}$ inferior ou igual a 36,5\% apresentou recidiva local (Tabela 15).

Ao associarmos os valores obtidos da expressão imuno-histoquímica da E-caderina com os verificados quanto ao perfil de metilação do gene que codifica essa molécula, não foi encontrada nenhuma diferença estatística nos grupos CV e CEC-pN0 (Tabela 16).

No grupo CEC-pN+, houve uma associação estatisticamente significativa $(p=0,044)$ entre o perfil de metilação do gene da E-caderina e a expressão imuno-histoquímica desta molécula (Tabela 16), no entanto foi oposta à associação descrita na literatura. Alguns autores ${ }^{14,57,64,97}$ verificaram que os CECs de boca que possuíam hipermetilação do gene da Ecaderina apresentavam maior perda ou redução da expressão imuno-histoquímica desta molécula. Em nosso grupo CEC-pN+, os espécimes que hipermetilaram estavam igualmente distribuídos entre a expressão imuno-histoquímica da E-caderina com valores $\leq 36,5 \% \mathrm{MBC}$ e $>36,5 \% \mathrm{MBC}$. Por outro lado, todos os carcinomas espinocelulares com comprometimento linfonodal que não apresentavam metilação do gene da E-caderina possuíam redução da expressão de E-caderina com valor inferior ou igual a 36,5\% MBC (Tabela 16).

A análise da perda ou redução imuno-histoquímica da E-caderina isoladamente pode ser conflitante pois esta molécula faz parte de uma complexa rede de adesão celular influenciada por fatores ambientais locais ${ }^{3,4,6,16,39,81,86,93,95,101}$ e segundo CHRISTOFORI e SEMB $^{17}$, CONACCI-SORRELL et al. ${ }^{19}$, YOKOYAMA et al. ${ }^{98}$, além dos eventos 
epigenéticos a atuação de outros repressores transcricionais, bem como as alterações genéticas, podem também levar à perda ou à redução da expressão da E-caderina.

As correlações entre a reduzida expressão imuno-histoquímica e a ocorrência de hipermetilação do gene da E-caderina observadas na literatura são decorrentes de comparações realizadas entre carcinomas espinocelulares bem, moderadamente e pouco diferenciados ${ }^{14,97}$ ou de experimentos em que a maioria das amostras apresentava reduzida expressão imunohistoquímica da E-caderina ${ }^{57,64}$. De acordo com as verificações de alguns autores ${ }^{62,76,96}$, há uma associação direta entre a expressão imuno-histoquímica da E-caderina e o grau de diferenciação celular dos carcinomas espinocelulares, ou seja, os carcinomas moderadamente e pouco diferenciados com fenótipo mais agressivo tem uma expressão reduzida desta molécula de adesão quando comparados aos bem diferenciados.

Nossa amostra foi composta basicamente por carcinomas espinocelulares bem diferenciados e uma de suas variantes, onde uma diferença significativa e sugestiva entre a expressão imuno-histoquímica da E-caderina foi observada quando o grupo CV foi comparado aos grupos CEC-pN+ e CEC-pN0, respectivamente. Quando os grupos de carcinomas espinocelulares bem diferenciados sem e com comprometimento linfonodal foram associados, como pode ser observado na Tabela 17, nenhuma diferença estatisticamente significativa entre a expressão de E-caderina foi observada.

A influência da morfologia tumoral no prognóstico dos pacientes portadores de $\mathrm{CV}$, CEC-pN0 e CEC-pN+, revelou uma diferença estatisticamente significativa na comparação entre as curvas de sobrevida global $(p=0,012)$ como pode ser observado na Tabela 18 e Figura 10.

Quando a sobrevida global é analisada em cinco anos nota-se que, entre os grupos de carcinomas espinocelulares sem comprometimento linfonodal, a porcentagem de pacientes 
vivos dos grupos CV e CEC-pN0, (87,5 e 85\%, respectivamente) são próximas e bem mais elevadas se comparadas com o grupo CEC-pN+ (35,2\%). Em dez anos, o valor foi de 65,6\% para o grupo CV e 55,0 e 29,1\% para os grupos de carcinomas espinocelulares, respectivamente, CEC-pN0 e CEC-pN+ (Tabela 18).

$\mathrm{KOCH}$ et al. ${ }^{54}$ verificaram ao analisarem $2350 \mathrm{CVs}$ da região de cabeça e pescoço uma sobrevida global com taxas de 61,1 e $40 \%$ em cinco e dez anos, respectivamente. Em nossa amostra, os CVs eram exclusivos de boca e as taxas de sobrevida global observadas em cinco e dez anos (Tabela 18) foram superiores àquelas encontradas por estes autores.

Para o grupo de carcinomas espinocelulares com comprometimento linfonodal $(\mathrm{CEC}-\mathrm{pN}+)$, os baixos valores percentuais de pacientes vivos (Tabela 18) corroboram com os encontrados por alguns autores ${ }^{76,96}$ que relataram pior prognóstico para os pacientes com CEC e comprometimento linfonodal.

Por outro lado, nossos resultados seguem a mesma tendência relatada por JYOTHIRMAYI et al. ${ }^{48}$ que observaram em seu estudo, sobrevida global em cinco anos de $86 \%$ para os pacientes portadores de carcinoma verrucoso de boca e $56 \%$ para os pacientes com carcinoma espinocelular bem diferenciado, sendo que os pacientes que foram diagnosticados em estádios clínicos avançados (III e IV) apresentaram os piores prognósticos.

Quanto à sobrevida livre de doença verificamos que tanto para cinco como dez anos, respectivamente, os valores percentuais do grupo CV $(65,6$ e 52,4\%) situaram entre o grupo CEC-pN0 (84,8 e 84,8\%), que apresentou os maiores valores, e o grupo CEC-pN+ (57,7 e 48,1\%). Esses valores percentuais de sobrevida livre de doença para o grupo CV refletem principalmente, os percentuais de recidiva da lesão obtidos tanto no estudo de JYOTHIRMAYI et al. $^{48}(30,1 \%)$, e especificamente no nosso $(40 \%)$, que foi superior ao observado para o grupo CEC-pN0 (20\%) como pode ser verificado na Tabela 18 e Figura 11. 
Quando as curvas de sobrevida global, dos três grupos de carcinomas, são avaliadas quanto à expressão imuno-histoquímica da E-caderina, verificamos uma diferença sugestiva $(p=0,066)$ para os espécimes que apresentaram MBC inferior ou igual a 36,5\%. Em cinco anos, os percentuais dos pacientes dos grupos CV e CEC-pN0 foram, respectivamente, 100 e $90 \%$ e destoaram do grupo CEC-pN+ (42\%). No entanto, em dez anos, o valor do grupo CV se manteve, mas os percentuais dos grupos de carcinomas reduziram sendo, $60 \%$ para o grupo CEC-pN0 e 33\% para o grupo CEC-pN+ (Tabela 19).

A análise destes dados sugere que os carcinomas espinocelulares que apresentaram menor expressão de E-caderina com valores inferior ou igual a 36,5\% $\mathrm{MBC}(11 \% \mathrm{CV}, 50 \%$ CEC-pN0 e 71\% CEC-pN+) apresentaram pior prognóstico, entretanto em função da reduzida amostra de CV outros estudos são necessários para confirmarem esta tendência. Em relação aos carcinomas com expressão imuno-histoquímica de E-caderina superior a 36,5\% MBC nenhuma diferença estatística foi detectada entre os diferentes grupos tumorais (Tabela 19).

A comparação das curvas de sobrevida global dos grupos em relação ao perfil de metilação do gene da E-caderina mostrou uma diferença estatisticamente significativa ( $\mathrm{p}=$ 0,031), entre os espécimes que não metilaram (Tabela 19). Entretanto entre as amostras que metilaram uma diferença estatística sugestiva $(p=0,072)$ foi encontrada como pode ser observado na Tabela 19. Tanto para cinco quanto dez anos, para os dois padrões de metilação, a taxa de sobrevida do carcinoma verrucoso foi superior a verificada nos grupos de carcinomas espinocelulares (CEC-pN0 e CEC-pN+).

Quanto à sobrevida livre de doença, nos períodos de cinco e dez anos, em relação à expressão imuno-histoquímica da E-caderina (Tabela 20), verificou-se diferença estatisticamente significativa entre os grupos de carcinomas (CV, CEC-pN0 e CEC-pN+) tanto para os espécimes com MBC inferior ou igual a $36,5 \%(p=0,036)$ quanto para os valores 
superiores $(p=0,040)$. Nos grupos de carcinomas sem comprometimento linfonodal (CV e CEC-pN0) as taxas de sobrevida dos pacientes foram superiores aos do grupo CEC-pN+ para ambos padrões de expressão imuno-histoquímica de E-caderina $(>36,5 \% \mathrm{MBC}$ e $\leq 36,5 \%$ $\mathrm{MBC})$.

Um aspecto curioso ao observarmos a Tabela 20 consiste em uma menor taxa de sobrevida livre de doença para os paciente com CV quando comparado ao CEC-pN0 em dez anos no grupo de carcinomas que não apresentavam metilação do gene da E-caderina, entretanto esta diferença não foi estatisticamente significativa $(p=0,611)$. Esses resultados refletem o padrão de recidiva entre os dois grupos (CV e CEC-pN0) e confirmam que as recidivas no grupo dos CVs (20\% dos espécimes com recidiva local) embora percentualmente iguais as do grupo CEC-pN0, ocorreram no período entre cinco e dez anos.

As taxas de sobrevida livre de doença nos carcinomas com hipermetilação do gene da E-caderina, sugerem diferenças entre as amostras que metilaram $(p=0,062)$. Os percentuais dos grupos $\mathrm{CV}$ e CEC-pN0 foram próximos, diferindo do grupo $\mathrm{CEC}-\mathrm{pN}+$, tanto para cinco como dez anos (Tabela 20). Em relação aos carcinomas avaliados (CV, CEC-pN0 e CECpN+) que não apresentaram metilação da E-caderina nenhuma diferença estatisticamente significativa foi observada entre as taxas de sobrevida livre de doença em cinco e dez anos. Estes resultados sugerem que os CECs com hipermetilação da região promotora do gene da Ecaderina e comprometimento linfonodal (CEC-pN+) provavelmente apresentem um comportamento mais agressivo e menor sobrevida livre de doença se comparado aos carcinomas com metilação desta molécula de adesão, porém sem metástase regional (CV e CEC-pN0).

Com base nos resultados obtidos neste estudo, principalmente nas análises imunohistoquímicas e de biologia molecular, podemos concluir que o carcinoma verrucoso apresenta 
um comportamento clínico e biológico relativo à molécula de adesão celular E-caderina, mais favorável em relação ao carcinoma espinocelular bem diferenciado. Fatores como a presença de invasão de células neoplásicas e metástase regional como observado nos CECs-pN+ não tiveram grande influência no padrão de metilação da E-caderina, mas a presença deste evento epigenético em tumores com baixo potencial invasivo e metastático como o CV sugere que a hipermetilação do gene da E-caderina ocorra precocemente dentro dos mecanismos envolvidos na progressão tumoral.

As ferramentas atualmente utilizadas nas análises de metilação nas neoplasias malignas avaliam esse evento epigenético de forma estática, mas os processos celulares nos tumores são muito mais dinâmicos e estão em constante modificação. Além disso, o uso de técnicas que identifiquem estas alterações genéticas de forma quantitativa poderá nos fornecer no futuro resultados surpreendentes relativos a influência de moléculas como a E-caderina na evolução dos carcinomas espinocelulares de boca. 
7 CONCLUSÕES 


\section{CONCLUSÕES}

Analisando-se as características demográficas, clínicas e microscópicas de dez pacientes com carcinoma verrucoso de boca, verificamos que:

- os pacientes acometidos pelo carcinoma verrucoso eram predominantemente do gênero masculino, raça branca, com idade média de 67,8 anos, tabagistas e etilistas, apresentando no momento do diagnóstico estadiamento clínico inicial;

- o lábio inferior, seguido pela gengiva inferior e palato duro, foram os locais mais acometidos, sendo as lesões, freqüentemente, ulcerovegetantes;

- esvaziamento cervical e a radioterapia e/ou quimioterapia pós-operatória não foram realizadas nestes pacientes com $\mathrm{CV}$;

- recidiva local e a ocorrência de um segundo tumor primário foram detectadas nos pacientes com CV após o tratamento;

- metástase locorregional e a distância não foram observadas;

- morfologicamente, a maioria dos carcinomas verrucosos apresentou tecido epitelial hiperplásico, com discreto e/ou moderado hipercromatismo e com acantose intensa, fendas epiteliais preenchidas por queratina, poucas figuras de mitoses, cristas epiteliais interpapilares largas e longas, padrão de invasão compressivo com membrana basal íntegra e discreto infiltrado inflamatório mononuclear no tecido conjuntivo adjacente;

- embolização vascular e/ou linfática e infiltração dos tecidos neurais, musculares, ósseos e glandulares não foram observados. 
O estudo comparativo dos grupos CV, CEC-pN0 e CEC-pN+, quanto à sobrevida global e livre de doença, expressão imuno-histoquímica e hipermetilação do gene da Ecaderina, revelou:

- a hipermetilação do gene da E-caderina foi estatisticamente semelhante $(p=0,975)$ e superior a 50\% nos três grupos de carcinomas de boca (CV, CEC-pN0 e CEC-pN+);

- nenhuma alteração quanto à hipermetilação do gene da E-caderina em mucosa bucal sem sinais de malignidade foi detectada;

- houve uma diferença estatisticamente significativa $(p=0,011)$, quanto à expressão imunohistoquímica da E-caderina, entre os grupos CV e CEC-pN+;

- entre os grupos CV e CEC-pN0 houve uma diferença sugestiva $(0,096)$ e entre os grupos CEC-pN0 e CEC-pN+ não foi detectada nenhuma correlação $(p=0,315)$, quanto à expressão imuno-histoquímica desta molécula de adesão;

- nenhuma correlação estatisticamente significativa foi obtida entre a expressão imunohistoquímica e a hipermetilação do gene da E-caderina para os carcinomas verrucosos e carcinomas espinocelulares sem comprometimento linfonodal $(\mathrm{p}=0,170)$;

- no grupo CEC-pN+, houve uma associação estatisticamente significativa $(p=0,044)$ entre o perfil de metilação do gene da E-caderina e a expressão imuno-histoquímica desta molécula, no entanto foi oposta à associação descrita na literatura, pois todos os casos que não metilaram apresentaram MBC inferior ou igual a 36,5\%;

- a influência da morfologia tumoral no prognóstico dos pacientes portadores de CV, CECpN0 e CEC-pN+, revelou uma diferença estatisticamente significativa na comparação entre as curvas de sobrevida global $(p=0,012)$; 
- os pacientes com CV apresentaram maiores probabilidades de sobrevida global acumuladas em cinco e dez anos, 87,5\% e 65,6\%, quando comparados aos pacientes dos grupos CEC-pN0 e CEC-pN+;

- quanto à sobrevida livre de doença verificamos que tanto para cinco como dez anos, respectivamente, os valores percentuais do grupo CV (65,6 e 52,4\%) situaram entre o grupo CEC-pN0 (84,8 e 84,8\%), que apresentou os maiores valores, e o grupo CEC-pN+ (57,7 e 48,1\%), sendo que os percentuais de recidiva da lesão no grupo CV (40,0\%) foram superiores ao observado para o grupo CEC-pN0 (20,0\%);

- a comparação das curvas de sobrevida global dos grupos em relação à expressão imunohistoquímica da E-caderina mostrou uma diferença sugestiva $(\mathrm{p}=0,066)$, entre os espécimes que apresentaram MBC inferior ou igual a 36,5\% entretanto, entre as amostras que apresentaram MBC superior a 36,5\% nenhuma diferença estatística $(p=0,184)$ foi encontrada. Tanto para cinco quanto para dez anos, para as duas variáveis categóricas, as taxas de sobrevida do carcinoma verrucoso foram superiores às verificadas nos grupos de carcinomas espinocelulares;

- a comparação das curvas de sobrevida global dos grupos em relação ao perfil de metilação do gene da E-caderina mostrou uma diferença estatisticamente significativa $(p=0,031)$, entre os espécimes que não metilaram, entretanto, entre as amostras que metilaram uma diferença estatística sugestiva $(p=0,072)$ foi encontrada. Tanto para cinco quanto para dez anos, para os dois padrões de metilação, a taxa de sobrevida do carcinoma verrucoso foi superior a verificada nos grupos de carcinomas espinocelulares;

- a probabilidade de sobrevida livre de doença nos grupos de carcinomas quanto à imunomarcação da E-caderina, mostrou-se estatisticamente significativa tanto para os valores superiores a 36,5\% MBC $(\mathrm{p}=0,040)$ quanto para aqueles inferiores ou iguais a 
36,5\% MBC $(p=0,036)$, sendo que nos pacientes dos grupos CV e CEC-pN0 as sobrevidas livres de doença em cinco e dez anos foram próximas, porém, percentualmente, bem maiores quando comparadas àquelas do grupo CEC-pN+;

- em relação à hipermetilação do gene da E-caderina, a sobrevida livre de doença em cinco e dez anos foi semelhante para os grupos CV e CEC-pN0 e apresentou menores valores para o grupo CEC-pN+ sendo a diferença estatística marginal entre os grupos de carcinomas hipermetilados ( $\mathrm{p}=0,062)$; nos carcinomas com ausência de hipermetilação do gene da E-caderina não houve diferença estatística $(p=0,611)$ entre as sobrevidas livres de doença dos três grupos de carcinomas bucais analisados.

Com base nos resultados obtidos neste estudo, principalmente nas análises imunohistoquímicas e de biologia molecular, podemos concluir que o carcinoma verrucoso apresenta um comportamento clínico e biológico relativo à molécula de adesão celular E-caderina, mais favorável em relação ao carcinoma espinocelular bem diferenciado. Fatores como a presença de invasão de células neoplásicas e metástase regional como observado nos CECs-pN+ não tiveram grande influência no padrão de metilação da E-caderina, mas a presença deste evento epigenético em tumores com baixo potencial invasivo e metastático como o CV sugere que a hipermetilação do gene da E-caderina ocorra precocemente dentro dos mecanismos envolvidos na progressão tumoral. 
ANEXX 
ANEXO - Ficha utilizada para a coleta dos dados clínicos e microscópicos relativos aos pacientes com carcinoma verrucoso e carcinoma espinocelular bem diferenciado de boca

\section{Registro da coleta de dados}

Faculdade de Odontologia de Bauru / USP

Departamento de Estomatologia - Área de Patologia

Fundação Antônio Prudente / Hospital do Câncer

Departamento de Cirurgia de Cabeça e Pescoço e Otorrinolaringologia

Departamento de Anatomia Patológica

\section{Carcinoma verrucoso de boca: análise das características clínicas, microscópicas, da expressão imuno-histoquímica e hipermetilação do gene da E-caderina}

CD Renato Vieira de Moraes; Profa. Dra. Denise Tostes Oliveira; Prof. Dr. Luiz Paulo Kowalski;

Prof. Dr. Gilles Landman

Identificação e dados demográficos:

1. Número no estudo:

2. RGH:

3. Idade: anos

4. Gênero: $\square$ 1-masculino $\square$ 2-feminino

5. Raça: $\square$ 1-branca $\square$ 2-amarela $\square$ 3-negra $\square$ 4-outra

\section{História clínica:}

6. Tempo de história: meses (999 se desconhecido)

7. Queixas: $\square$ 1-somente do t. primário $\square$ 2-somente da metástase $\square$ 3-ambos $\square$ 9-desc.

8. Biópsia prévia: $\square$ 0-não $\square$ 1-primário $\square$ 2-linfonodo $\square$ 3-ambos

9. História familiar de câncer: $\square$ 0-não $\square$ 1-pais $\square$ 2-irmãos $\square$ 3-outros parentes $\square$ 9-desc.

10. Tabagismo: $\square$ 0-não $\square$ 1-+ $\square$ 2-++ $\square$ 3- +++ $\square$ 4- ++++ $\square$ 9-desc.

11. Tipo de tabaco: $\square$ cigarro de papel $\square$ cigarro de palha $\square$ cachimbo $\square$ charuto $\square$ fumo mascado

12. Etilismo: $\square$ 0-não $\square$ 1-+ $\square$ 2-++ $\square$ 3-+++ $\square$ 4- ++++ $\square$ 9-desc.

13. Lesões bucais prévias: $\square$ 1-sim $\square$ 2-não $\square$ 9-desc. Se sim, quais?

Loco-regional:

14. Local de tumor: $\square$ 1-lábio superior $\square$ 2- lábio inferior $\square$ 3-língua $\square$ 4-assoalho

$\square$ 5-gengiva superior $\square$ 6-palato duro $\square$ 7-palato mole $\square$ 8- gengiva inferior

$\square$ 9-mucosa jugal $\square$ 10- área retromolar

15. Extensão do tumor: $\square$ 0-não $\square$ 1-língua $\square$ 2-assoalho $\square$ 3-gengiva $\square$ 4-retromolar

5-lábio superior $\square$ 6-lábio inferior $\square$ 7-mucosa jugal $\square$ 8-palato




$$
\text { 9-loja amigdaliana } \square \text { 10- outros }
$$

16. Tipo de lesão: $\square$ 1-úlcero-vegetante $\square$ 2-úlcero-infiltrativa $\square$ 3-outra

17. Diâmetro aproximado da lesão: $\mathrm{cm}$

18. Nível de linfonodos ipsilaterais N+ clinicamente: $\square$ 0-não $\square$ 1-I $\square$ 2-II $\square$ 3-III $\square$ 4-IV $\square$ 5-V

19. Diâmetro do maior linfonodo ipsi+: cm $(0$ se $\mathrm{N}-)$

20. Nível de linfonodos contralaterais N+ clinicamente: $\square$ 0-não $\square$ 1-I $\square$ 2-II $\square$ 3-III $\square$ 4-IV $\square$ 5-V

21. Diâmetro do maior linfonodo cont. +: cm (0 se $\mathrm{N}-)$

22. Mobilidade dos linfonodos: $\square$ 1-móveis $\square$ 2-diminuição de mobilidade $\square$ 3-fix. superf.

$$
\square \text { 4-fix. profunda }
$$

23. Estádio T (atualizar UICC 02): $\square$ 1-T1 $\square$ 2-T2 $\square$ 3-T3 $\square$ 4-T4 $\square$ 9-Tx

24. Estádio N (atualizar UICC 02): $\square$ 0-N0 $\square$ 1-N1 $\square$ 2-N2a $\square$ 3-N2b $\square$ 4-N2c $\square$ 5-N3 $\square$ 9-Nx

\section{Cirurgia:}

25. Data da cirurgia:

26. Cir. Tumor primário: $\square$ 1-glossec. parcial $\square$ 2-hemiglossec. $\square$ pelve glossec.

$$
\begin{aligned}
& \square \text { 4-pelve (gl) mand. marg. (Pull) } \square \text { 5-pelve (gl) mand. sec. (com) } \\
& \square \text { 6-retrom. } \square \text { 7-retrom.ampliada } \square \text { resecção de lábio }
\end{aligned}
$$

27. Esvaz. cervical ipsilateral: $\square$ 0-não $\square$ 1-ESOH $\square$ 2-ECR $\square$ 3-ECRM (XI) $\square$ 4-ECRM (XI+VJ)

28. Esvaz. cervical contral. (simult.): $\square$ 1-não $\square$ 2-ESOH $\square$ 3-ECRM (XI) $\square$ 4-ECRM (XI+VJ)

29. Esvaz. cervical: $\square$ 0-não $\square$ 1-monobloco $\square$ 2-dibloco

30. Ampliação de esvaz. cervical: $\square$ 0-não $\square$ 1-pele $\square$ 2-carótida $\square$ 3-hipoglosso $\square$ 4-vago 5-outro

31. Data da alta hospitalar:

\section{Radioterapia pós-operatória:}

32. Data do início ___________ (0/0/0 se não fez)

33. Aparelho: $\square$ 0-não fez $\square$ 1-ortov. $\square$ 2-cesium $\square$ 3-cobalto $\square$ 4-AL

34. Dose campo cérvico-facial: Gy (0 se não fez)

35. Dose em fossa ipsilateral: Gy (0 se não fez)

36. Dose em fossa contralateral: Gy (0 se não fez ou irrad. unilateral)

37. Data do final:

\section{Anatomopatológico da peça da cirurgia inicial:}

38. Número do AP:

39. Histologia do t. primário: $\square$ 1-CEC I $\square$ 2-CEC II $\square$ 3-CEC III $\square$ 4-CEC SOE

40. Hipercromatismo: $\square$ 0-ausente $\square$ 1-discreto $\square$ 2-moderado $\square$ 3-intenso

41. Pleomorfismo: $\square$ 0-ausente $\square$ 1-discreto $\square$ 2-moderado $\square$ 3-intenso

42. Mitoses atípicas: $\square$ 0-ausente $\square$ 1-discreto $\square$ 2-moderado $\square$ 3-intenso

43. Queratinização: $\square$ 0-ausente $\square$ 1-discreto $\square$ 2-moderado $\square$ 3-intenso

44. Disqueratose: $\square$ 0-ausente $\square$ 1-discreto $\square$ 2-moderado $\square$ 3-intenso 
45. Membrana basal: $\square$ 0-íntegra $\square$ 1-descontínua $\square$ 3-rompida

46. Acantose: $\square$ 0-ausente $\square$ 1-discreto $\square$ 2-moderado $\square$ 3-intenso

47. Padrão de invasão tumoral : $\square$ 1-compressivo $\square$ 2-cordões grossos $\square$ 3-cordões finos $\square$ 4- células isoladas

48. Distribuição do infiltrado inflamatório: $\square$ 1-focal $\square$ 2-difusa

49. Localização do infiltrado inflamatório: $\square$ 1- epitélio $\square$ 2- estroma $\square$ 3-ambos

50. Infiltrado inflamatório PMN: $\square$ 0-ausente $\square$ 1-discreto $\square$ 2-moderado $\square$ 3-intenso

51. Infiltrado inflamatório MN: $\square$ 0-ausente $\square$ 1-discreto $\square$ 2-moderado $\square$ 3-intenso

52. Infiltrado inflamatório eosinofílico: $\square$ 0-ausente $\square$ 1-discreto $\square$ 2-moderado $\square$ 3-intenso

53. Embolização vascular: $\square$ 0-não $\square$ 1-linfática $\square$ 2-sangüínea $\square$ 3-ambas $\square$ 4-"presente" $\square$ 9-ign.

54. Infiltração perineural: $\square$ 0-não $\square$ 1-presente $\square$ 9-ignorado

55. Infiltração muscular: $\square$ 0-não $\square$ 1-presente $\square$ 9-ignorado

56. Infiltração óssea: $\square$ 0-não $\square$ 1-presente $\square$ 9-ignorado

57. Infiltração de glândulas salivares: $\square$ 0-não $\square$ 1-presente $\square$ 9-ignorado

58. Margens: $\square$ 0-livres $\square$ 1-exíguas $\square$ 2-comprometidas $\square$ 9-ign.

59. Espessura:__ mm (999 se não relatado)

60. Número de linfonodos comprometidos ipsilaterais: (99 se não esv.)

61. Número de linfonodos dissecados ipslaterais: (999 se não esv.)

62. Níveis de linfonodos comprometidos ipsi.: $\square$ 0-N $\square$ 1-I $\square$ 2-II $\square$ 3-III $\square$ 4-IV $\square$ 5-V

$\square$ 9-ign./não esv.

63. Número de linfonodos dissecados contralaterais: (999 se não esv.)

64. Níveis de linfonodos comprometidos cont.: $\square$ 0-N $\square$ 1-I $\square$ 2-II $\square$ 3-III $\square$ 4-IV $\square$ 5-V

9-ign./não esv.

\section{Evolução:}

65. Data da primeira recidiva:

66. Locais de recidiva: $\square$

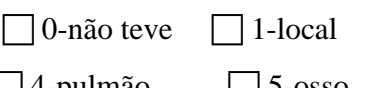

4-pulmão 5-osso $\square$ 2-pescoço ipsi

$\square$ 6-fígado 3-pescoço contra

$\square$ 7-outra à distância

9-ignorado (perdido de vista assintomático $<5$ anos)

67. Data do diagnóstico do segundo tumor primário: (0/0/0 se não teve)

68. Local do segundo tumor primário: CID-O (0 se não teve)

69. Data da última informação objetiva de seguimento:

70. Situação na última informação de seguimento: $\square$ 1-vivo 000 $\square$ 2-vivo com CA $\square$ 3-morte pós-op. $\square$ 4-MOCA $\square$-Moass
$\square$ 6-perdido de vista (definição: para pacientes com menos de
5 anos de seguimento todos os que deixaram de retornar por um
período igual ao dobro estipulado. Pacientes assintomáticos
perdidos após 5 anos devem ser classificados como vivos 000) OBS: Para pacientes perdidos de vista: anotar nome, endereço e telefone. Entregar o prontuário aos responsáveis pela convocação de pacientes esta lista diariamente. 
REFERÊTCIAS BIBLIOGRÁFICAS 


\section{REFERÊNCIAS BIBLIOGRÁFICAS*}

1. ACKERMAN, L.V. Verrucous carcinoma of the oral cavity. Surgery, v.23, p. 670$8,1948$.

2. ADLER-STORTHZ, K. et al. Human papillomavirus Type 2 DNA in oral verrucous carcinoma. J Oral Pathol, v.15, n.9, p.472-5, Oct. 1986.

3. ALBELDA, S.M. Role of integrins and other cell adhesion molecules in tumor progression and metastasis. Lab Invest, v.68, n.1, p.4-17, Jan. 1993.

4. APLIN, A.E. et al. Signal transduction and signal modulation by cell adhesion receptors: the role of integrins, cadherins, immunoglobulin-cell adhesion molecules, and selectins. Pharmacol Rev, v.50, n.2, p.197-263, June 1998.

5. BAYLIN, S.B.; HERMAN, J.G. DNA hypermethylation in tumorigenesis epigenetics joins genetics. Trends Genet, v.16, n.4, p.168-74, Apr. 2000.

6. BEAVON, I.R.G. The E-cadherin-catenin complex in tumour metastasis: structure, function and regulation. Eur J Cancer, v.36, n.13, p.1607-20, Aug. 2000.

7. BOUQUOT, J.E. Oral verrucous carcinoma: incidence in two US populations.

Oral Surg Oral Med Oral Pathol Oral Radiol Endod, v.86, n.3, p.318-24, Sept. 1998.

\footnotetext{
* Normas recomendadas para o uso no âmbito da Universidade de São Paulo, com base no documento "Referências Bibliográficas: exemplos" emanado do Conselho Supervisor do Sistema de Bibliotecas da USP, em reunião de 20 de setembro de 1990 .
} 
8. BROOKS, J.J.; ENTERLINE, H.T.; APONTE, G.E. The final diagnosis of President Cleveland's lesion. Trans Stud Coll Physicians Phila, v.2, n.1, p.125, Mar.1980.

9. BRYNE, M. Is the invasive front of an oral carcinoma the most important area for prognostication? Oral Dis, v.4, n.2, p.70-7, June 1998.

10. CASTRO, A.L. de et al. Carcinoma verrucoso. Rev Cient UNOESTE, v.11, p.75$81,1991$.

11. CAWSON, R.A. et al. Lucas's pathology of tumours of the oral tissues. 5.ed. London, Churchill Livingstone, 1998.

12. CHAGIN, A.L. Factores de riesgo etiopatogenicos del carcinoma verrugoso en cavidad bucal. Acta Odontol Venez, v.38, n.2, p.9-14, June 2000.

13. CHAMMAS, R.; VILLA, L.L. Aspectos celulares e moleculares da progressão tumoral. Acta Oncol Bras, v.1,2,3, n.13, p.17-27, jan / dez 1993.

14. CHANG, H.W. et al. Loss of E-cadherin expression resulting from promoter hypermethylation in oral tongue carcinoma and its prognostic significance. Cancer, v.94, n.2, p.386-92, Jan. 2002.

15. CHEN, Q. et al. Promoter methylation regulates cadherin switching in squamous cell carcinoma. Biochem Biophys Res Commun, v.315, n.4, p.850-6, Mar. 2004.

16. CHOW, V. et al. A comparative study of the clinicopathological significance of Ecadherin and catenins $(\alpha, \beta, \gamma)$ expression in the surgical management of oral tongue carcinoma. J Cancer Res Clin Oncol, v.127, n.1, p.59-63, Jan. 2001. 
17. CHRISTOFORI, G.; SEMB, H. The role of the cell-adhesion molecule E-cadherin as a tumour-suppressor gene. Trends Biochem Sci, v.24, n.2, p.73-6, Feb. 1999.

18. COHEN, B.; POSWILLO, D.E.; WOODS, D.A. The effects of exposure to chewing tobacco on the oral mucosa of monkey and man. A histological and ultrastructural study. Ann R Coll Surg Engl, v.48, n.5, p.255-73, May 1971.

19. CONACCI-SORRELL, M. et al. Autoregulation of E-cadherin expression by cadherin-cadherin interactions: the roles of $\beta$-catenin signaling, Slug, and MAPK. J Cell Biol, v.163, n.4, p.847-57, Nov. 2003.

20. CONSOLARO, A.; TAVEIRA, L.A.A.; RADOS, P.V. Carcinoma verrucoso: revisão da literatura e apresentação de um caso. Rev Fac Odontol Porto Alegre, v.33, p.16-20, 1992.

21. CORTEZZI, S.S. Papilomavírus humano e polimorfismo do gene TP53 no carcinoma espinocelular de cabeça e pescoço. São José do Rio Preto, 2002. 78p. Dissertação (Mestrado) - Universidade Estadual Paulista, Instituto de Biociências, Letras e Ciências Exatas.

22. COSTA, F.F. Identificação de regiões diferencialmente metiladas em câncer de mama através da técnica AP - PCR Sensível à Metilação (MSAP-PCR). São Paulo, 2004. 111p. Tese (Doutorado) - Fundação Antônio Prudente, Hospital do Câncer A. C. Camargo.

23. COSTELlO, J.F.; PLASS, C. Methylation matters. J Med Genet, v.38, n.5, p.285303, May 2001. 
24. DEMIAN, S.D.E.; BUSHKIN, F.L.; ECHEVARRIA, R.A. Perineural invasion and anaplastic transformation of verrucous carcinoma. Cancer, v.32, n.2, p.395401, Aug. 1973.

25. EISENBERG, E.; ROSENBERG, B.; KRUTCHKOFF, D.J. Verrucous carcinoma: a possible viral pathogenesis. Oral Surg Oral Med Oral Pathol Oral Radiol Endod, v.59, n.1, p.52-7, Jan. 1985.

26. ESTELLER, M. Epigenetic lesions causing genetic lesions in human cancer: promoter hypermethylation of DNA repair genes. Eur J Cancer, v.36, n.18, p.2294-300, Dec. 2000.

27. ESTELLER, M. et al. Hypermethylation-associated inactivation of $\mathrm{p} 14^{\mathrm{ARF}}$ is independent of p16 ${ }^{\mathrm{INK} 4 \mathrm{a}}$ methylation and p53 mutational status. Cancer Res, v. 60, n.1, p.129-33, Jan. 2000.

28. ESTELLER, M. et al. A gene hypermethylation profile of human cancer. Cancer Res, v.61, n.8, p.3225-9, Apr. 2001.

29. FEINBERG, A.P. Cancer epigenetics takes center stage. Proc Natl Acad Sci USA, v.98, n.2, p.392-4, Jan. 2001.

30. FERLITO, A.; RINALDO, A.; MANNARÀ, G.M. Is primary radiotherapy an appropriate option for the treatment of verrucous carcinoma of the head and neck? J Laryngol Otol, v.112, n.2, p.132-9, Feb. 1998.

31. FERLITO, A. et al. Papillary squamous cell carcinoma versus verrucous squamous cell carcinoma of the head and neck. Ann Otol Rhinol Laryngol, v.108, n.3, p.318-22, Mar. 1999.

32. FIGUEIREDO, M.A.Z. et al. Carcinoma verrucoso. Apresentação de casos. Rev Odonto Cienc, v.2, p.63-74, 1991. 
33. FONG, K.M.; ZIMMERMAN, P.V.; SMITH, P.J. Correlation of loss of heterozygosity at $11 \mathrm{p}$ with tumour progression and survival in non-small cell lung cancer. Genes Chromosomes Cancer, v.10, n.3, p.183-9, July 1994.

34. FRIEDELL, H.L.; ROSENTHAL, L.M. The etiologic role of chewing tobacco in cancer of the mouth. J A M A, v.116, p.2130-5, 1941.

35. GARINIS, G.A. et al. DNA hypermethylation: when tumour suppressor genes go silent. Hum Genet, v.111, n.2, p.115-27, Aug. 2002.

36. GO, J.H.; OH, Y.L.; KO, Y.H. Hybrid verrucous squamous cell carcinoma of sinonasal tract: a case report. J Korean Med Sci, v.13, n.6, p.662-4, Dec. 1998.

37. GOLDENBERG, D. et al. Intraoperative molecular margin analysis in head and neck cancer. Arch Otolaryngol Head Neck Surg, v.130, n.1, p.39-44, Jan. 2004.

38. GRAFF, J.R. et al. Methylation patterns of the E-cadherin 5' CpG island are unstable and reflect the dynamic, heterogeneous loss of E-cadherin expression during metastatic progression. J Biol Chem, v.275, n.4, p.2727-32, Jan. 2000.

39. HAJRA, K.M.; FEARON, E.R. Cadherin and catenin alterations in human cancer. Genes Chromosomes Cancer, v.34, n.3, p.255-68, July 2002.

40. HALL S.F. et al. Using TNM staging to predict survival in patients with squamous cell carcinoma of head and neck. Head Neck, v.21, n.1, p.30-8, Jan. 1999.

41. HASEGAWA, M. et al. Patterns of gene promoter methylation in squamous cell cancer of the head and neck. Oncogene, v.21, n.27, p.4231-6, June 2002.

42. HERMAN, J.G. et al. Methylation-specific PCR: a novel PCR assay for methylation status of CpG island. Proc Natl Acad Sci USA, v.93, n.18, p. 9821-6, Sept. 1996. 
43. HIROHASHI, S.; KANAI, Y. Cell adhesion system and human cancer morphogenesis. Cancer Sci, v.94, n.7, p.575-81, July 2003.

44. HUANG, M.J. et al. The correlation between $\mathrm{CpG}$ methylation and protein expression of P16 in oral squamous cell carcinoma. Int J Mol Med, v.10, n.5, p.551-4, Nov. 2002.

45. ISHIYAMA, A. et al. Papillary squamous neoplasms of the head and neck. Laryngoscope, v.104, n.12, p.1446-52, Dec. 1994.

46. JACOBSON, S.; SHEAR, M. Verrucous carcinoma of the mouth. J Oral Pathol, v.1, n.2, p.66-75, 1972.

47. JONES, P.A.; LAIRD, P.W. Cancer epigenetics comes of age. Nat Genet, v.21, n.2, p.163-7, Feb. 1999.

48. JYOTHIRMAYI, R. et al. Radiotherapy in the treatment of verrucous carcinoma of the oral cavity. Oral Oncol, v.33, n.2, p.124-8, Mar. 1997.

49. KANTAK, S.S.; KRAMER, R.H. E-cadherin regulates anchorage-independent growth and survival in oral squamous cell carcinoma cells. J Biol Chem, v.273, n.27, p.16953-61, July 1998.

50. KAUGARS, G.E.; MEHAILESCU, W.L.; GUNSOLLEY, J.C. Smokeless tobacco use and oral epithelial dysplasia. Cancer, v.64, n.7, p.1527-30, Oct. 1989.

51. KAUGARS, G.E. et al. The prevalence of oral lesions in smokeless tobacco users and an evaluation of risk factors. Cancer, v.70, n.11, p.2579-85, Dec. 1992.

52. KAUGARS, G.E. et al. Oral verrucous carcinoma. Oral Surg Oral Med Oral Pathol Oral Radiol Endod, v.87, n.3, p.268-9, Mar. 1999.

53. KNUDSON JR., A.G. Mutation and cancer: statistical study of retinoblastoma. Proc Natl Acad Sci USA, v.68, n.4, p.820-3, Apr. 1971. 
54. KOCH, B.B. et al. National survey of head and neck verrucous carcinoma. Cancer, v.92, n.1, p.110-20, July 2001.

55. KOWALSKI, L.P. et al. Factors influencing contralateral lymph node metastasis from oral carcinoma. Head Neck, v.21, n.2, p.104-10, Mar. 1999.

56. KRAUS, F.; PEREZ-MESA, C. Verrucous carcinoma - clinical and pathologic study of 105 cases involving oral cavity, larynx and genitalia. Cancer, v.19, n.1, p.26-38, Jan. 1966.

57. KUDO, Y. et al. Invasion and metastasis of oral cancer cells require methylation of E-cadherin and/or degradation of membranous $\beta$-catenin. Clin Cancer Res, v.10, n.16, p.5455-63, Aug. 2004.

58. LINK, J.O.; KAUGARS, G.E.; BURNS, J.C. Comparison of oral carcinomas in smokeless tobacco users and nonusers. J Oral Maxillofac Surg, v.50, n.5, p.452-5, May 1992.

59. LÜBBE, J. et al. HPV-11 and HPV-16 associated oral verrucous carcinoma. Dermatology, v.192, n.3, p.217-21, 1996.

60. LUNDGREN, J.A.V. et al. Verrucous carcinoma (Ackerman's tumor) of the larynx: diagnostic and therapeutic considerations. Head Neck Surg, v.9, n.1, p.19-26, Sept./Oct. 1986.

61. MCCOY, J.M.; WALDRON, C.A. Verrucous carcinoma of the oral cavity. A review of forty-nine cases. Oral Surg Oral Med Oral Pathol Oral Radiol Endod, v.52, n.6, p.623-9, Dec. 1981.

62. MATTIJSSEN, V. et al. E-cadherin expression in head and neck squamous cell carcinoma is associated with clinical outcome. Int J Cancer, v.55, n.4, p.580-5, Oct. 1993. 
63. MIRBOD, S.M.; AHING, S.I. Tobacco-associated lesions of the oral cavity: Part II. Malignant lesions. J Can Dent Assoc, v.66, n.6, p.308-11, June 2000.

64. NAKAYAMA, S. et al. The E-cadherin gene is silenced by CpG methylation in human oral squamous cell carcinomas. Int J Cancer, v.93, n.5, p.667-73, Sept. 2001.

65. NIPARKO, J.K.; RUBINSTEIN, M.I.; MCCLATCHEY, K.D. Invasive squamous cell carcinoma within verrucous carcinoma. J Otolaryngol, v.7, n.1, p.38-40, Feb. 1988.

66. NOBLE-TOPHAM, S.E. et al. Detection and typing of human papillomavirus in verrucous carcinoma of the oral cavity using the polymerase chain reaction. Arch Otolaryngol Head Neck Surg, v.119, p.1299-304, Dec. 1993.

67. OKAMOTO, M. et al. Prediction of delayed neck metastasis in patients with stage I/II squamous cell carcinoma of the tongue. J Oral Pathol Med, v.31, n.4, p.227-33, Apr. 2002.

68. PINDBORG, J.J. et al. Histological typing of cancer and precancer of the oral mucosa. 2.ed. Berlin, Springer Verlag, 1997.

69. POMATTO, E. et al. Verrucous carcinoma of the oral cavity. Personal experience with combined chemo-surgical-treatment. Minerva Chir, v.48, n.5, p.213-9, Mar. 1993.

70. RAJENDRAN, R. et al. Ackerman's tumour (Verrucous carcinoma) of the oral cavity: a clinico-epidemiologic study of 426 cases. Aust Dent J, v.33, n.4, p.295-8, Aug. 1988. 
71. RAJENDRAN, R. et al. Ackerman's tumour (Verrucous carcinoma) of the oral cavity: a histopathologic study of 426 cases. Singapore Dent J, v.14, n.1, p.4853, Dec. 1989.

72. SAITO, T.; NAKAJIMAT, T.; MOGI, K. Immunohistochemical analysis of cell cycle-associated proteins p16, pRb, p53, p27 and Ki-67 in oral cancer and precancer with special reference to verrucous carcinomas. J Oral Pathol Med, v.28, n.5, p.226-32, May 1999.

73. SAKAKI, T. et al. Correlation of E- and P-cadherin expression with differentiation grade and mode of invasion in gingival carcinoma. Pathol Int, v.44, n.4, p.2806, Apr. 1994.

74. SANGUINETTI, C.J.; DIAS, N.E.; SIMPSON, A.J. Rapid silver staining and recovery of PCR products Septarated on polyacrylamide gels. Biotechniques, v.17, n.5, p.914-21, Nov. 1994.

75. SANTANA FILHO, M.; ROVANI, G. Avaliação quantitativa das células de Langerhans no carcinoma verrucoso e no epitélio normal adjacente. Rev Pós Grad, v.7, n.3, p.225-9, July/set. 2000.

76. SCHIPPER, J.H. et al. E-cadherin expression in squamous cell carcinomas of head and neck: inverse correlation with tumor dedifferentiation and lymph node metastasis. Cancer Res, v.51, n.23, p.6328-37, Dec. 1991.

77. SHINOHARA, M. et al. Immunohistochemical study of desmossomes in oral squamous cell carcinoma: correlation with cytokeratin and E-cadherin staining, and with tumour bahaviour. J Pathol, v.184, n.4, p.369-81, Apr. 1998.

78. SINGAL, R.; GINDER, G.D. DNA methylation. Blood, v.93, n.12, p.4059-70, June 1999. 
79. SLAUS, N.P. Tumor suppressor gene E-cadherin and its role in normal and malignant cells. Cancer Cell Int, v.3, n.1, p.17-23, Oct. 2003.

80. SMIRAGLIA, D.J.; SMITH, L.T.; LANG, J.C. Differential targets of CpG island hypermethylation in primary and metastatic head and neck squamous cell carcinoma (HNSCC). J Med Genet, v.40, n.1, p.25-33, Jan. 2003.

81. SMITH, M.E.F.; PIGNATELLI, M. The molecular histology of neoplasia: the role of the cadherin/catenin complex. Histopathology, v.31, n.2, p.107-11, Aug. 1997.

82. SPIRO, R. Verrucous carcinoma, then and now. Am J Surg, v.176, n.5, p.393-7, Nov. 1998.

83. STATACORP 2001. Stata statistical software: release 7.0. College Station, Stata Corporation, 2001.

84. SUNDSTRÖM, B.; MÖRNSTAD, H.; AXÉLL, T. Oral carcinomas associated with snuff dipping. Some clinical and histological characteristics of 23 tumours in Swedish males. J Oral Pathol, v.11, n.3, p.245-51, June 1982.

85. TAKEICHI, M. Cadherin cell adhesion receptors as a morphogenetic regulator. Science, v.251, n.5000, p.1451-5, Mar. 1991.

86. TANAKA, N. et al. Expression of E-cadherin, $\alpha$-catenin, and $\beta$-catenin in the process of lymph node metastasis in oral squamous cell carcinoma. $\mathbf{B r} \mathbf{J}$ Cancer, v.89, n.3, p.557-63, Aug. 2003.

87. TANG, Z.G.; ZOU, P.; XIE, X.L. Expression of E-cadherin gene protein in oral verrucous carcinoma. Hunan Yi Ke Da Xue Xue Bao, v.28, n.3, p.206-8, June 2003. 
88. TIAN, Z.; GUO, W.; ZHANG, W.G. The expression of E-cadherin in oral cancer with different biological behavior. Shanghai Kou Qiang Yi Xue, v.11, n.4, p.350-2, Dec. 2002.

89. TOYOTA, M.; ISSA, J.P.J. CpG island methylator phenotypes in aging and cancer. Semin Cancer Biol, v.9, n.5, p.349-57, Oct. 1999.

90. VIDYASAGAR, M.S. et al. Radiotherapy and verrucous carcinoma of the oral cavity - a study of 107 cases. Acta Oncol, v.31, n.1, p.43-7, 1992.

91. VISWANATHAN, M.; TSUCHIDA, N.; SHANMUGAM, G. Promoter hypermethylation profile of tumor-associated genes p16, p15, hMLH1, MGMT and E-cadherin in oral squamous cell carcinoma. Int J Cancer, v.105, n.1, p.41-6, May 2003.

92. WAJED, S.A.; LAIRD, P.W.; DEMEESTER, T.R. DNA methylation: an alternative pathway to cancer. Ann Surg, v.234, n.1, p.10-20, July 2001.

93. WALSH, L.J. et al. The role of adhesion molecules in oral cancer. Aust Dent J, v.41, n.2, p.80-2, Apr. 1996.

94. WHEELOCK, M.J.; JOHNSON, K.R. Cadherins as modulators of cellular phenotype. Annu Rev Cell Dev Biol, v.19, p.207-35, 2003.

95. WIJNHOVEN, B.P.L.; DINJENS, W.N.M.; PIGNATELLI, M. E-cadherin-catenin cell-cell adhesion complex and human cancer. Br J Surg, v.87, n.8, p.9921005, Aug. 2000.

96. YAMADA, K. et al. The relationship between E-cadherin expression, clinical stage and tumour differentiation in oral squamous cell carcinoma. Oral Dis, v.3, n.2, p.82-5, June 1997. 
97. YEH, K.T. et al. The correlation between $\mathrm{CpG}$ methylation on promoter and protein expression of E-cadherin in oral squamous cell carcinoma. Anticancer Res, v.22, n.6C, p.3971-5, Nov./Dec. 2002.

98. YOKOYAMA, K. et al. Reverse correlation of E-cadherin and snail expression in oral squamous cell carcinoma cells in vitro. Oral Oncol, v.37, n.1, p.65-71, Jan. 2001.

99. YOSHIDA-NORO, C.; SUZUKI, N.; TAKEICHI, M. Molecular nature of the calcium-dependent cell-cell adhesion system im mouse teratocarcinoma and embryonic cells studied with a monoclonal antibody. Dev Biol, v.101, n.1, p.19-27, Jan. 1984.

100. YOSHIMURA, Y. et al. Treatment modalities for oral verrucous carcinomas and their outcomes: contribution of radiotherapy and chemotherapy. Int J Clin Oncol, v.6, n.4, p.192-200, Aug. 2001.

101. ZIOBER, B.L.; SILVERMAN, S.S.; KRAMER, R.H. Adhesive mechanisms regulating invasion and metastasis in oral cancer. Crit Rev Oral Biol Med, v.12, n.6, p.499-510, 2001.

102. ZÖCHBAUER-MÜLLER, S. et al. Aberrant promoter methylation of the multiple genes in non-small cell lung cancer. Cancer Res, v.61, n.1, p.249-55, Jan. 2001. 
ABSTRACT 


\section{Oral verrucous carcinoma: clinicopathologic study, immunohistochemical expression and hypermethylation of E-cadherin gene analyses}

Verrucous carcinoma (VC), is considered a variant of well differentiated squamous cell carcinoma, that is characterized by its low aggressiveness and good prognostic and arises most frequently in the larynx and oral cavity. A total of 1613 cases of surgically excised primary oral squamous cell carcinoma from the files of Otohinolaryngology, Head and Neck Surgery, and Pathology Departments of the A.C. Camargo Cancer Hospital, from 1980 to 2000, were retrospectively reviewed. Ten cases of CVs were identified and analyzed as for the gender, age, race, tobacco and alcohol abuse, localization, stage by the TNM-UICC, treatment, lymph nodes involvement, local and cervical recurrences, distant metastasis and second primary tumors. In addition, we investigated the immunohistochemical expression of the Ecadherin and the promoter region hypermethylation of the E-cadherin gene of VCs comparing with oral well differentiated squamous cell carcinoma without (SCC-pN0) and with (SCC$\mathrm{pN}+$ ) lymph nodes involvement. The 5 and 10 -year survival rates were calculated by KaplanMeyer method. The results demonstrated a predilection of VCs for patients of the masculine gender, with positive tobacco and alcohol history, with age older than 67 years and arise predominantly in the inferior lip. The clinical history was longer than 16 months and no patient with VC was submitted the radiotherapy and/or chemotherapy postoperative. The histopathologic analysis showed a heavily keratinized lesion with compressive invasion pattern, little atypia and free surgical margins. In comparison with SCC-pN0 and SCC-pN+, verrucous carcinoma showed a higher immunohistochemical expression of the E-cadherin score $(p=0,016)$. More than $50 \%$ of the tumors showed the hypermethylation of the Ecadherin gene and no statistically significant differences $(p=0,975)$ were found among VC, SCC-pN0 and SCC-pN+ groups. Verrucous carcinoma of the oral cavity had significantly better 5-year and 10-year overall survival rates than the well differentiated squamous cell carcinomas $(p=0,012)$. These results permit to conclude that the oral verrucous carcinoma presents more favorable clinical and biological behavior related to the immunohistochemical expression of the E-cadherin when compared with well differentiated squamous cell carcinoma. The presence of the hypermethylation of the E-cadherin gene in the malignant tumors with lower potential invasive and metastatic, such as VC, suggests that this epigenetic event happens early in the mechanisms involved in the tumoral progression. 